\title{
Biosynthesis, Quantification and Genetic Diseases of the Smallest Signaling Thiol Metabolite: Hydrogen Sulfide
}

\author{
Joanna Myszkowska $^{1}$, Ilia Derevenkov ${ }^{2}\left(\mathbb{D}\right.$, Sergei V. Makarov ${ }^{2}$, Ute Spiekerkoetter ${ }^{3}\left(\mathbb{D}\right.$ and Luciana Hannibal ${ }^{1, *(1)}$ \\ 1 Laboratory of Clinical Biochemistry and Metabolism, Department of General Pediatrics, Adolescent Medicine \\ and Neonatology, Medical Center, Faculty of Medicine, University of Freiburg, 79106 Freiburg, Germany; \\ joanna.myszkowska@uniklinik-freiburg.de \\ 2 Department of Food Chemistry, Ivanovo State University of Chemistry and Technology, 153000 Ivanovo, \\ Russia; derevenkov@gmail.com (I.D.); makarov@isuct.ru (S.V.M.) \\ 3 Department of General Pediatrics, Adolescent Medicine and Neonatology, Medical Center, Faculty of \\ Medicine, University of Freiburg, 79106 Freiburg, Germany; ute.spiekerkoetter@uniklinik-freiburg.de \\ * Correspondence: luciana.hannibal@uniklinik-freiburg.de
}

check for

updates

Citation: Myszkowska, J.; Derevenkov, I.; Makarov, S.V.; Spiekerkoetter, U.; Hannibal, L. Biosynthesis, Quantification and Genetic Diseases of the Smallest Signaling Thiol Metabolite: Hydrogen Sulfide. Antioxidants 2021, 10, 1065. https://doi.org/10.3390/ antiox10071065

Academic Editors: João Vicente and Alessandro Giuffré

Received: 19 May 2021

Accepted: 24 June 2021

Published: 1 July 2021

Publisher's Note: MDPI stays neutral with regard to jurisdictional claims in published maps and institutional affiliations.

Copyright: (c) 2021 by the authors. Licensee MDPI, Basel, Switzerland. This article is an open access article distributed under the terms and conditions of the Creative Commons Attribution (CC BY) license (https:// creativecommons.org/licenses/by/ $4.0 /)$.
Abstract: Hydrogen sulfide $\left(\mathrm{H}_{2} \mathrm{~S}\right)$ is a gasotransmitter and the smallest signaling thiol metabolite with important roles in human health. The turnover of $\mathrm{H}_{2} \mathrm{~S}$ in humans is mainly governed by enzymes of sulfur amino acid metabolism and also by the microbiome. As is the case with other small signaling molecules, disease-promoting effects of $\mathrm{H}_{2} \mathrm{~S}$ largely depend on its concentration and compartmentalization. Genetic defects that impair the biogenesis and catabolism of $\mathrm{H}_{2} \mathrm{~S}$ have been described; however, a gap in knowledge remains concerning physiological steady-state concentrations of $\mathrm{H}_{2} \mathrm{~S}$ and their direct clinical implications. The small size and considerable reactivity of $\mathrm{H}_{2} \mathrm{~S}$ renders its quantification in biological samples an experimental challenge. A compilation of methods currently employed to quantify $\mathrm{H}_{2} \mathrm{~S}$ in biological specimens is provided in this review. Substantial discrepancy exists in the concentrations of $\mathrm{H}_{2} \mathrm{~S}$ determined by different techniques. Available methodologies permit end-point measurement of $\mathrm{H}_{2} \mathrm{~S}$ concentration, yet no definitive protocol exists for the continuous, real-time measurement of $\mathrm{H}_{2} \mathrm{~S}$ produced by its enzymatic sources. We present a summary of available animal models, monogenic diseases that impair $\mathrm{H}_{2} \mathrm{~S}$ metabolism in humans including structure-function relationships of pathogenic mutations, and discuss possible approaches to overcome current limitations of study.

Keywords: hydrogen sulfide; transsulfuration; sulfur metabolite; genetic disease; cystathionine beta-synthase; metabolism

\section{Introduction \\ 1.1. Biological Chemistry of $\mathrm{H}_{2} \mathrm{~S}$}

Hydrogen sulfide $\left(\mathrm{H}_{2} \mathrm{~S}\right)$ is the smallest biological thiol. In the biosphere, $\mathrm{H}_{2} \mathrm{~S}$ is both an environmental toxin and a signaling metabolite with increasingly investigated roles in human physiology. An excellent review about the timeline of $\mathrm{H}_{2} \mathrm{~S}$ investigation from its discovery by Swedish-German chemist Carl Wilhelm Scheele until present is available from Csaba Szabo [1]. This review focuses on the biosynthesis and quantification of $\mathrm{H}_{2} \mathrm{~S}$ and on possible disturbances caused by genetic defects of metabolism that impair its turnover in humans. Thiols are nucleophiles of generally good reducing capacity that can engage in one- and two-electron transfer reactions [2]. Reaction mechanisms involving the transfer of one electron produce the corresponding reactive thiyl radical species. Twoelectron oxidation of thiols yields disulfide species. The reactivity of $\mathrm{H}_{2} \mathrm{~S}$ is comparable to that of other low molecular weight thiols, including its undergoing reversible as well as irreversible modifications. Reactions of $\mathrm{H}_{2} \mathrm{~S}$ with other reactive species, including oxygenand nitrogen-centered radicals have been comprehensively reviewed elsewhere [3-5]. 
Hydrogen sulfide is a weak acid with $\mathrm{pK}_{\mathrm{a}} \sim 7.0$ (Figure 1). Recent Raman studies of sodium sulfide dissolved in hyper-concentrated $\mathrm{NaOH}(\mathrm{aq})$ and $\mathrm{CsOH}(\mathrm{aq})$ cast serious doubt on the widely assumed existence of $\mathrm{S}^{2-}$ (aq) [6]. Under physiological $\mathrm{pH}, \mathrm{H}_{2} \mathrm{~S}$ exists predominantly as a hydrosulfide anion $\left(\mathrm{HS}^{-}\right)$. It has been estimated that approximately

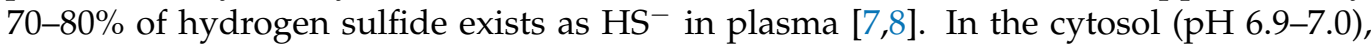
approximately $50 \%$ of hydrogen sulfide exists as $\mathrm{HS}^{-}$. In specific organelles, the proportion of the different ionized forms of hydrogen sulfide may vary. For example, in lysosomes ( $\mathrm{pH}$ 4.7-5.0), $\mathrm{H}_{2} \mathrm{~S}$ would be the predominant species, whereas in the more alkaline microenvironment of the mitochondrial matrix $(\mathrm{pH}>7.8), \mathrm{HS}^{-}$has been estimated to represent $92 \%$ of all available sulfide.

$$
H_{2} S_{(g)} \rightleftharpoons H_{2} S_{(a q)} \stackrel{p K_{a}}{\rightleftharpoons} H S^{-}+H^{+}
$$

Figure 1. Ionization properties of $\mathrm{H}_{2} \mathrm{~S}$. Hydrogen sulfide exists as an equilibrium of its gaseous and aqueous forms. Deprotonation of $\mathrm{H}_{2} \mathrm{~S}$ to form $\mathrm{HS}^{-}$has a $\mathrm{pK}_{\mathrm{a}}$ of 6.9-7.1.

In this review, the term $\mathrm{H}_{2} \mathrm{~S}$ refers to the sum of $\mathrm{H}_{2} \mathrm{~S} / \mathrm{HS}^{-}$. The signaling properties of $\mathrm{H}_{2} \mathrm{~S}$ have often been compared to those of the gasotransmitters nitric oxide (NO) and carbon monoxide (CO) [9]. Among the similarities, all three signaling molecules are gases, are synthesized by enzymes and possess in vivo half-lives of seconds to minutes. The major difference that prevails until present time is the absence of a conserved canonical receptor molecule for $\mathrm{H}_{2} \mathrm{~S}$, which is in contrast to the case of $\mathrm{NO}$ and $\mathrm{CO}$, both of which exert their functions via the $\mathrm{sGC} / \mathrm{cGMP}$ signaling axis [9]. An excellent review on $\mathrm{H}_{2} \mathrm{~S}$ signaling in the context of other known gasotransmitters is available elsewhere [10-12].

\subsection{Concentration, Signaling and Cellular Response to $\mathrm{H}_{2} \mathrm{~S}$}

As a redox signaling metabolite, the effects of $\mathrm{H}_{2} \mathrm{~S}$ in physiology are determined by three major factors, namely, concentration, compartmentalization and reactivity [13]. Firstly, the concentrations of $\mathrm{H}_{2} \mathrm{~S}$ in cells and extracellular compartments are maintained in a narrow physiological range by modulation of its biogenesis (transsulfuration pathway and microbiome production) and catabolism (mitochondrial oxidation) (Table 1). The occurrence of mutations in genes encoding enzymes responsible for the biosynthesis and catabolism of $\mathrm{H}_{2} \mathrm{~S}$ can increase and reduce the concentration of $\mathrm{H}_{2} \mathrm{~S}$ outside optimal homeostatic concentration. The exact contribution of the microbiome to overall $\mathrm{H}_{2} \mathrm{~S}$ concentration is a matter of active investigation [14-16]. It is noteworthy that the reported concentrations of $\mathrm{H}_{2} \mathrm{~S}$ in biological compartments vary substantially across laboratories. It has been noted that the reported concentrations of $\mathrm{H}_{2} \mathrm{~S}$ have decreased over time [2], likely due to the optimization of methods for its quantification (see also Table 1). However, these technical barriers are far from overcome. Publications reporting plasma concentrations of $\mathrm{H}_{2} \mathrm{~S}$ in the middle to high micromolar range continue to emerge [17-20], which complicates data interpretation and comparisons between different laboratories. Plasma concentrations of $\mathrm{H}_{2} \mathrm{~S}>10 \mu \mathrm{M}$ are an overestimation that hampers meaningful interpretation of $\mathrm{H}_{2} \mathrm{~S}$ effects in physiology. The same applies for cerebrospinal fluid, for which concentrations of ca $8.7 \mu \mathrm{M}$ and $102 \mu \mathrm{M}$ have been reported in pediatric and adult human subjects, respectively [21,22]. Excellent reviews on what may constitute physiological concentrations of $\mathrm{H}_{2} \mathrm{~S}$ are available $[23,24]$. Details on existing methods of quantification of $\mathrm{H}_{2} \mathrm{~S}$ have been covered in prior reviews [12,23,25-27] and updates are provided in the following sections of this review. Secondly, the physiological actions of $\mathrm{H}_{2} \mathrm{~S}$ are dictated by its diffusion capacity away from the respective sites of biosynthesis, or in other words, its compartmentalization. The solubility and diffusion of $\mathrm{H}_{2} \mathrm{~S}$ across biological membranes has been studied and reviewed comprehensively (Figure 2) [28,29]. One study utilized a 3D spherical diffusion model representing "a mammalian cell" that produces $\mathrm{H}_{2} \mathrm{~S}$ in a continuous manner from its surface. By applying a condition that involves free diffusion of $\mathrm{H}_{2} \mathrm{~S}$ in aqueous medium, without membranes, the authors determined that $\mathrm{H}_{2} \mathrm{~S}$ would reach 
260-590 neighboring cells. Introduction of resistance by lipid membranes at $\mathrm{pH} 7.4$ was shown to predict a slowdown of diffusion in tissues (based on this 3D model of the cell), leading to local accumulation of $\mathrm{H}_{2} \mathrm{~S}$ near the source [28]. The authors estimated that the ionization states of $\mathrm{H}_{2} \mathrm{~S}$ modify the apparent diffusion coefficient from $1.51 \times 10^{-5} \mathrm{~cm}^{2} / \mathrm{s}$ at $\mathrm{pH} 7.4$ to $1.94 \times 10^{-5} \mathrm{~cm}^{2} / \mathrm{s}$ at $\mathrm{pH}$ 6.5. Considering the existence of membranes and $\mathrm{pH} 7.4, \mathrm{H}_{2} \mathrm{~S}$ has a predicted diffusional capacity that extends up to 200 cells away from a single producing cell over a biosynthesis time span of $1 \mathrm{~s}$ (with a membrane permeability coefficient of $3 \mathrm{~cm} / \mathrm{s}$ ). This property supports the classification of $\mathrm{H}_{2} \mathrm{~S}$ as a paracrine signaling molecule [28]. An independent mathematical model of $\mathrm{H}_{2} \mathrm{~S}$ metabolism suggested that $\mathrm{H}_{2} \mathrm{~S}$ is consumed mainly by mitochondrial oxidation and by diffusion out of the cell, with the former process being the primary regulator of $\mathrm{H}_{2} \mathrm{~S}$ concentration [30]. Within the constraints of necessary mathematical assumptions (such as "working" concentrations of $\mathrm{H}_{2} \mathrm{~S}$, single exponential kinetic course, $\mathrm{pH}$ changes, approximate $\mathrm{H}_{2} \mathrm{~S}$ diffusion distances), it was postulated that very little $\mathrm{H}_{2} \mathrm{~S}$ diffuses out of cells, which would be mirrored by little if any $\mathrm{H}_{2} \mathrm{~S}$ in blood [30]. In vitro studies indicated that both $\mathrm{H}_{2} \mathrm{~S}$ (simple diffusion) and HS $^{-}$(facilitated diffusion by anion exchange protein AE1 in erythrocytes) produced by tissues enter red blood cells rapidly, thereby acting as a sink for $\mathrm{H}_{2} \mathrm{~S}$ and lowering extracellular concentration of the gasotransmitter [31]. As can be appreciated from these in-depth experimental studies and predictions, the properties and relationships of the sources and sinks of $\mathrm{H}_{2} \mathrm{~S}$ are complex. The extent and effects of $\mathrm{H}_{2} \mathrm{~S}$ mobilization in the biological milieu require further investigation.

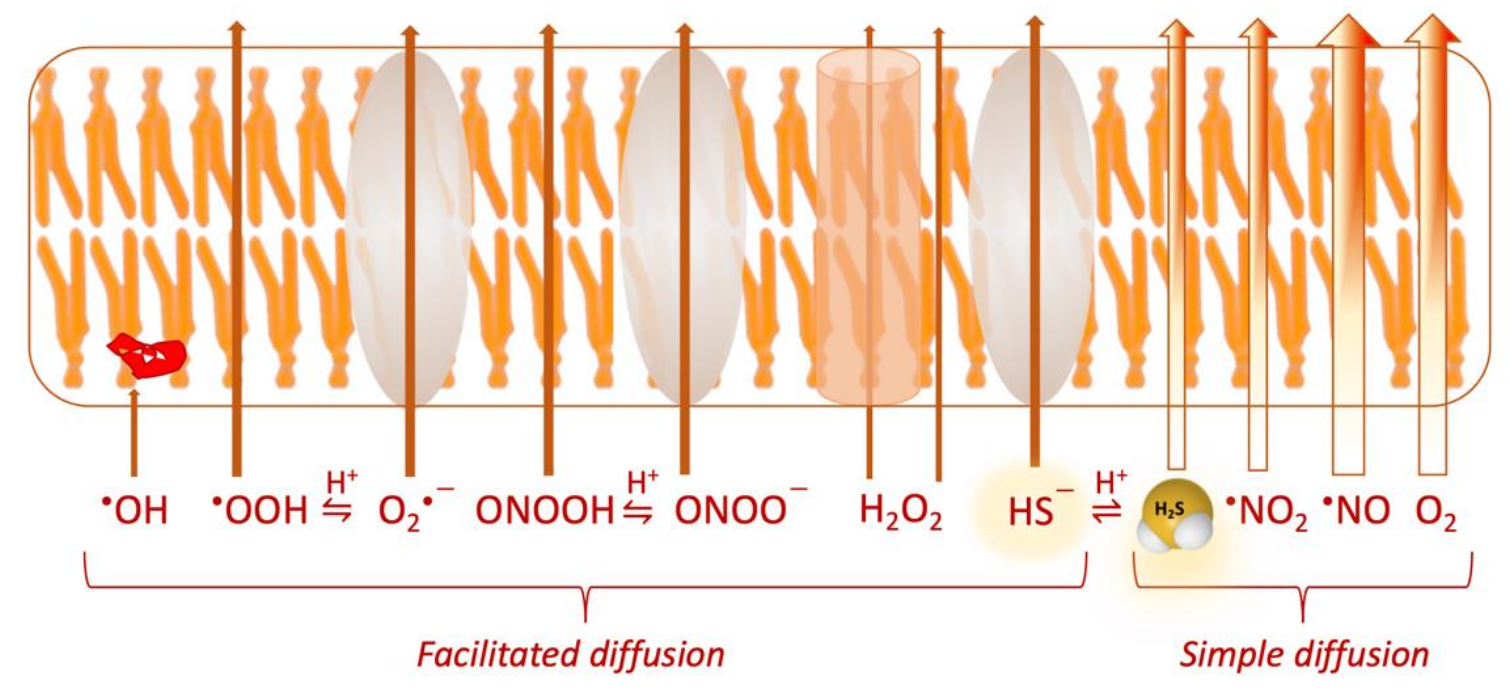

Cell membrane

Anion exchange protein channels

Aquaporin

Figure 2. Permeability of $\mathrm{H}_{2} \mathrm{~S}$ across biological membranes. The permeability of membranes to the different reactive species is proportional to their corresponding arrow size. Based on the studies and classification published by Möller et al. [29], $\mathrm{H}_{2} \mathrm{~S}$ mobilizes across lipid membranes primarily by simple diffusion. Studies on erythrocyte membranes showed that mobilization of $\mathrm{HS}^{-}$occurs by facilitated diffusion via anion exchange protein AE1 [31]. In contrast, oxidants such as $\mathrm{ONOO}^{-}$and $\mathrm{O}_{2}{ }^{\bullet-}$ require anion channels to traverse biological membranes. Mobilization of $\mathrm{H}_{2} \mathrm{O}_{2}$ across membranes is tightly controlled by cells. The reactivity of hydroxyl radical $(\bullet \mathrm{OH})$ outcompetes diffusion, which results in marked targeting of components of the membrane surface. Figure modified from Möller et al. [29]. 
Table 1. Concentration of $\mathrm{H}_{2} \mathrm{~S}$ in biological compartments.

\begin{tabular}{|c|c|c|c|}
\hline Specimen Type & {$\left[\mathrm{H}_{2} \mathrm{~S}\right]$} & Methods of Detection & Reference \\
\hline \multicolumn{4}{|l|}{ (1) Animal } \\
\hline Mouse brain & $14 \mathrm{nM}$ & Gas chromatography/chemiluminescence sulfur detector & [32] \\
\hline Mouse liver & $17 \mathrm{nM}$ & Gas chromatography/chemiluminescence sulfur detector & [32] \\
\hline Mouse plasma & $0.7 \mu \mathrm{M}$ & Monobromobimane assay & [33] \\
\hline Mouse whole blood & $15 \mathrm{nM}$ & GC method and chemiluminescence detection & [34] \\
\hline Rat whole blood & $0.7 \mu \mathrm{M}$ & Monobromobimane assay & [35] \\
\hline Rat aorta & $10 \mathrm{nM}$ & Polarographic electrode PHSS & [36] \\
\hline Rat liver and heart & $>100 \mathrm{nM} / \mathrm{g}$ & Photometric detector and ion chromatography & [37] \\
\hline Rat brain & $9 \mu \mathrm{M}$ & Gas chromatography/silver particles & [38] \\
\hline Rat homogenate tissue & $6 \mathrm{pM}$ & Gas chromatography/silver particles & [38] \\
\hline \multicolumn{4}{|l|}{ (2) Human } \\
\hline Human breath & $0.2 \mathrm{ng} / \mathrm{L}(0.1 \mathrm{ppb})$ & Chromatography & [39] \\
\hline Human saliva & $1.641-7.124 \mu \mathrm{M}$ & Fluorescent probe & {$[40]$} \\
\hline Human brain tissue & $100 \mu \mathrm{M}$ & Gas dialysis/ion chromatography & [41] \\
\hline Human cerebrospinal fluid & $\begin{array}{l}3.48 \pm 1.68 \mathrm{mg} / \mathrm{L} \\
(102 \pm 49 \mu \mathrm{M})\end{array}$ & $\begin{array}{l}\text { Selective electrochemical detection with ion } \\
\text { chromatography }\end{array}$ & [22] \\
\hline $\begin{array}{l}\text { Human cerebrospinal fluid } \\
\text { (pediatric patients) }\end{array}$ & $8.71 \pm 1.25 \mu \mathrm{M}$ & Electrode (PXS-270, Shanghai Leici, China) & [21] \\
\hline Human whole blood & $100 \mathrm{pM}$ & Gas chromatography/chemiluminescence sulfur detector & [32] \\
\hline $\begin{array}{l}\text { Human plasma } \\
\text { (pediatric patients) }\end{array}$ & $45.55 \pm 6.55 \mu \mathrm{M}$ & Electrode (PXS-270, Shanghai Leici, China) & [21] \\
\hline \multirow{6}{*}{ Human plasma } & $300-500 \mathrm{nM}$ & Monobromobimane (MMB) assay & [25] \\
\hline & $400-1000 \mathrm{nM}$ & Monobromobimane assay & {$[42]$} \\
\hline & $70-125 \mu \mathrm{M}$ & Microfluidic device with 2,6-dansyl azide (DNS-Az) probe & [20] \\
\hline & c.a $5-100 \mu \mathrm{M}$ & Methylene blue/UV-visible spectrophotometry & [17] \\
\hline & $54.0 \pm 26.4 \mu \mathrm{M}$ & Methylene blue/UV-visible spectrophotometry & {$[18]$} \\
\hline & $14.11 \pm 5.24 \mu \mathrm{M}$ & Methylene blue/UV-visible spectrophotometry & [19] \\
\hline
\end{tabular}

The physiological effects of varying $\mathrm{H}_{2} \mathrm{~S}$ concentrations appear to be specific for cell type and the dose (Table 2). Elevation of $\mathrm{H}_{2} \mathrm{~S}$ appears to be associated with proinflammatory effects $[14,43,44]$, whereas low to normal concentrations of $\mathrm{H}_{2} \mathrm{~S}$ exert antiinflammatory effects $[45,46]$. Likewise, the pharmacological actions of $\mathrm{H}_{2} \mathrm{~S}$ follow a bellshaped curve (reviewed in [47]). Both the inhibition of endogenous $\mathrm{H}_{2} \mathrm{~S}$ biosynthesis (that has stimulatory effects on ATP production, being cytoprotective) as well as supplementation with exogenous pharmacological donors of $\mathrm{H}_{2} \mathrm{~S}$ (that enhances cytostatic and cytotoxic actions) afford anti-cancer effects [47]. 
Table 2. Reported effects of $\mathrm{H}_{2} \mathrm{~S}$ in selected cell types.

\begin{tabular}{|c|c|c|c|c|}
\hline Cell Type & $\mathrm{H}_{2} \mathrm{~S}$ Dosage & Mechanism & Response & Reference \\
\hline \multirow{3}{*}{ Neurons, glia } & Supraphysiological & $\begin{array}{l}\text { Stimulation of NMDA receptors, } \\
\text { induced by an increase of cAMP } \\
\text { concentration }\end{array}$ & $\begin{array}{l}\text { Causes/contributes } \\
\text { to tissue damage, } \\
\text { neuroinflammatory }\end{array}$ & [43] \\
\hline & Physiological & & $\begin{array}{l}\text { Messenger in response to specific } \\
\text { stimuli (usually noxious) }\end{array}$ & [43] \\
\hline & Physiological & $\begin{array}{l}\text { Increasing the concentration of } \\
\text { glutathione, activating } \mathrm{K}^{+} \mathrm{ATP} \text { and } \\
\qquad \mathrm{Cl}^{-} \text {channels }\end{array}$ & Protection from oxidative stress & {$[46,48]$} \\
\hline \multirow{3}{*}{$\begin{array}{l}\text { Vascular } \\
\text { endothelial } \\
\text { cells }\end{array}$} & Release of $\mathrm{H}_{2} \mathrm{~S}$ & $\begin{array}{c}\text { Membrane hyperpolarization } \\
\text { (opening of the VSMC } \mathrm{K}^{+} \mathrm{ATP} \\
\text { channels), reduction of } \\
\text { extracellular } \mathrm{Ca}^{2+} \text { entry }\end{array}$ & Vasorelaxant effect & [49] \\
\hline & Exogenous $\mathrm{H}_{2} \mathrm{~S}$ & $\begin{array}{c}\text { Suppression of VSMC } \\
\text { proliferation through protein } \\
\text { kinase (MAPK) signaling pathway }\end{array}$ & $\begin{array}{l}\text { Attenuation of cell proliferation rate, } \\
\text { increase of cell apoptosis, regulation } \\
\text { of cell growth, structural remodeling } \\
\text { of vessel tissues }\end{array}$ & {$[49,50]$} \\
\hline & $\begin{array}{l}\text { Reduced (e.g., due to } \\
\text { CSE deficiency) }\end{array}$ & Loss of regulatory effects & $\begin{array}{l}\text { Hypertension, atherosclerosis, } \\
\text { myocardial injury }\end{array}$ & {$[51]$} \\
\hline \multirow[t]{2}{*}{$\begin{array}{l}\text { Pulmonary } \\
\text { artery cells }\end{array}$} & Endogenous release & $\begin{array}{l}\text { Inhibition of proliferation and } \\
\text { interleukin- (IL)- } 8 \text { secretion by } \\
\text { impairing extracellular } \\
\text { signal-regulated kinase } 1 / 2 \\
\text { (ERK1/2) and p38-dependent } \\
\text { signaling pathways }\end{array}$ & $\begin{array}{l}\text { Lung remodeling, inhibiting } \\
\text { collagen accumulation in the wall of } \\
\text { the pulmonary artery in hypoxia }\end{array}$ & [52] \\
\hline & $\begin{array}{l}\text { Inhibition of } \\
\text { endogenous } \mathrm{H}_{2} \mathrm{~S} \\
\text { release }\end{array}$ & $\begin{array}{l}\text { Signal-regulated kinase } 1 / 2 \\
(\text { ERK1/2) and p38-dependent } \\
\text { signaling pathways active }\end{array}$ & $\begin{array}{l}\text { Increased human airway, smooth } \\
\text { muscle proliferation, IL-8 secretion }\end{array}$ & [53] \\
\hline $\begin{array}{l}\text { Pancreatic } \\
\text { islets cells }\end{array}$ & Physiological & $\begin{array}{c}\text { Stimulation of } \mathrm{K}^{+} \text {ATP channels in } \\
\beta \text {-cells, possible inhibition of } \\
\text { insulin release by activation of } \\
\mathrm{K}^{+} \text {ATP channels }\end{array}$ & $\begin{array}{l}\text { Inhibition of insulin release, } \\
\text { induction of apoptosis }\end{array}$ & {$[54,55]$} \\
\hline \multirow{3}{*}{ Colonocytes } & Release of $\mathrm{H}_{2} \mathrm{~S}$ & $\begin{array}{l}\text { Activation of } \mathrm{K}^{+} \mathrm{ATP} \text { channels in } \\
\text { the vascular tissue, stimulation of } \\
\text { vanilloid type I receptor }\end{array}$ & $\begin{array}{l}\text { Inhibition of jejunum and colon } \\
\text { motility, regulation of the gastric } \\
\text { mucosal blood flow, secretion and } \\
\text { increased spike activity in the } \\
\text { afferent neurons of the enteric } \\
\text { nervous system }\end{array}$ & {$[56,57]$} \\
\hline & Supraphysiological & $\begin{array}{l}\text { Inhibits cytochrome c oxidase and } \\
\text { synthesis of ATP }\end{array}$ & $\begin{array}{l}\text { Pro-inflammatory, suppresses } \\
\text { mitochondrial energy production, } \\
\text { destabilizes the protective intestinal } \\
\text { mucus layer, potentially participates } \\
\text { in the etiology of bowel disorders, } \\
\text { occurs as genotoxic agent in } \\
\text { colorectal cancer }\end{array}$ & {$[14,44,58]$} \\
\hline & Low concentration & Energy substrate & Anti-inflammatory & [45] \\
\hline
\end{tabular}

Thirdly, $\mathrm{H}_{2} \mathrm{~S}$ and a series of reactive sulfur species (RSS), including polysulfides, persulfides and thiosulfates, can modify target proteins and induce specific physiological effects $[59,60]$. The persulfidation reaction appears to be the major pathway for sulfurmediated post-translational modification of proteins [11]. For example, persulfidation stabilizes superoxide dismutase (SOD) against oxidation-induced aggregation without affecting its catalytic activity [61]. Persulfide modifications on proteins are reversible and, unless sequestered, labile. Interchange reactions with glutathione (GSH), thioredoxin (Trx) 
or cysteine can undo persulfidation [11]. In mammals, sulfurtransferases involved in sulfide synthesis and oxidation produce active site persulfides. On the other hand, polysulfides, which are more reactive than $\mathrm{H}_{2} \mathrm{~S}$, activate transient receptor potential (TRP) A1 channels, inhibit lipid phosphatase PTEN52 and activate transcription factor Nrf2 by modification of Keap1 [62]. The specificity of this mechanism demands further investigation. In bacteria, polysulfides and elemental sulfane sulfur can be produced during sulfide oxidation by sulfide quinone oxidoreductase (SQOR) [63]. In contrast, mammalian SQRs form persulfide rather than polysulfide [64-66]. The modification of the target protein takes place either directly or indirectly via a secondary carrier.

Besides RSS with S-S bonds, hydrogen sulfide can form other reactive species that contain sulfur-oxygen bonds [67-69]. Key intermediates in the oxidation of sulfide to sulfate are the so-called small oxoacids of sulfur (SOS)—sulfenic $\mathrm{HSOH}$ and sulfoxylic $\mathrm{S}(\mathrm{OH})_{2}$ acids. These $\mathrm{SOS}$ appear relatively long lived in aqueous solution, and thus may be involved in the observed physiological effects of $\mathrm{H}_{2} \mathrm{~S}$.

\section{Biogenesis, Catabolism and Reservoir of Hydrogen Sulfide in Humans}

\subsection{Enzymatic Production of Hydrogen Sulfide}

Biogenesis of hydrogen sulfide in humans occurs via two major routes: by endogenous specialized enzymes and as an end-product or intermediate of microbial metabolic pathways within the gut microbiota [10].

Endogenous production of hydrogen sulfide in mammals is carried out by three enzymes: cystathionine $\beta$-synthase (CBS), cystathionine $\gamma$-lyase (CSE, also known as cystathionase) and 3-mercaptopyruvate sulfurtransferase (MST) [10,70]. Enzymes CBS and CSE are localized in the cytosol whereas MST resides in the mitochondrion (Figure 3).

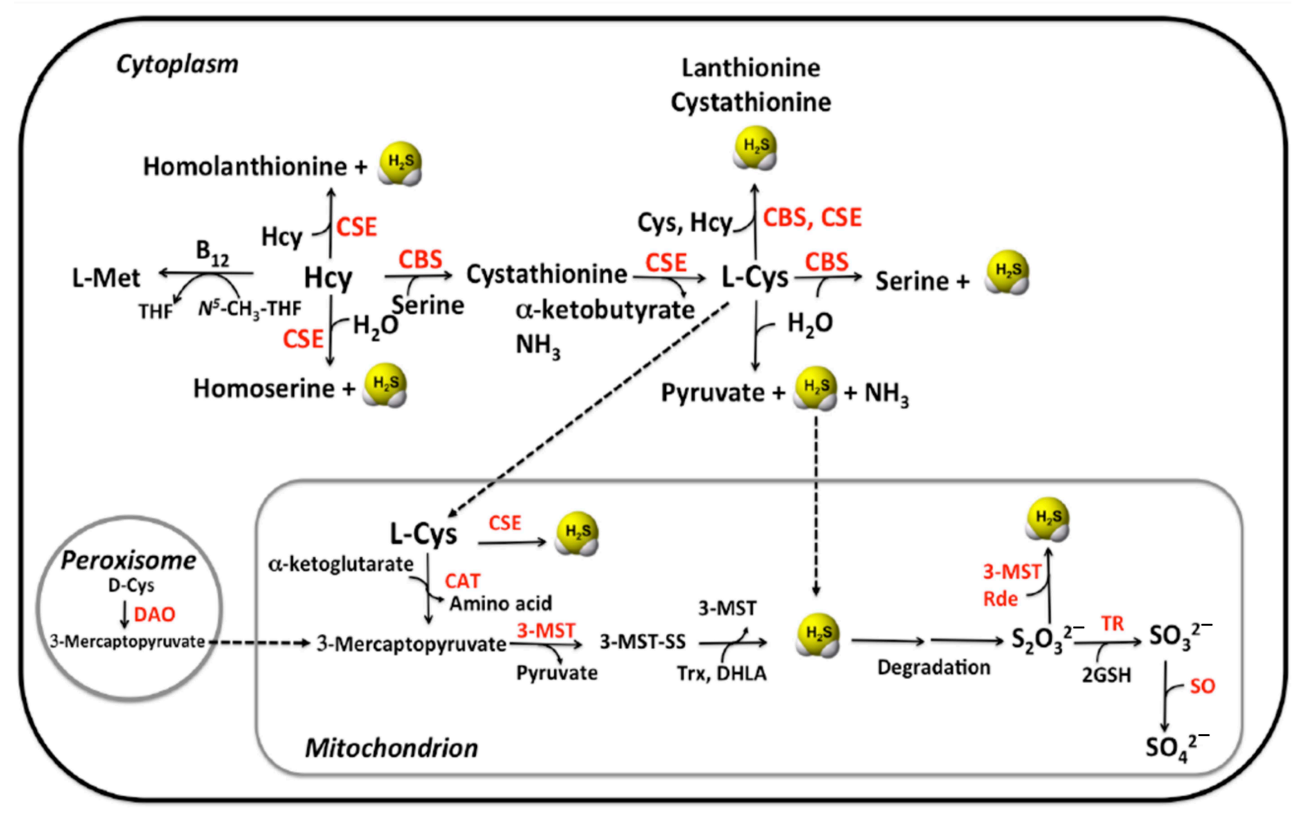

Figure 3. Biogenesis of $\mathrm{H}_{2} \mathrm{~S}$. Overview of reactions and compartments for the biosynthesis of $\mathrm{H}_{2} \mathrm{~S}$. CBS: Cystathionine $\beta$-synthase; CSE: Cystathionine $\gamma$-lyase; DAO: D-amino acid oxidase; 3MST: 3-mercaptopyruvate sulfurtransferase; CAT: Cysteine aminotransferase; Rde: rhodanese; SO: sulfite oxidase; Trx: thioredoxin. Modified from Libiad et al. [65].

CBS and CSE are pyridoxal 5'-phosphate (PLP-) dependent enzymes of the transsulfuration pathway that convert homocysteine into cysteine. All available homocysteine in the cell derives from methionine catabolism [71].

CBS catalyzes the $\beta$-replacement of serine (Ser) by homocysteine to form cystathionine. Downstream, CSE catalyzes the conversion of cystathionine to cysteine, $\alpha$-ketobutyrate and 
ammonia in a $\alpha, \gamma$-elimination reaction. In addition, CBS and CSE participate in various side reactions, which generate the signaling molecule hydrogen sulfide $\left(\mathrm{H}_{2} \mathrm{~S}\right)$ as a side product (Figure 4) [72]. Formation of cystathionine from L-Cys and L-Hcy yields $\mathrm{H}_{2} \mathrm{~S}$ both in the reactions catalyzed by CBS and CSE. In addition, CSE catalyzes the formation of the products lanthionine and homolanthionine from substrate combinations Cys/Cys and Hcy/Hcy, respectively, both of which produce $\mathrm{H}_{2} \mathrm{~S}$. Thioether metabolites lanthionine and homolanthionine have been proposed as biomarkers of hydrogen sulfide generation in patients with CBS deficiency [73].

The third PLP-dependent pathway involves the enzyme aspartate aminotransferase (AAT), which has cysteine aminotransferase (CAT) activity [74]. In combination with the PLP-independent enzyme 3-mercaptopyruvate sulfurtransferase (MST), sulfane sulfur can be generated, which, after reduction, can liberate hydrogen sulfide.

\subsubsection{CBS}

Cystathionine $\beta$-Synthase (CBS) is the first enzyme of the transsulfuration pathway in which Hcy is converted to Cys [75]. A deficiency of this enzyme due to an inherited mutation leads to accumulation of Hcy to toxic concentrations. Deficiency of CBS is the most common cause of homocystinuria, an inherited metabolic disease with an impact on almost all human organs [75].

$C B S$ is mainly expressed in the brain, liver, kidney and pancreas (Figure 5). It is predominantly localized in the cytosol, but in specific cell lines CBS could be also found in the nucleus [76] and the mitochondrion [77]. This enzyme produces from 25 to $70 \%$ of the total concentration of endogenous $\mathrm{H}_{2} \mathrm{~S}$ [78].

The human CBS gene is located on chromosome 21 (i.e., 21q22.3) and it encodes a protein of 551 amino acids. The active form consists of four 63-kDa subunits [79,80]. Each subunit contains three structural domains, namely, N-terminal domain harboring heme, the catalytic domain containing PLP and the C-terminal domain with regulatory functions. The N-terminal domain binds to the heme-cofactor and enables successful protein folding and assembly, but it is not necessary for the catalytic activity of the enzyme [81]. The heme in CBS occurs in two oxidation states: ferric $\left(\mathrm{Fe}^{3+}\right)$ and ferrous $\left(\mathrm{Fe}^{2+}\right)$. Ferrous CBS can bind the gas signaling molecules, $\mathrm{CO}$ and $\mathrm{NO}$, which results in inhibition of its catalytic activity [82]. A recovery of the ferric heme state and its enzymatic activity is possible by air oxidation of the ferrous-CO or ferrous-NO forms of CBS. The catalytic domain of the enzyme has a binding site for another cofactor, PLP [75,79]. The C-terminal domain is the regulatory part and it consists of two CBS motifs (CBS1 and CBS2) that dimerize to form a Bateman domain. It is responsible for CBS subunit tetramerization and it contains the binding sites for the allosteric activator S-adenosylmethionine (SAM) $[79,83]$. SAM is a universal methyl group donor that supports over 200 methyltransferase reactions [84,85]. Allosteric modulator SAM stabilizes CBS [86] and can increase its enzymatic activity up to 5-fold [87]. In addition, SAM was shown to modulate binding of gasotransmitters $\mathrm{NO}$ and $\mathrm{CO}$ to the heme of CBS as another means to regulate enzymatic activity [88]. Another form of CBS regulation is post-translational modification by a small ubiquitinlike modifier (SUMO) protein, which is correlated with the localization of CBS in the nucleus [76,89]. Sumoylation of CBS depends on substrate concentration and leads to reduced catalytic activity [70]. All in all, the activity of CBS seems to be highly regulated. Still, $\mathrm{H}_{2} \mathrm{~S}$ production by $\mathrm{CBS}$ appears to be independent of blood Hcy concentrations, possibly related to the fact that the affinity of CBS for Hcy is lower than its affinity for serine or cysteine [10].

In terms of substrate specificity, CBS participates in the first and committing step of the transsulfuration pathway: the $\beta$-replacement of serine with homocysteine, yielding cystathionine and water [78]. Instead of serine, cysteine can also act as a substrate, which results in the formation of cystathionine and $\mathrm{H}_{2} \mathrm{~S}$ as reaction products. In addition, CBS catalyzes side reactions that produce $\mathrm{H}_{2} \mathrm{~S}$ from cysteine: the $\beta$-replacement of cysteine by water to form Ser and the $\beta$-replacement of Cys by a second mol of Cys to produce 
lanthionine. In both of these reactions, $\mathrm{H}_{2} \mathrm{~S}$ is eliminated and SAM enhances $\beta$-replacement by Hcy of Ser and Cys. Out of these reactions, the canonical $\beta$-replacement reaction of Cys with Hcy is kinetically most efficient toward the production of $\mathrm{H}_{2} \mathrm{~S}$ [78] (Figure 4).

CBS; $\beta$-Replacement

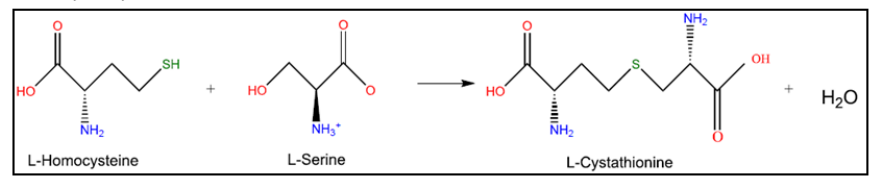

CSE, $\alpha, y$-Elimination

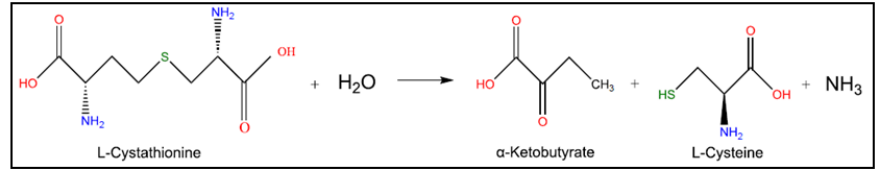

$C B S / C S E, \beta$-Elimination (CBS), $\alpha, \beta$-Elimination (CSE)

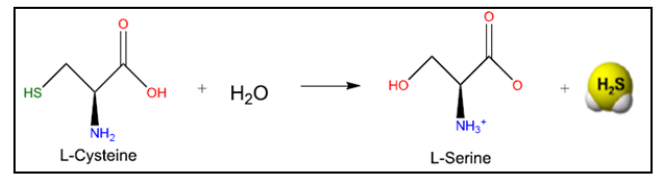

CBS/CSE, $\beta$-Replacement

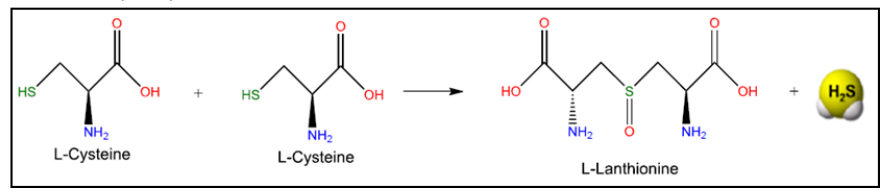

CSE, a,y-Elimination

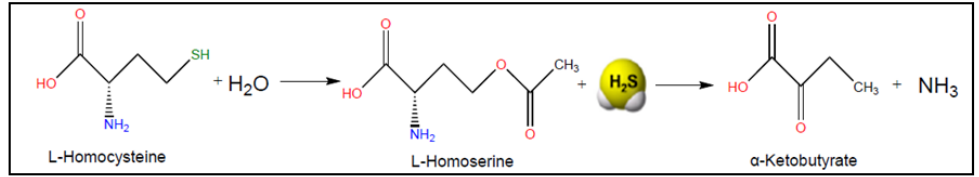

CSE, $\gamma$-Replacement

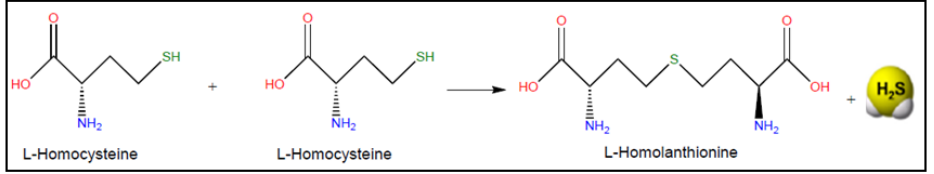

CBS/CSE, $\beta$-, $\gamma$-Replacement

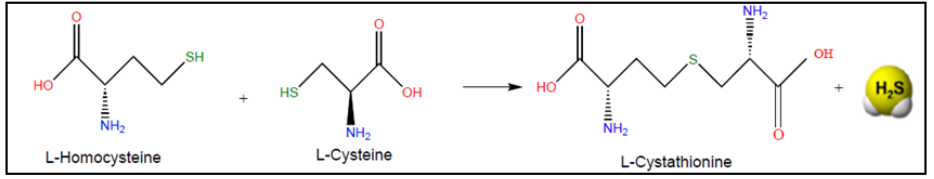

CBS/CSE, $\alpha, \beta$-Elimination

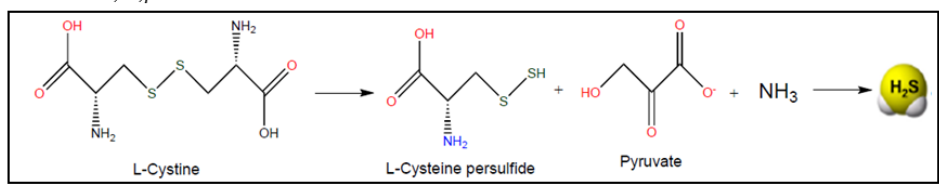

MST reaction

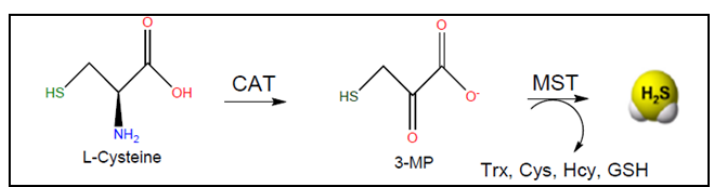

Figure 4. Canonical reactions of cystathionine- $\beta$-synthase (CBS), cystathionine- $\gamma$-lyase (CSE) and 3-mercaptopyruvate sulfurtransferase (MST). Modified from Giuffre and Vicente [10]. 


\subsubsection{CSE}

Cystathionine $\gamma$-lyase (CSE) is the second enzyme of the transsulfuration pathway, downstream from CBS. The main reaction of CSE is to cleave cystathionine to form cysteine, ammonia and $\alpha$-ketobutyrate. Like CBS, CSE catalyzes side reactions that lead to the formation of $\mathrm{H}_{2} \mathrm{~S}$, such as $\beta$-elimination of Cys, which is estimated to be the major reaction driving $\mathrm{H}_{2} \mathrm{~S}$ synthesis by CSE [3,78] (Figure 4).

CSE is mainly expressed in the liver, kidney, thoracic aorta, ileum, portal vein, uterus, brain, pancreatic islets and the placenta (Figure 5) [90-94]. Based on recent studies, CSE is the primary source of $\mathrm{H}_{2} \mathrm{~S}$ in the peripheral vasculature [95] and it shows modest presence and activity in the brain [94].

Human CSE is a tetramer with a subunit molecular mass of $45 \mathrm{kDa}$ [89]. Each subunit contains two CXXC motifs, whose influence on CSE activity via its predicted redox-sensing properties awaits experimental confirmation. Under in vitro conditions, CSE is posttranslationally modified by SUMO [89], a signal that is often used for nuclear localization. The physiological relevance and the possible impact, if any, of sumoylation on CSE function has not yet been described. Calmodulin increases the activity of CSE by 2-fold, even in the presence of high blood calcium concentration $(2 \mathrm{mM})[70,96]$. The regulation of CSE is still not very well understood.

CSE belongs to the $\gamma$-family of PLP-dependent enzymes and it catalyzes, as mentioned before, $\alpha, \gamma$-elimination of cystathionine to give Cys, $\alpha$-ketobutyrate and ammonia. A variety of CSE-catalyzed side reactions lead to $\mathrm{H}_{2} \mathrm{~S}$ formation, including cysteine-dependent $\beta$-reactions and homocysteine-dependent $\beta$-reactions [97]. An alternative route for $\mathrm{H}_{2} \mathrm{~S}$ synthesis from cysteine catalyzed by CSE has been proposed to involve $\beta$-elimination of cystine, which leads to the formation of thiocysteine as an intermediate product. Thiocysteine decomposes to $\mathrm{H}_{2} \mathrm{~S}$ thereafter, via non-enzymatic reaction with other thiols [97]. Furthermore, studies of Chiku et al. identified two novel sulfur metabolites generated as byproducts of $\mathrm{H}_{2} \mathrm{~S}$ synthesis by CSE: lanthionine and homolanthionine (Figure 4) [97].

Under normal conditions, approximately $70 \%$ of $\mathrm{H}_{2} \mathrm{~S}$ is produced from Cys and the remaining 30\% is from Hcy [97]. However, under conditions with higher concentrations of homocysteine, Hcy rather than Cys becomes the preferred main source for $\mathrm{H}_{2} \mathrm{~S}$ synthesis. According to Yang \& $\mathrm{He}, \mathrm{CBS}^{+/-}$mice showed upregulated CSE in the heart, suggesting that CBS deficiency induces CSE [98].

In addition, CSE has relaxed substrate specificity, which allows accommodation of cystathionine, cysteine and homocysteine in the same binding pocket where they compete for forming a Schiff base with PLP [78]. In contrast, the active site of CBS cannot accommodate two molecules of Hcy, but only one [78]. This has been proposed as the molecular basis by which $\mathrm{H}_{2} \mathrm{~S}$ production by CSE but not CBS is sensitive to homocysteine concentrations [78]. The concentration of $\mathrm{H}_{2} \mathrm{~S}$ generated by homocysteine-dependent reactions increases proportionally with the degree of hyperhomocysteinemia [97]. This implies that CSE may have a significant role in Hcy clearance at pathophysiological elevated Hcy concentration, particularly in tissues or organs with CBS deficiency [10]. Thus, under normal conditions (5-15 $\mu \mathrm{M}$ Hcy in plasma), CSE is responsible for $\sim 30 \%$ of the $\mathrm{H}_{2} \mathrm{~S}$ production in the transsulfuration pathway [78]. This amount can increase up to $\sim 45$ and $\sim 74 \%$ under moderate and severe hyperhomocysteinemic conditions [78].

In contrast to CBS, the activity of CSE is highly dependent on the cellular supply of PLP (vitamin B6) [72]. Therefore, $\mathrm{H}_{2} \mathrm{~S}$ production by CSE is limited under conditions of vitamin $\mathrm{B} 6$ shortage. In contrast, $\mathrm{CBS}$ is very resilient, maintaining much of its activity in all but severe states of vitamin B6 deficiency [72].

\subsubsection{MST}

3.-Mercaptopyruvate sulfur-transferase (3MST) is the third main $\mathrm{H}_{2} \mathrm{~S}$-generating enzyme, which participates in cysteine metabolism [99]). It acts in conjunction with cysteine aminotransferase (CAT), which is identical to aspartate aminotransferase (AAT), to produce $\mathrm{H}_{2} \mathrm{~S}$. 
MST produces $\mathrm{H}_{2} \mathrm{~S}$ from 3-mercaptopyruvate (3-MP), which is generated by CAT from Cys in the presence of $\alpha$-ketoglutarate [98,99] (Figure 4).

3. MST is expressed mainly in the liver, kidney, heart, lung, thymus, testis, thoracic aorta and the brain (Figure 5) $[100,101]$. Western blot analysis and enzymatic assays revealed the presence of active MST, but undetectable CBS and CSE, in red blood cells $[10,102]$ and the vascular endothelium [101]. In general, MST is described as a mitochondrial enzyme. Studies of Fräsdorf et al. described two cytosolic splice variants of the protein, MSTIso1 and MST-Iso2, with the latter also being identified in the mitochondria of HEK293a and HeLa cells $[10,103]$. Neuronal cells expressing 3MST and CAT exhibit resistance against oxidative glutamate toxicity [104]). The study suggested that $\mathrm{H}_{2} \mathrm{~S}$ produced by $3 \mathrm{MST} / \mathrm{CAT}$ clears reactive oxygen species in mitochondria and preserves the function of cells from oxidative damage.

In contrast to the enzymes of the transsulfuration pathway CBS and CSE, MST is inhibited under oxidative stress conditions [70]. MST has an active site cysteine residue, which is sensitive to oxidants.

Aspartate inhibits $\mathrm{H}_{2} \mathrm{~S}$ formation by 3MST/CAT [105]. This amino acid is a preferred substrate for CAT or AAT, thereby competing with 3 MST.

Recent work shows that thioredoxin could modulate MST activity as well [106]. Under physiologically relevant concentrations, reduced thioredoxin binds to MST and decreases its reaction rate constant for 3-MP compared to other sulfur acceptors. In contrast, under oxidizing conditions, oxidized thioredoxin increases the reaction rate and MST is free to interact with its substrate 3-MP. This could explain the observed stimulation of MST under oxidative stress conditions wherein the reduced form of thioredoxin is decreased [106].
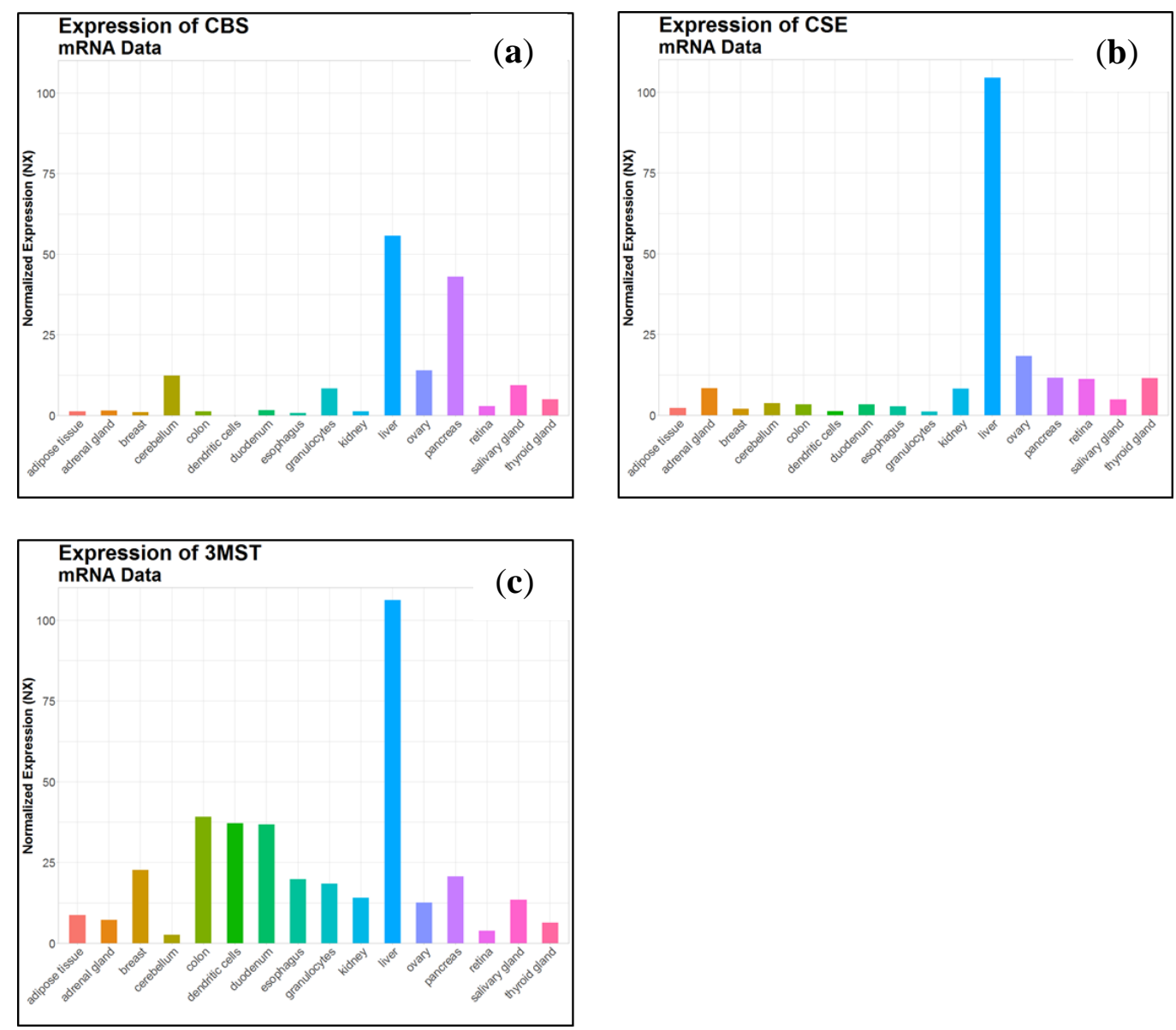

Figure 5. Normalized expression (NX) in different tissues of CBS (a), CSE (b), 3MST (c) ([107]; source data for the plots were downloaded from the Human Protein Atlas, v19.proteinatlas.org). 
The fraction of cysteine not employed for transsulfuration reactions, glutathione or protein biosynthesis, undergoes catabolism to yield cysteine sulfinic acid via oxidation of the thiol moiety by the enzyme cysteine dioxygenase [108]. Cysteine sulfinic acid is further processed via two distinct routes to produce taurine or sulfate as the final products, respectively. These pathways have been reviewed in detail elsewhere [108].

\subsection{Non-Canonical Biogenesis of $\mathrm{H}_{2} \mathrm{~S}$}

Besides the enzymes of sulfur amino acid metabolism, erythrocytes produce $\mathrm{H}_{2} \mathrm{~S}$ from inorganic and organic polysulfides $[109,110]$. It has been estimated that erythrocytes can produce $\mathrm{H}_{2} \mathrm{~S}$ at a constant concentration of $170 \mu \mathrm{mol}$ (L cells) ${ }^{-1} \mathrm{~min}^{-1}$ [110]. Experimental formation of $\mathrm{H}_{2} \mathrm{~S}$ was observed after addition of either GSH or nicotinamide adenine dinucleotide (NADH) or nicotinamide adenine dinucleotide phosphate (NADPH) to the cell lysate, which suggests a physiological role of $\mathrm{H}_{2} \mathrm{~S}$ as an electron carrier and an evolutionary link between the eukaryotic cytoplasm and sulfur-reducing Archaea [110]. In addition, human erythrocytes convert garlic-derived organic polysulfides into $\mathrm{H}_{2} \mathrm{~S}$ via glucosesupported and thiol- and glutathione-dependent reactions [109,111].

Studies by Akaike et al. demonstrated that mitochondrial enzyme cysteinyl tRNA synthetase (CARS2) plays a major role in catalyzing the conversion of Cys into Cys- per/ polysulfide species (Figure 6) [112]. Cys-per/polysulfides are efficiently reduced by the thioredoxin and GSH enzyme machineries using NADPH as a source of electrons [113]. Therefore, these non-canonical enzymatic pathways could contribute significant $\mathrm{H}_{2} \mathrm{~S}$ production in cells.

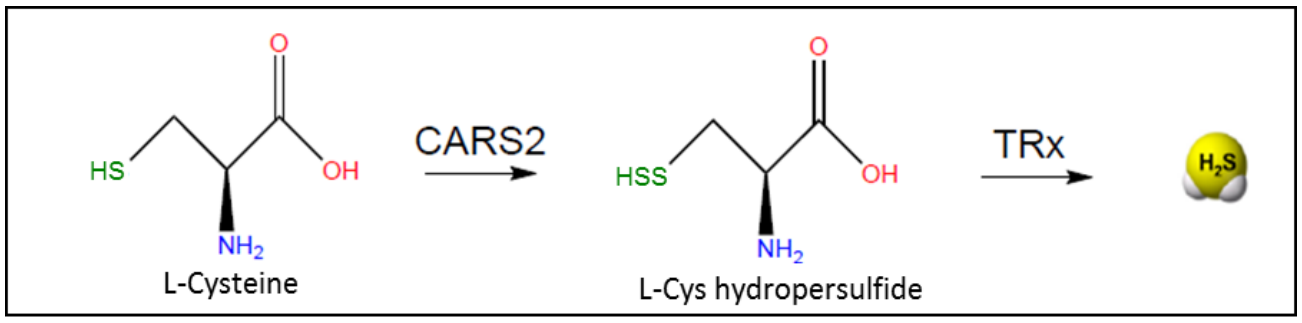

Figure 6. CARS2 reaction contributes to $\mathrm{H}_{2} \mathrm{~S}$ formation in cells (CARS2 = cysteinyl $t R N A$ synthetase, $\mathrm{TRx}=$ thioredoxin). Inspired by Akaike et al. [112].

Besides the systems described above, non-enzymatic formation of $\mathrm{H}_{2} \mathrm{~S}$ was also demonstrated in blood, with specificity toward precursor metabolite cysteine [114]. The study reported cysteine-dependent formation of $\mathrm{H}_{2} \mathrm{~S}$ via a reaction that requires pyridoxal phosphate and iron, including heme iron. The reaction progresses via formation of a cysteine-aldimine intermediate, and produces pyruvate, $\mathrm{NH}_{3}$ and $\mathrm{H}_{2} \mathrm{~S}$ as the final products [114]. Results from the study suggest that this reaction contributes very little to systemic, basal $\mathrm{H}_{2} \mathrm{~S}$ concentrations, but could prove detrimental in pathological conditions characterized by elevation of released iron such as is seen in hemolytic and hemorrhagic disorders [114]. In vitro studies indicate that met-hemoglobin scavenges and regulates sulfide pools in blood, including the maintenance of hemoglobin itself in its reduced, oxygen-binding form that is necessary for erythrocyte function [115]. The roles of sulfide pools in erythrocytes have been covered in detail elsewhere [116].

\subsection{Hydrogen Sulfide Derived from the Microbiome}

Besides enzymatic formation of $\mathrm{H}_{2} \mathrm{~S}$ by cells, the microbiome in the human gut plays an important role in the biogenesis of hydrogen sulfide [14].

The intestinal microbiome metabolizes cysteine and methionine in order to produce sulfur-containing structures, metabolites, signal molecules and cellular energetics [14]. Sulfate-reducing bacteria utilize thiosulfate to generate $\mathrm{H}_{2} \mathrm{~S}$. In the colonic lumen, several bacterial species are able to convert $C y s$ into $\mathrm{H}_{2} \mathrm{~S}$ [117]. In fact, numerous bacterial groups (Fusobacterium, Clostridium, Escherichia, Salmonella, Klebsiella, Streptococcus, Desulfovibrio, 
and Enterobacter) transform $\mathrm{Cys}$ to $\mathrm{H}_{2} \mathrm{~S}$, ammonia and pyruvate by the enzyme cysteine desulfhydrase $[16,118,119]$. In particular, Escherichia coli and Salmonella typhimurium were described to have a lack in enzymes that convert methionine to cysteine. Therefore, those species are not able to use methionine as a source for growth [120]. In contrast, Fusobacterium has at least four genes which encode for different enzymes catalyzing the production of $\mathrm{H}_{2} \mathrm{~S}$ [121]. One of the encoded enzymes is CSE which produces hydrogen sulfide and Ser from Cys. Another enzyme has been described as having "L-cysteine lyase" activity, perhaps similar to CSE. L-Cys lyase combines two cysteine residues to form lanthionine and $\mathrm{H}_{2} \mathrm{~S}$. Two distinct proteins with cysteine desulfhydrase activity have also been described [121].

Notably, a comparison of germ-free versus conventional mice showed that presence of the microbiota was associated with higher concentration of free $\mathrm{H}_{2} \mathrm{~S}$ not only in some intestinal tracts (colon and cecum) but also in plasma [122]. Moreover, the conventional mice showed higher concentrations of bound sulfane sulfur in plasma, fat and lung, a higher CSE activity, and in contrast, lower cysteine concentration in most organs and tissues [122]. Only the aorta tissue in germ-free mice had a significant clear decrease in cysteine concentration. The data of Shen et al. suggested that the presence of the microflora had an impact on CSE activity and Cys bioavailability [122]. One possible explanation could be that bacterial products leak into the bloodstream and induce $\mathrm{H}_{2} \mathrm{~S}$-generating enzymes. Another possibility is that a part of the $\mathrm{H}_{2} \mathrm{~S}$ bioequivalents found in blood and tissues of conventional mice is produced by sulfur-metabolizing bacteria in the gut lumen [122]. In addition, the characteristics and composition of the individual diet may have an impact on the concentration of luminal sulfide in the large intestine.

As mentioned earlier, $\mathrm{H}_{2} \mathrm{~S}$ has dual effects in colonocytes that depend on the specific concentration of the gasotransmitter (see also Table 2). Low concentrations of $\mathrm{H}_{2} \mathrm{~S}$ are antiinflammatory, whereas elevated concentrations of $\mathrm{H}_{2} \mathrm{~S}$ exert pro-inflammatory effects. A number of studies reported that physiological concentrations of microbial $\mathrm{H}_{2} \mathrm{~S}$ production are beneficial for the host $[16,122,123]$. Critical evaluation of available findings includes both pro- and anti-inflammatory actions of $\mathrm{H}_{2} \mathrm{~S}$ in the intestinal tract, as well as smooth muscle relaxation, pro-secretory and pro- and anti-nociceptive effects [124].

The regulation of $\mathrm{H}_{2} \mathrm{~S}$ concentration in the intestine depends on the balance between the activity of bacterial inorganic respiration, fermentative bacteria and sulfur amino acid metabolism by colonic cells themselves [16]. The co-evolution of the microbiota and the intestinal epithelial cells enables a sulfur metabolic system which maintains $\mathrm{H}_{2} \mathrm{~S}$ at a constant concentration relying on a predominantly anaerobic microbiota and an aerobic colonic cell [16]. Findings by Linden et al. support the proposal that high expression of $S Q O R$ in the colonic mucosa ensures rapid oxidation of $\mathrm{H}_{2} \mathrm{~S}$, which would substantially limit or preclude gasotransmitter transfer into the bloodstream [125]. The complexity of host-microbiome processing of $\mathrm{H}_{2} \mathrm{~S}$ has been reviewed in detail [124] and calls for further investigation.

\subsection{Catabolism of $\mathrm{H}_{2} \mathrm{~S}$}

Catabolism of hydrogen sulfide occurs primarily via the oxidation pathway in the mitochondrion with the concomitant production of ATP [126]. Oxidation of $\mathrm{H}_{2} \mathrm{~S}$ takes place in a variety of mammalian tissues including liver, kidney, heart and colonocytes. At the molecular level, two $\mathrm{H}_{2} \mathrm{~S}$ molecules diffuse into the mitochondria and bind to the active site of two sulfide quinone oxidoreductase (SQR) enzymes [66], each of them reducing two cysteine disulfide, forming a sulfane-sulfur group ( $S Q R-S S H)$. In the next step, the sulfane-sulfur group is transferred to either glutathione, dihydrolipoic acid or to Trx. Electrons derived from $\mathrm{H}_{2} \mathrm{~S}$ oxidation are transferred via ubiquinone to the respiratory chain, where they reduce coenzyme $Q$ via the cofactor FAD [126,127] and drive ATP synthesis [128]. Glutathione persulfide (GSSH) is further oxidized by persulfide dioxygenase (SDO) (encoded by the gene ETHE1) to sulfite, which is oxidized to sulfate by downstream sulfite oxidase $[108,129,130]$. Alternatively, sulfite can be metabolized by thiosulfate sulfurtransferase to thiosulfate [131]. The enzyme rhodanese has been recognized 
in the mitochondrial oxidation pathway. According to recent studies, rhodanese catalyzes the transfer of sulfane sulfur from GSSH to sulfite to form thiosulfate [64,65]. Rhodanese is localized in liver, kidney [132] and also in colon, where it seems important in the detoxification of $\mathrm{H}_{2} \mathrm{~S}$ produced by the gut microbiota $[133,134]$. In summary, $S Q R$ and sulfur dioxygenase are reported as possible key regulators of $\mathrm{H}_{2} \mathrm{~S}$ catabolism [66]. They might switch off sulfide signaling by consuming $\mathrm{H}_{2} \mathrm{~S}$ and its product (Figure 7).

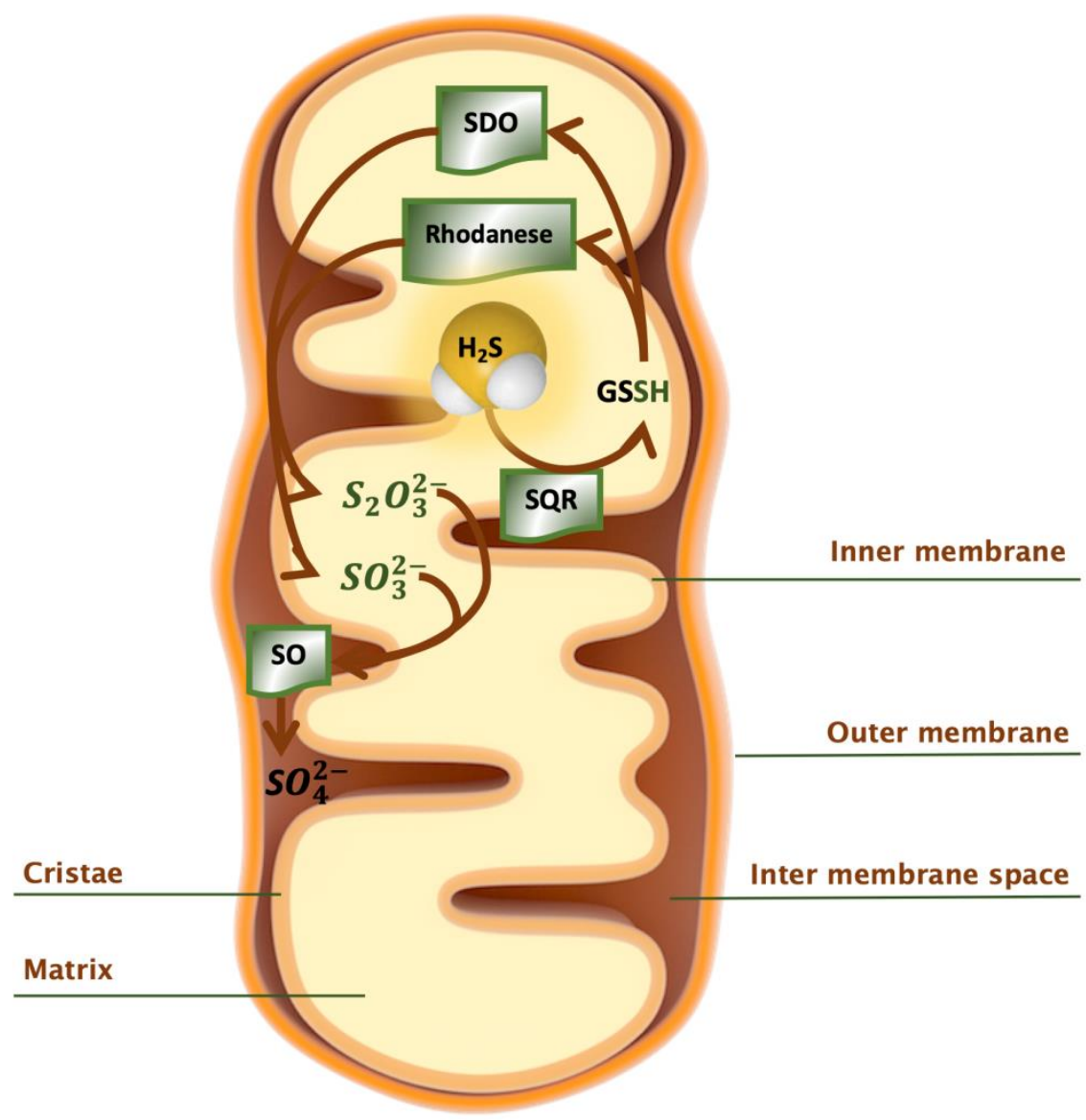

Figure 7. Oxidation pathway of $\mathrm{H}_{2} \mathrm{~S}$. In the mitochondrial matrix, SQR oxidizes $\mathrm{H}_{2} \mathrm{~S}$ to GSSG and transfers the derived electrons to the respiratory chain, where they reduce coenzyme $Q$ and drive ATP synthesis. GSSG undergoes further oxidation by SDO forming sulfite. Alternatively, rhodanese catalyzes GSSG, forming a thiosulfate anion. In the next step, the products sulfite and thiosulfate anions are oxidized to sulfate by the enzyme sulfite oxidase. (SQR = sulfide quinone oxidoreductase, $\mathrm{SDO}=$ persulfide dioxygenase, $\mathrm{SO}=$ sulfite oxidase, $\mathrm{GSSH}=$ glutathione persulfide). Modified from Libiad et al. [65].

Under oxidative conditions, a fraction of $\mathrm{H}_{2} \mathrm{~S}$ can be scavenged by coordination to the heme-Fe(III) atoms of methemoglobin and metmyoglobin $[135,136]$ to form sulfhemoglobin (SulfHb) [128]. In mammals, metallo- and disulfide-containing macromolecules such as horseradish peroxidase and catalase and oxidized GSH also scavenge $\mathrm{H}_{2} \mathrm{~S}[137,138]$. Another mechanism for $\mathrm{H}_{2} \mathrm{~S}$ clearance is its complexation with other molecules (e.g., perthiols and nitrosothiols) that undergo removal by diffusion across respiratory or epithelial surfaces through metal- and enzyme-catalyzed oxidation [111,137].

\subsection{Reservoir of $\mathrm{H}_{2} \mathrm{~S}$}

Because $\mathrm{H}_{2} \mathrm{~S}$ and its metabolites (such as inorganic and organic persulfides and polysulfides, thiosulfate or metal-coordinated sulfur species) are highly reactive molecules [59], 
and sulfur species can spontaneously interconvert via fast dynamic equilibria, a dynamic system for controlled $\mathrm{H}_{2} \mathrm{~S}$ storage and release appears beneficial [26].

Evidence exists that $\mathrm{H}_{2} \mathrm{~S}$ could be stored and released as a response to a physiologic signal $[38,139]$. Two forms of sulfur stores in cells have been identified [140], namely, acidlabile sulfur, which releases $\mathrm{H}_{2} \mathrm{~S}$ under acidic conditions, and bound sulfane sulfur, which releases $\mathrm{H}_{2} \mathrm{~S}$ under reducing conditions [139]. Acid-labile sulfur consists of sulfur atoms in the iron-sulfur complexes, which play an important role in a wide range of redox reactions in enzymes of the respiratory chain in the mitochondria [139]. The critical $\mathrm{pH}$ below which $\mathrm{H}_{2} \mathrm{~S}$ is released from acid-labile sulfur is 5.4 [38]. Thus, this reaction is unavailable as a source of $\mathrm{H}_{2} \mathrm{~S}$ inside the mitochondrion, where $\mathrm{pH}>7.8$. Exogenously applied free $\mathrm{H}_{2} \mathrm{~S}$ is immediately absorbed and saved as bound sulfane sulfur, suggesting that probably enzymatically produced $\mathrm{H}_{2} \mathrm{~S}$ as described above may also be stored as bound sulfane sulfur [38]. In particular, $\mathrm{H}_{2} \mathrm{~S}$ produced by $3 \mathrm{MST}$ was reported to be stored as bound sulfane sulfur, which influences the intracellular bound sulfane sulfur concentration [105]. In turn, cells may release the stored $\mathrm{H}_{2} \mathrm{~S}$ after receiving a certain physiological signal, such as elevated $\mathrm{pH}$ [105]. Experimentally, the reducing activity of thiols such as GSH and cysteine is greater in alkaline conditions than at a neutral $\mathrm{pH}$. Therefore, most $\mathrm{H}_{2} \mathrm{~S}$ release from lysates of cultured neurons and astrocytes occurs at a $\mathrm{pH}$ higher than 8.4 [38].

\subsection{Antioxidant Functions of $\mathrm{H}_{2} \mathrm{~S}$}

As is the case with other gasotransmitters, $\mathrm{H}_{2} \mathrm{~S}$ exerts its functions by binding to biomolecules in a transient way as well as in a stable fashion via modification of their thiol groups. $\mathrm{H}_{2} \mathrm{~S}$ can exert antioxidant functions by induction of antioxidant pathways such as Keap1/Nrf2 that control glutathione biosynthesis [141-143], by persulfidation of cysteine residues in proteins [144-146], by acting on the mitochondrial respiratory chain to control ATP synthesis [147] and by direct reaction with metal centers [148], such as hemoglobin [116] and cytochrome c oxidase [47,149]. Direct reactions of $\mathrm{H}_{2} \mathrm{~S}$ with reactive oxygen species also occur, but given the low concentrations of $\mathrm{H}_{2} \mathrm{~S}$ in cells and tissues, this is unlikely to be a major contribution to overall antioxidant defense [150]. A recent comprehensive in vitro study identified nutraceutical polyphenols (berry extracts) that oxidize $\mathrm{H}_{2} \mathrm{~S}$ to potent antioxidant polysulfides that initiate cytoprotective effects [151]. The mechanism suggest that polyphenols undergo auto-oxidation to their corresponding semi-quinone species, and in turn react with $\mathrm{H}_{2} \mathrm{~S}$ to form thiyl radical and ultimately polysulfides and thiosulfate [151]. Increasing knowledge of the biochemistry of $\mathrm{H}_{2} \mathrm{~S}$ may be exploited for the design of dietary intervention studies aimed at augmenting antioxidant defense. Detailed reviews on the roles of $\mathrm{H}_{2} \mathrm{~S}$ in antioxidant functions with potential clinical relevance are available $[150,152-154]$. A review of chemical tools to study small molecule persulfides has also been published [155].

\section{Methods of Detection of Hydrogen Sulfide}

Because sulfur is a physicochemical and geological indicator, and hydrogen sulfide is a natural and anthropogenic pollutant [156], the first methods to detect $\mathrm{H}_{2} \mathrm{~S}$ were developed in the field of environmental chemistry, hence not suited for the analysis of the gasotransmitter in human and other animal samples.

As $\mathrm{H}_{2} \mathrm{~S}$ gained appreciation as a signaling molecule with important roles in human health, the development of methods to detect and quantify the gasotransmitter became a necessity and an exciting subfield of research. Methods based on fluorescence, polarography and chromatography were developed over the years, each carrying intrinsic advantages and disadvantages [156]. A summary of most commonly employed methods for the detection of $\mathrm{H}_{2} \mathrm{~S}$ in biological compartments is provided in Table 3. The accurate determination of $\mathrm{H}_{2} \mathrm{~S}$ concentrations in biological specimens remains a matter of active investigation. The major experimental challenge concerns the great reactivity of $\mathrm{H}_{2} \mathrm{~S}$ with numerous low and high molecular weight targets. As can be appreciated from the summary in Table 3 and the following sections, discrepancies still remain about what concentrations are free from 
unintended experimental artifacts, and which genuinely represent physiological ranges of $\mathrm{H}_{2} \mathrm{~S}$ concentration.

\subsection{Direct UV-Visible Spectrophotometric Measurement}

Two major spectrophotometric methods have been described for the measurement of $\mathrm{H}_{2} \mathrm{~S}$ : one direct, by looking at the absorbance of sulfide species in the UV region of the spectrum (214-300 nm) [157], and an indirect method that utilizes the $\mathrm{H}_{2} \mathrm{~S}$-binding hemoglobin from the marine organism Lucina pectinata, known as hemoglobin I [158].

The direct spectrophotometric method enables the determination of total dissolved sulfide concentration in natural waters through direct ultraviolet measurement of the HS ${ }^{-}$ ion [157]. Bisulfide concentration can be determined by measuring absorption from 214 to $300 \mathrm{~nm}$ and afterwards delimitation of the $\mathrm{HS}^{-}$spectra from the complex spectrum of the fluids [157]. In samples with a lower sulfide concentration, the spectrophotometric method enables simultaneous determination of other $\mathrm{UV}^{-}$absorbing ions such as nitrate, iodide and bromide. In order to have an exact measurement of bisulfide concentrations, samples should have low background absorption. Under these conditions, the detection limit is reported to be less than $1 \mu \mathrm{M}$ [157]. The advantages of this method are first and foremost simplicity and a fast data acquisition [157]. The optimal $\mathrm{pH}$ range for UV detection of total sulfide concentration lies in the range between 8.0 and 9.0 [157]. Alkaline conditions favor $\mathrm{HS}^{-}$formation, so bisulfide is more than $95 \%$ of total sulfide. An alkaline solution containing, e.g., $50 \mu \mathrm{M}$ total sulfide produces a well-defined absorbance peak at around $230 \mathrm{~nm}$ [157]. Several modifications of this method have been reported for the analysis of sewage and seawater [159-161], but of course, due to the complex composition of human and other animal samples, these approaches are not adequate for the quantification of $\mathrm{H}_{2} \mathrm{~S}$ in blood, tissue or other specimens $[157,162]$.

The indirect "zinc-trap" method is one of the oldest and most commonly applied techniques for the detection of $\mathrm{H}_{2} \mathrm{~S}$. It is based on the colorimetric detection of the end product methylene blue (MB) [163]. In the first step, sulfide is trapped with a metal (e.g., zinc acetate), followed by an acidification and reaction with $\mathrm{N}, \mathrm{N}$-dimethyl-p- phenylenediamine (DMPD). The next reaction, catalyzed by ferric chloride, generates the methylene blue dye that could be measured at $670 \mathrm{~nm}$ using a UV-spectrophotometer or a plate reader. Berliner et al. initially described this method with the main aim of measuring sulfide concentration in aquatic samples [163]. A disadvantage of the method and of colorimetric detection in general, is the possible interference of other chromophores present in the sample. Chromatographic separation was described to be a possible solution to this impurity and it could increase the sensitivity of the method [164-166]. A further improvement is the replacement of the UV-spectrophotometer detector with a mass spectrometer [167]. The detection limit was described as around $1 \mu \mathrm{M}$ [26]. Nevertheless, a deviation from linearity was observed at higher sulfide concentrations in the sample [26]. In addition, the methylene blue assay did not result in a well-defined $\mathrm{H}_{2} \mathrm{~S}$ peak $(660-680 \mathrm{~nm})$ at low physiological concentrations, in contrast to other analytical detection methods (e.g., HPLC detection of sulfide-dibimane) $[33,168]$.

Another indirect measurement of $\mathrm{H}_{2} \mathrm{~S}$ via its reaction with hemoglobin I was reported as a novel improvement of the UV-based spectrophotometric method [158]. This method is based on the high affinity and high specificity $1: 1$ coordination of $\mathrm{H}_{2} \mathrm{~S}$ and the ferric derivative of hemoglobin I ( $\mathrm{HbI}$ ) from the bivalve mollusk Lucina pectinata [158] (Figure 8a). The UV-visible spectrum of ferric $\mathrm{HbI}$ changes markedly upon binding to $\mathrm{H}_{2} \mathrm{~S}$ (Fe(III): $407-410 \mathrm{~nm}$; Fe(III)-SH: $419-425 \mathrm{~nm}$, Figure $8 \mathrm{~b}$ ), permitting the direct quantification of the gasotransmitter in solution at concentrations as low as $1 \times 10^{-6} \mathrm{M}[158,169]$. Ferric L. pectinata $\mathrm{HbI}$ can be purified directly from the clam or expressed in recombinant form in E. coli [170-172]. In both cases, $\mathrm{HbI}$ is utilized as a colorimetric probe to determine the concentration of pure, commercially available $\mathrm{H}_{2} \mathrm{~S}$. The concentration of $\mathrm{H}_{2} \mathrm{~S}$ is determined using the molar extinction coefficient for the sulfide-HbI complex $\Delta \varepsilon_{\text {tot }}=69.0 \mathrm{M}^{-1} \mathrm{~cm}^{-1}$ ) [158]. 


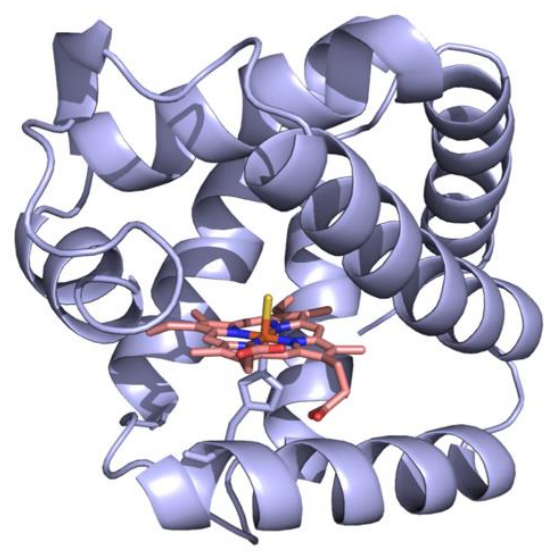

(a)

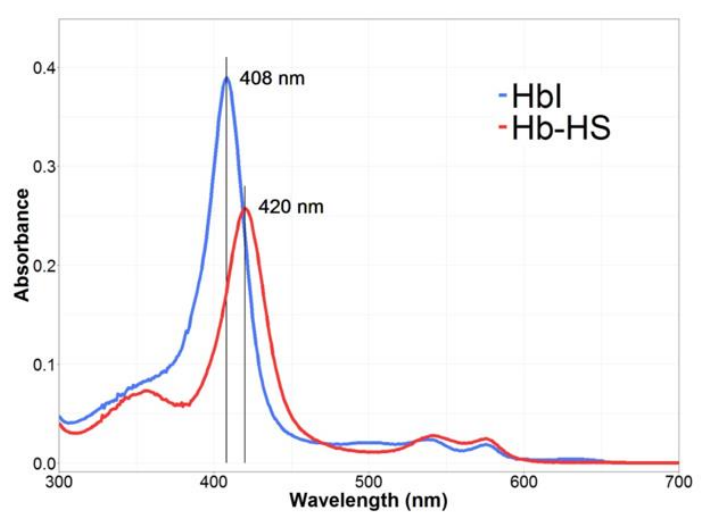

(b)

Figure 8. (a) Structure of $\mathrm{HbI}$ of Lucina pectinata bound to sulfide. (b) UV-visible spectra of hemoglobin I (10 $\mu \mathrm{M})$ before (blue) and after (red) addition of NaHS ( $1 \mathrm{mM}$, source of $\left.\mathrm{H}_{2} \mathrm{~S}\right)$ in $0.05 \mathrm{M}$ Tris buffer, $\mathrm{pH}=8.6$. Formation of the HbI-HS complex results in a red-shift in the UV-visible spectrum from 408 to $420 \mathrm{~nm}$ and hypochromy of the Soret band. Absorbance maxima are in agreement with data published in Boffi et al. [158].

\subsection{Chromatography}

A variety of chromatographic detection methods are available for the quantification of $\mathrm{H}_{2} \mathrm{~S}$ and, more generally, of sulfur pools [25]. The sections that follow summarize the most widely used chromatography-based methodologies and their applications.

\subsubsection{Gas Chromatography/Ion Chromatography}

Ubuka et al. reported a gas chromatography (GC) method that detects hydrogen sulfide and acid-labile sulfur in fresh rat liver and heart [37]. Hydrogen sulfide is trapped in an alkaline solution and determined by using gas chromatography coupled to a flame photometric detector (GC-FPD). In the gas transfer step, $\mathrm{H}_{2} \mathrm{~S}$ is collected from animal tissue samples. Acid-labile sulfur is liberated as hydrogen sulfide under acidic conditions [139] and sulfane sulfur is collected as thiocyanate by treating tissue samples with cyanide [173]. In the gas equilibration step, phosphoric acid is added to the specimen. Liberation of $\mathrm{H}_{2} \mathrm{~S}$ from the aqueous phase into the gas phase in the head space of a closed vial is induced by stirring of the sample. The head-space gas is then transferred to a gas chromatographer for measurement. According to the study, free hydrogen sulfide and sulfur dioxide could not be detected in the liver and heart with this gas chromatographic analysis. Therefore, they assumed that $\mathrm{H}_{2} \mathrm{~S}$ could be detected by ion chromatography after oxidation of hydrogen sulfide by hydrogen peroxide. The detection limit of this second step of sulfate and thiosulfate was reported as $20 \mathrm{pM}$ [37].

\subsubsection{Flow Gas Dialysis/Ion Chromatography}

The studies of Goodwin et al. described a very similar analytical technique to the above described chromatography for the determination of sulfide in human and rat brain tissue with a detection range of $100 \mu \mathrm{M}$ [41]. They used continuous flow gas dialysis as pre-treatment of the sample, followed by quantitation by ion chromatography with electrochemical detection. The advantage of this method is a pre-concentration of the analyte before the quantitation step. The continuous flow gas dialysis system separated sulfide from the homogenate matrix. The sample homogenate stream reacted with $\mathrm{HCI}$ in order to release the $\mathrm{H}_{2} \mathrm{~S}$ into a $\mathrm{NaOH}$ receiving solution. The receiving solution is collected in a vial and injected into the ion chromatograph. The electrochemical detector had a silver working electrode, a silver/silver chloride reference electrode and a stainless-steel counter electrode. This method is reported to be very selective and has until now no known interferences. Therefore, it could be a promising technique for the post-mortem 
analysis of $\mathrm{H}_{2} \mathrm{~S}$ concentrations in tissues from individuals who suffered from inhalation poisoning. Nevertheless, sample preparation is labor-intensive and quantification of $\mathrm{H}_{2} \mathrm{~S}$ by this method requires specialized instrumentation [41].

\subsubsection{Gas Chromatography/Chemiluminescence Sulfur Detector}

The combination of the described GC method with a chemiluminescence sulfur detector was reported to detect free $\mathrm{H}_{2} \mathrm{~S}$ concentration in liver and brain tissue of mice and human blood [32]. The detection limit is in the $\mathrm{nM}$ range [32]. A small gas sample is injected into a Teflon column packed with Chromosil 330, and nitrogen gas is used as a carrier with a flow rate of $25 \mathrm{~mL} / \mathrm{min}$. The concentration of $\mathrm{H}_{2} \mathrm{~S}$ could be determined via comparison of the peak areas of the unknown to those of known commercial standards. According to recent studies, very low concentrations of free $\mathrm{H}_{2} \mathrm{~S}$ could be measured in mouse brain tissue (14 $\mathrm{nM})$, liver tissue (17 $\mathrm{nM})$ and in human blood (100 pM) [32]. Levitt et al. used a different chemiluminescence sulfur detector and they were able to determine a concentration of $\mathrm{H}_{2} \mathrm{~S}$ in mouse blood of $15 \mathrm{nM}$ [34]. These findings highlight the marked variation introduced by different instrumentation and possibly by modification of the sample preparation step.

\subsubsection{Gas Chromatography with Silver Particles}

Ishigami et al. developed a GC-based method using silver particles to trap free $\mathrm{H}_{2} \mathrm{~S}$ from rat brain tissue homogenate [38]. The detection limit of this method was reported to be $9 \mu \mathrm{M}$ [48]. Small particles of silver absorb $\mathrm{H}_{2} \mathrm{~S}$ as $\mathrm{Ag}_{2} \mathrm{~S}$ from the biological sample. Proteins that adhere to silver particles are removed with Triton X100. Next, thiourea and $\mathrm{H}_{2} \mathrm{SO}_{4}$ are applied to release $\mathrm{H}_{2} \mathrm{~S}$ from silver sulfide produced on the surface of the particles. This procedure excludes the contribution of acid-labile sulfur. Nevertheless, no $\mathrm{H}_{2} \mathrm{~S}$ was detected because the detectable concentration in the brain is $\sim 9.2 \mu \mathrm{M}$ [38]. This result showed that under basal physiological conditions, free $\mathrm{H}_{2} \mathrm{~S}$ in the brain is maintained at a very low concentration. The concentration of $\mathrm{H}_{2} \mathrm{~S}$ released from homogenates of whole brain, liver and heart was measured at various $\mathrm{pH}$ values. The authors reported that the critical $\mathrm{pH}$ to release $\mathrm{H}_{2} \mathrm{~S}$ from acid-labile sulfur was $\sim 5.4$ [38].

In sum, a major disadvantage of the above described variations of the chromatography method are the multi-step sample preparation and the relatively long incubation times that are needed for gas evolution into the headspace of the collecting chromatography sample vial. These aspects pose a significant limitation, especially for real-time measurements of $\mathrm{H}_{2} \mathrm{~S}$ production [128]. These methods detect, first and foremost, $\mathrm{H}_{2} \mathrm{~S}$ gas alone instead of other bioavailable forms of sulfide (e.g., $\mathrm{HS}^{-}$, acid labile sulfide and bound sulfane sulfur). In that respect, these approaches are sensitive and specific for $\mathrm{H}_{2} \mathrm{~S}$ [26].

\subsubsection{High Pressure Liquid Chromatography (HPLC)}

The use of HPLC by several laboratories has permitted the development of methods that measure bioavailable sulfide in various forms. Savage and Gould reported on the derivatization of sulfide and separation by reversed-phase HPLC (RP-HPLC) coupled to spectrophotometric detection of methylene blue [174]. Zinc acetate was utilized to trap and determine $\mathrm{H}_{2} \mathrm{~S}$ concentration in acidic medium. Ogasawara et al. improved this HPLC method through pre-column fluorescence derivatization to detect trace amounts of sulfide [175]. After detection, those small sulfide quantities were converted into thionine, a fluorescent derivative. In a further step, sulfide reacted with $\mathrm{N}, \mathrm{N}$,-dimethyl-pphenylenediamine to methylene blue. This method has a detection limit in the micromolar range [175]. The HPLC method eliminates interferences that are problematic in spectrophotometric methods such as turbidity of the sample, the presence of impurities and the formation of colored byproducts [24].

Kožich et al. described an indirect measurement of $\mathrm{H}_{2} \mathrm{~S}$ biosynthesis by liquid chromatography-mass spectrometry (LC-MS/MS) [73]. The method examined end-point concentrations of the thioethers cystathionine (Cysta), homolanthionine (HLH) and lanthionine $(\mathrm{LH})$ as fingerprints of $\mathrm{H}_{2} \mathrm{~S}$ production in reactions driven by CBS. These thioethers 
are stable surrogate markers for $\mathrm{H}_{2} \mathrm{~S}$ biogenesis (Figure 4). The study determined thioether concentration in human plasma and in fibroblasts from patients with CBS deficiency, remethylation defects or nutritional vitamin B12 deficiency and compared them to the corresponding assessment in specimens from healthy controls. The detection of analytes was carried out using a commercially available kit for amino acid analysis, with mass spectrometry conditions set to positive electrospray ionization and selected multiple reaction monitoring. The detection limits for all three thioethers were approximately $1 \mathrm{nmol} / \mathrm{L}$.

\subsection{Monobromobimane Assay}

According to Wintner et al., the concentrations of reactive sulfide in saline and freshly drawn whole blood could be quantified through reactions with the thiol-specific derivatization agent monobromobimane (MBB), followed by reversed-phase fluorescence HPLC and/or mass spectrometry [35]. Monobromobimane has a high affinity for low molecular weight thiols [35]. This chemical probe undergoes nucleophilic substitution with sulfide, wherein two equivalents of MBB react with sulfide to form the highly fluorescent sulfide dibimane (Figure 9). As bimane itself is relatively hydrophobic, sulfide dibimane is even more hydrophobic than most monobimane derivatives of physiological thiols. Therefore, the sulfide dibimane species can be easily separated from other thiol bimane derivatives by reversed-phase chromatography (RP-HPLC).

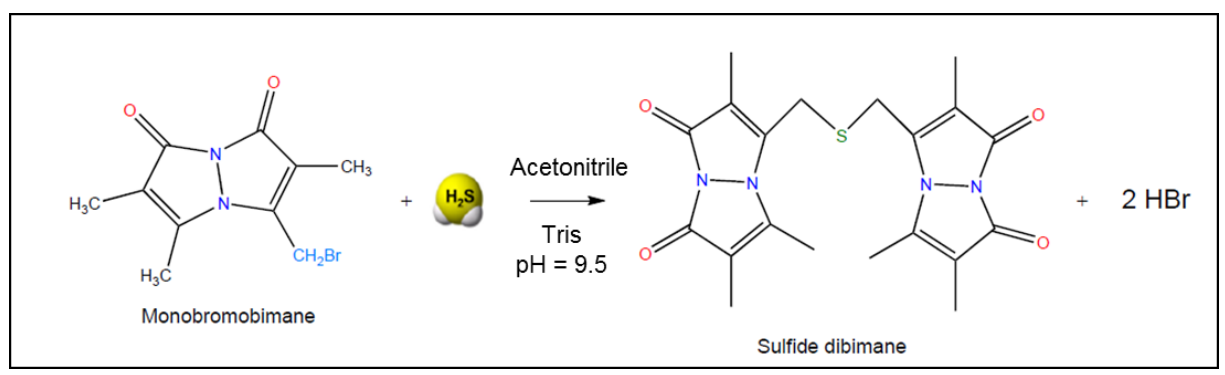

Figure 9. Monobromobimane derivatization reaction. Modified from Shen et al. [168].

In order to quantify the formation of sulfide dibimane in a sample, the next step is RP-HPLC with monitoring of UV absorption $(254 \mathrm{~nm})$ and fluorescence (lex $=390 \mathrm{~nm}$, lem $=475 \mathrm{~nm}$ ). In the studies by Wintner et al., formation of sulfide dibimane was followed by monitoring fluorescence intensity over 5 min [35].

Wintner et al. optimized assay conditions for the efficient and reproducible reaction of MBB with sulfide to form sulfide dibimane [35]. The assay is performed at room temperature, at $\mathrm{pH} 8.0$, and has a detection limit of $0.7 \mu \mathrm{M}$ free $\mathrm{H}_{2} \mathrm{~S}$ in rat blood [35]. Nevertheless, it is important to mention that the $\mathrm{MBB}$ assay measures all bioavailable sulfide, in the gas as well as in the anion form $\left(\mathrm{H}_{2} \mathrm{~S} / \mathrm{HS}^{-}\right)$. Since both forms are biochemically active, this assay quantifies $\mathrm{H}_{2} \mathrm{~S}$ bioequivalents relevant to physiology.

An improved protocol based on MBB with RP-HPLC and fluorescence detection was developed to determine $\mathrm{H}_{2} \mathrm{~S}$ speciation [33]. The method comprises selective liberation, trapping and derivatization of $\mathrm{H}_{2} \mathrm{~S}$. In the first step, acid-labile $\mathrm{H}_{2} \mathrm{~S}$ is liberated by incubating the sample under acidic conditions. Volatilized $\mathrm{H}_{2} \mathrm{~S}$ is then trapped and added to an excess of MBB. In a separate step, bound sulfane sulfur is incubated in the presence of the reducing agent TCEP. $\mathrm{H}_{2} \mathrm{~S}$ is again trapped and derivatized with MBB. Separation and quantification of the species by RP-HPLC and fluorescence detection were analogous to the protocol described above. Finally, the acid-labile pool was calculated by subtracting the concentration of free $\mathrm{H}_{2} \mathrm{~S}$ from the concentration of sulfide obtained by acid liberation. The bound sulfane sulfur pool was determined by subtracting the concentration of $\mathrm{H}_{2} \mathrm{~S}$ from the acid-liberation step alone from that of TCEP plus acidic conditions.

While the MBB method seems like an accurate, quantitative and scalable measurement of discrete pools of hydrogen sulfide from primary volatile sulfide pools, it is not free of limitations. Apart from the multiple experimental steps required to measure the concen- 
tration of $\mathrm{H}_{2} \mathrm{~S}$ both in solution and in its gaseous phase, carefully controlled studies of reactivity revealed that MBB itself modifies sulfur speciation in biological specimens such as plasma and serum $[26,59]$. The concentration of sulfide determined by the MBB method in serum samples was found to depend on incubation time and on the concentration of MBB itself [59]. These findings are in line with an independent report that compared sulfur quantitation side-by-side using MBB, iodoacetamide (IAM) and N-ethylmaleimide (NEM) [176]. The readout of sulfide concentration in whole blood was higher with probes NEM and MBB compared to the same measurement utilizing IAM [176]. These differences can be explained by a greater capacity of NEM and MBB in cleaving polysulfur chains compared to IAM. These limitations have lead experts in the field to recommend "extraordinary care" with the reporting of "free sulfide levels" and with the assignment of roles to specific sulfur species in biological systems [59].

\subsection{Other Fluorescent Probes for $\mathrm{H}_{2} \mathrm{~S}$ Detection}

Aside from the MBB-based methods, variants that employ other fluorescent probes have also been described [177]. One example is the use of benzodithiolone to determine the concentration of $\mathrm{H}_{2} \mathrm{~S}$ in plasma [177]. In order to detect $\mathrm{H}_{2} \mathrm{~S}$ selectively, the main aim was to distinguish $\mathrm{H}_{2} \mathrm{~S}$ from other biological nucleophiles, especially thiols such as glutathione and cysteine. In contrast to the other thiols, $\mathrm{H}_{2} \mathrm{~S}$ can undergo nucleophilic reaction twice. Cys and other thiols are monosubstituted and can therefore undergo the nucleophilic reaction only once. Benzodithiolone has a unique bis-electrophilic center, which could be a useful reagent for $\mathrm{H}_{2} \mathrm{~S}$ detection. Using this strategy, the concentration of $\mathrm{H}_{2} \mathrm{~S}$ could be measured in two ways: firstly, by following the fluorescent signal, and secondly, by the analysis of the benzodithiolone product (by mass spectrometry, for example).

Studies by Peng et al. described dansyl azide (DNS-Az), a novel reduction-sensitive, stable and non-fluorescent chemoprobe [178]. The reagent became fluorescent through reacting with sulfide. The reaction took place very rapidly, enabling the detection of transient changes in $\mathrm{H}_{2} \mathrm{~S}$ concentrations without any sample pre-treatment. Furthermore, the probe was simple in structure, very easy to synthesize and amenable to long-term storage.

Work by Thorson et al. described the utility of 7-azido-4-methylcoumarin (AzMC) for monitoring $\mathrm{H}_{2} \mathrm{~S}$ production by enzymatic sources and screening for potential inhibitors [179]. This fluorogenic probe presented a dynamic range of detection of $0.1-100 \mu \mathrm{M}$ and did not react with transsulfuration enzyme substrates Cys or Hcy at concentrations of $10 \mathrm{mM}$ nor with $1 \mathrm{mM}$ PLP or S-adenosylmethionine. However, the authors noted interference with the commonly used reducing agents DTT and TCEP. AzMC did not react with glutathione or 2-mercaptoethanol [179].

Another new fluorescent probe for $\mathrm{H}_{2} \mathrm{~S}$ detection is 4-methyl-2-oxo-2H-chromen-7-yl 5 -azidopentanoate (a self-immolative coumarin-based fluorescence probe) [40]. The design of this probe was based on the combination of two characteristic reactions performed by $\mathrm{H}_{2} \mathrm{~S}$ : firstly, the reduction of an azido group to an amine by $\mathrm{H}_{2} \mathrm{~S}$, and secondly, a spontaneous intramolecular lactamization, concomitant to the formation of highly fluorescent 7-hydroxy-4-methylcoumarin (also known as 4-methylumbelliferone and hymecromone). The advantages of this probe were described as follows: the synthesis and purification steps were straightforward, the substance reacted rapidly (within seconds, end-point imaging of $\mathrm{H}_{2} \mathrm{~S}$-formation could be possible), the substance was chemically stable which could enable a long-term storage, it showed a linear concentration-signal relationship at relevant $\mathrm{H}_{2} \mathrm{~S}$ concentrations and it was stable in aqueous solutions, especially at physiological $\mathrm{pH}$. The optimal $\mathrm{pH}$ was described as around $\approx 7.0$, which is comparable with the $\mathrm{pH}$ of many mammalian body fluids. The benefit of this substance in comparison to other fluorogenic assays was that self-immolative probes generate a more stable signal with a higher signal-to-noise ratio [40].

Dulac et al. described a selective and reversible fluorescent system to detect hydrogen sulfide [156]. The competitive detection limit was claimed to be $\sim 200 \mathrm{nM}$ at pH 7.4 [156]. 
Firstly, they looked for an avid biological system for hydrogen sulfide as a sensor. This unique characteristic could be found in hemoglobin $\mathrm{HbI}$ from the clam Lucina pectinata [169]. As described above, the high affinity to $\mathrm{HbI}$ for $\mathrm{H}_{2} \mathrm{~S}$ could be explained by the special structure of its distal active site which contains the amino acids glutamine and two phenylalanines [135]. Therefore, $\mathrm{HbI}$ appeared to be perfectly suited for the biomolecular gating approach. In the first step, Dulac et al. developed a turn-on fluorescent sensor in order to detect $\mathrm{H}_{2} \mathrm{~S}$, with $\mathrm{N}$-[2(2-hydroxyethoxy)ethyl]-6,8-difluoro-7-hydroxycoumarin-3carboxamide, a derivative of 6,8-Difluoro-7-hydroxycoumarin-3-carboxylic acid, the latter known as "Pacific Blue" [180]. Afterwards, increasing concentrations of rHbI were added to the chemical fluorophore, which resulted in a decrease in fluorescence intensity. Addition of the $\mathrm{H}_{2} \mathrm{~S}$ source sodium hydrosulfide $(\mathrm{NaSH})$ restored the fluorescence of the fluorophore, which was indicative of a direct reaction between the derivative of the coumarin dye Pacific Blue and $\mathrm{H}_{2} \mathrm{~S}$. Indeed, after the reaction took place, Dulac et al. observed a red-shift of the Soret band from 407 to $425 \mathrm{~nm}$, which is characteristic of the Hb-SH complex. This result showed a measurable modulation of the photophysical characteristics of a fluorophore with an appropriate excitation around $407 \mathrm{~nm}$. The presence of the fluorophore led to faster coordination of $\mathrm{H}_{2} \mathrm{~S}$ to $\mathrm{rHbI}$ and a faster dissociation as well with respect to so far published data. In particular, the dissociation measurements revealed a discrepancy with previously reported rates (half-life around $92 \mathrm{~s}$ [156], previously reported around $600 \mathrm{~s}$ [169]). Unfortunately, the measurement of $\mathrm{H}_{2} \mathrm{~S}$ in human plasma was not possible, which indicated that $\mathrm{H}_{2} \mathrm{~S}$ concentration in plasma samples could be lower than the quantification limit.

In summary, these fluorescent $\mathrm{H}_{2} \mathrm{~S}$ detection methods appear simple and cost-effective. Possible limitations may exist in terms of sensitivity (micromolar) and the time needed to sufficiently measure changes in $\mathrm{H}_{2} \mathrm{~S}$ concentration (minutes to an hour). Finally, this technical approach does not detect sulfide concentrations from different biochemical pools within the sample or the fraction of $\mathrm{H}_{2} \mathrm{~S}$ bound to proteins $[33,168]$.

\subsection{Sulfide Specific Ion-Selective Electrodes (ISE)}

In these methods, the measurement of $\mathrm{H}_{2} \mathrm{~S}$ concentration is performed against a glass $\mathrm{pH}$ electrode, upon conversion of all sulfide to $\mathrm{S}^{2-}$. The resulting electromotive force depends on sulfide concentration and on the $\mathrm{pH}$ of the solution as well [181]. The latter is kept constant and alkaline, to ensure full conversion of all sulfide species to $\mathrm{S}^{2-}$. A calibration curve made with commercially available sources of $\mathrm{H}_{2} \mathrm{~S}$ is utilized for quantification.

Whitfield et al. demonstrated an erroneous effect of ISEs using trout plasma and bovine serum albumin (BSA) samples [182]. The authors observed that sulfide concentration in their samples increased rapidly over time because of alkaline conditions. Searcy and Lee reported in an earlier study the detection limit to be around $0.5 \mu \mathrm{M}$ and claimed that the electrode could work accurately both in oxygenated and deoxygenated buffers [110]. Searcy and Peterson demonstrated the sensitivity of this method, maintaining a linear response in a very low $(1 \mathrm{fM}-1 \mu \mathrm{M})$ concentration range [183]. Further described advantages of the method were as follows: it measured free sulfide concentration without a previous sulfide derivatization and it enabled a dynamic measurement due to fast electrode response. Nevertheless, the risk for erroneous measurements is still substantial, most likely because of harsh sample pre-treatment and because of an interference with the $\mathrm{Ag}^{+} / \mathrm{Ag}_{2} \mathrm{~S}$ system on the electrode surface $[25,26]$.

\subsection{Polarographic Electrodes}

Polarographic electrodes are reliable for end-point $\mathrm{H}_{2} \mathrm{~S}$ gas detection in biological samples [36]. The detection limit is reported to be in the $\mathrm{nM}$ range under anoxic conditions. Koenitzer et al. developed a novel polarographic hydrogen sulfide sensor (PHSS) [36], which is able to record $\mathrm{H}_{2} \mathrm{~S}$ concentration in a respirometer chamber or in vessels [184]. The design contained an anode, cathode and a $\mathrm{H}_{2} \mathrm{~S}$-permeable polymer membrane. The PHSS has high affinity for $\mathrm{H}_{2} \mathrm{~S}$, responds quickly to varying $\mathrm{H}_{2} \mathrm{~S}$ concentration and has 
a detection limit of approximately $10 \mathrm{nM}$ [36]. The PHSS provided satisfactory response to the kinetic profile of $\mathrm{H}_{2} \mathrm{~S}$ metabolism, which enabled measurements in cell lysates, cell suspensions, intact tissues and whole organisms. Due to high selectivity, PHSS could be combined with other end-point polarographic sensors, e.g., for $\mathrm{O}_{2}$ (POS) and NO (PNOS), in order to detect a possible interaction of these factors with $\mathrm{H}_{2} \mathrm{~S}$ in biological systems. With such a multisensor respirometry, Doeller et al. demonstrated end-point formation and consumption of $\mathrm{H}_{2} \mathrm{~S}$ by mammalian tissues and cultured cells [36].

A recent report by Faccenda et al. showed that polydimethylsiloxane (PDMS) membranes were permeable to $\mathrm{H}_{2} \mathrm{~S}$ and could therefore be useful for continuous $\mathrm{H}_{2} \mathrm{~S}$ determination [185]. In addition, 96-well inserts constructed of PDMS functioned as a $\sim 100 \mu \mathrm{m}$ thick $\mathrm{H}_{2} \mathrm{~S}$-permeable membrane, which was not permeable to other thiols. Therefore, nonspecific thiols could simply be eliminated. The group reported a detection limit of around $\sim 0.51 \mu \mathrm{M}$ for free $\mathrm{H}_{2} \mathrm{~S}$ (as solution sulfide) [185]. Although this $\mathrm{H}_{2} \mathrm{~S}$ polarographic sensor method is sensitive and accurate, it does not detect other biochemical forms of sulfide (e.g., acid labile and bound sulfide). Nevertheless, the PDMS method seems to be the best option for end-point detection of $\mathrm{H}_{2} \mathrm{~S}$ gas formation.

Table 3. Methods of detection of hydrogen sulfide.

\begin{tabular}{|c|c|c|c|c|}
\hline Method & Sample Pre-Analytics & Limit of Detection & Type of Sample & Literature \\
\hline \multicolumn{5}{|l|}{$\begin{array}{l}\text { 1. Direct spectrophotometric } \\
\text { measurement }\end{array}$} \\
\hline $\begin{array}{l}\text { 1.1. Direct ultraviolet detection of the } \\
\text { HS }^{-} \text {ion, absorption measurement } \\
\text { from } 214 \text { to } 300 \mathrm{~nm} \text { (peak around } \\
230 \mathrm{~nm} \text { ) }\end{array}$ & $\begin{array}{l}\text { Sulfide dissolved in natural } \\
\text { water, } \mathrm{pH} \sim 8.0\end{array}$ & $<1 \mu \mathrm{M}$ & $\begin{array}{c}\text { Dissolved } \\
\text { sulfide in } \\
\text { natural waters }\end{array}$ & [157] \\
\hline $\begin{array}{l}\text { 1.2. Zinc trap/methylene blue: } \\
\text { Trapping sulfide with a metal (e.g., } \\
\text { zinc acetate) with subsequent } \\
\text { acidification and reaction with DMPD, } \\
\text { formation of methylene blue by a } \\
\text { ferric chloride catalyzed reaction, } \\
\text { spectrophotometric measurement of } \\
\text { methylene blue, improvement by } \\
\text { replacing the spectrophotometer } \\
\text { detector with a mass spectrometer }\end{array}$ & $\begin{array}{l}\text { No pre-treatment of sulfide } \\
\text { is necessary }\end{array}$ & $\begin{array}{c}1 \mu \mathrm{M} \\
50 \mathrm{ng} \mathrm{L}^{-}\end{array}$ & $\begin{array}{l}\text { Aquatic sample } \\
\text { PSI particles }\end{array}$ & [163-167] \\
\hline $\begin{array}{l}\text { 1.3. Hemoglobin I. Based on the } 1: 1 \\
\text { reaction between } \mathrm{H}_{2} \mathrm{~S} \text { and the ferric } \\
\text { species of hemoglobin } \mathrm{I}(\mathrm{HbI}) \text {,simple } \\
\text { and fast, measuring of absorbance at } \\
408 \mathrm{~nm} \text { and } 429 \mathrm{~nm} \text {, determination of } \\
\text { the fractional saturation of } \\
\text { HbI- } \mathrm{H}_{2} \mathrm{~S} \text { complex }\end{array}$ & $\begin{array}{l}\text { Purification of ferric } L \text {. } \\
\text { pectinata } \mathrm{HbI} \text { from the clam, } \\
\text { determination of } \mathrm{HbI} \\
\text { concentration, } \mathrm{H}_{2} \mathrm{~S} \text { of } \\
\text { analytical grade was used } \\
\text { without further } \\
\text { purification, calculation of } \\
\text { solubility of } \mathrm{H}_{2} \mathrm{~S}\end{array}$ & Up to $n M$ & $\begin{array}{c}\text { Ferric } L \text {. } \\
\text { pectinata } \mathrm{HbI} \text {, } \\
\text { dissolved } \mathrm{H}_{2} \mathrm{~S} \\
\text { of analytical } \\
\text { grade }\end{array}$ & {$[158,169]$} \\
\hline \multicolumn{5}{|l|}{ 2. Chromatography } \\
\hline $\begin{array}{l}\text { 2.1. Gas chromatography/ion } \\
\text { chromatography: Determination of } \\
\mathrm{H}_{2} \mathrm{~S} \text { using an } \mathrm{A} 7 \text { column equipped } \\
\text { with a flame photometric detector } \\
\text { (GC-FPD)/quantitation with } \\
\text { electrochemical detection }\end{array}$ & $\begin{array}{l}\text { Tissues are treated with } \\
\text { acid to liberate } \mathrm{H}_{2} \mathrm{~S} \text { from } \\
\text { ALS, sulfane sulfur is } \\
\text { liberated as thiocyanate by } \\
\text { treating tissues with } \\
\text { cyanide, homogenization } \\
\text { with sodium } \\
\text { chloride/oxidation of } \\
\text { hydrogen sulfide by } \\
\text { hydrogen peroxide }\end{array}$ & $>100 \mathrm{~nm} / \mathrm{g}$ & $\begin{array}{l}\text { Rat liver and } \\
\text { heart tissues }\end{array}$ & [37] \\
\hline
\end{tabular}


Table 3. Cont.

\begin{tabular}{|c|c|c|c|c|}
\hline Method & Sample Pre-Analytics & Limit of Detection & Type of Sample & Literature \\
\hline $\begin{array}{c}\text { 2.2. Flow gas dialysis/ion } \\
\text { chromatography: Separation of } \\
\text { sulfide from the homogenate matrix } \\
\text { enables a } \\
\text { pre-concentration/electrochemical } \\
\text { detection and quantitation of } \mathrm{H}_{2} \mathrm{~S} \\
\text { through a silver working electrode, a } \\
\text { silver/silver chloride reference } \\
\text { electrode and a stainless-steel } \\
\text { counter electrode }\end{array}$ & $\begin{array}{l}\text { Fatal intoxication of the } \\
\text { brain by intraperitoneal } \\
\text { injection of NaHS, } \\
\text { homogenization with } \\
\mathrm{NaOH} \text {, reaction of the } \\
\text { homogenate with } \mathrm{HCl} \text { to } \\
\text { release } \mathrm{H}_{2} \mathrm{~S}\end{array}$ & $100 \mu \mathrm{M}$ & $\begin{array}{l}\text { Human and rat } \\
\text { brain tissue }\end{array}$ & [41] \\
\hline $\begin{array}{l}\text { 2.3. Gas chromatogra- } \\
\text { phy/chemiluminescence: Injection of } \\
\text { a gas sample onto a Teflon column, } \\
\text { determination of } \mathrm{H}_{2} \mathrm{~S} \text { concentration } \\
\text { via comparison of peak area of the } \\
\text { unknown to that of known standards }\end{array}$ & $\begin{array}{l}\text { Incubation of homogenized } \\
\text { tissue in media, } \\
\text { homogenization in ice-cold } \\
\text { potassium phosphate } \\
\text { buffer, addition of aliquots } \\
\text { of the tissue homogenate to } \\
\text { pre-warmed } \\
\text { polypropylene syringes }\end{array}$ & $\begin{array}{c}17 \mathrm{nM} \\
14 \mathrm{nM} \\
100 \mathrm{pM}\end{array}$ & $\begin{array}{l}\text { Liver tissue } \\
\text { Brain tissue of } \\
\text { mice } \\
\text { Human blood }\end{array}$ & [32] \\
\hline $\begin{array}{l}\text { 2.4. Gas chromatography/silver } \\
\text { particles: } \\
\text { Adsorption of } \mathrm{H}_{2} \mathrm{~S} \text { as } \mathrm{Ag}_{2} \mathrm{~S} \text { through } \\
\text { silver particles from the sample, } \\
\text { application of thiourea and } \mathrm{H}_{2} \mathrm{SO}_{4} \text { to } \\
\text { protein-free silver particles to release } \\
\mathrm{H}_{2} \mathrm{~S} \text { from silver sulfide produced on } \\
\text { the surface of the particles, } \\
\text { measurement of } \mathrm{H}_{2} \mathrm{~S} \text { concentration at } \\
\text { various pH values with } \mathrm{GC}\end{array}$ & $\begin{array}{l}\text { Alkalinization of the } \\
\text { cytoplasm for } \mathrm{H}_{2} \mathrm{~S} \text { release } \\
\text { from bound sulfur, } \\
\text { acid-labile sulfur: } \\
\text { homogenization of rat } \\
\text { tissues with } \mathrm{NaOH}, \\
\text { neutralization of cleared } \\
\text { supernatant with } \\
\text { phosphoric acid, } \\
\text { bound sulfur: } \\
\text { homogenization of rat or } \\
\text { mouse tissue with a } \\
\text { polytron homogenizer in } \\
\text { ice-cold buffer, addition of } \\
\text { DTT to supernatant }\end{array}$ & $\begin{array}{l}15 \mathrm{nM} \\
9 \mu \mathrm{M} \\
6 \mathrm{pM}\end{array}$ & $\begin{array}{c}\text { Mouse blood } \\
\text { Rat brain } \\
\text { Rat homogenate } \\
\text { tissue }\end{array}$ & {$[34,38]$} \\
\hline $\begin{array}{l}\text { 2.5. Liquid chromatography-mass } \\
\text { spectrometry: Measurement of CBS } \\
\text { activity, using the stable isotope } \\
\text { substrate } \\
\text { 2,3,3-2H serine, monitoring of } \\
\text { 3,3-2H-cystathionine, cystathionine } \\
\text { and } 3,3,4,4-2 \mathrm{H} \text {-labeled cystathionine } \\
\text { formation }\end{array}$ & $\begin{array}{l}\text { Addition of pyridoxine to } \\
\text { all plasma samples at the } \\
\text { time of sampling, addition } \\
\text { of plasma or serum to a } \\
\text { solution containing Tris- } \\
\text { pyridoxal 5'-phosphate } \\
\text { and 2,3,3-2H-labeled serine, } \\
\text { activation of CBS by SAM }\end{array}$ & Up to $n M$ & $\begin{array}{l}\text { Human plasma } \\
\text { or serum }\end{array}$ & [186] \\
\hline
\end{tabular}

2.6. Modification of liquid chromatography-mass spectrometry:

Optimization of liquid chromatography with a commercially available Symmetry C18 column and No difference $0.1 \mu \mathrm{M}$ Human plasma or serum 
Table 3. Cont.

\begin{tabular}{|c|c|c|c|c|}
\hline Method & Sample Pre-Analytics & Limit of Detection & Type of Sample & Literature \\
\hline $\begin{array}{l}\text { 2.7. HPLC:(2.7.1) Derivatization of } \\
\text { sulfide via reversed-phase HPLC } \\
\text { (RP-HPLC) separation, determination } \\
\text { of sulfide via spectrophotometric } \\
\text { detection of methylene blue, trapping } \\
\text { of } \mathrm{H}_{2} \mathrm{~S} \text { with zinc acetate, measuring of } \\
\mathrm{H}_{2} \mathrm{~S} \text { concentration under } \\
\text { acidic conditions }\end{array}$ & $\begin{array}{l}\text { Addition of zinc acetate to } \\
\text { each rumen fluid sample, } \\
\text { homogenization of } \\
\text { cerebrocortical gray matter } \\
\text { in aqueous zinc acetate, } \\
\text { treatment of human whole } \\
\text { blood with heparin, } \\
\text { preparation of spiked } \\
\text { samples by adding sulfide } \\
\text { standard solutions, } \\
\text { conversion into the } \\
\text { fluorescent derivative } \\
\text { thionine, under acidic } \\
\text { conditions }\end{array}$ & $\begin{array}{c}0.123 \text { to } 0.189 \mathrm{pmol} \\
\mathrm{dm}^{-3}\end{array}$ & $\begin{array}{l}\text { Bovine brain } \\
\text { tissue }\end{array}$ & [174] \\
\hline
\end{tabular}

(2.7.2) Separation of sulfide on a reversed-phase column and fluorimetrical detection, after pre-column fluorescence derivatization, conversion of low sulfide concentration into thionine, formation of methylene blue

\section{Monobromobimane assay (gold} standard)

3.1. Reaction with the thiol-specific derivatization agent monobromobimane to sulfide-dibimane, detection of sulfide-dibimane concentration by reversed-phase fluorescence HPLC and/or mass spectrometry

3.2. Monobromobimane method coupled with RP-HPLC and fluorescence detection, measurement of sulfide by methylene blue
Reaction of sulfide with 2.0 equivalents of monobromobimane, formation of sulfide-dibimane

Human red blood cells
Liberation of acid-labile

$\mathrm{H}_{2} \mathrm{~S}$ by incubation of the sample in an acidic solution ( $\mathrm{pH}$ 2.6) with diethylenetriaminepentaacetic acid (DTPA), incubation of the sample with TCEP

\section{Fluorescent probes}

\subsection{Conductometric gas nanosensors} for $\mathrm{H}_{2} \mathrm{~S}$, which are synthesized by electrodepositing gold nanoparticles on single-walled carbon nanotube (SWNT) networks, detection of $\mathrm{H}_{2} \mathrm{~S}$ is based on conductivity changes of thin films upon exposure to $\mathrm{H}_{2} \mathrm{~S}$ gas

4.2. Measurement of $\mathrm{H}_{2} \mathrm{~S}$ plasma concentration by assessing the fluorescence signal from

benzodithiolone product formation. Benzodithiolone has a bis-electrophilic center with specificity for $\mathrm{H}_{2} \mathrm{~S}$ detection
Hydrogen sulfide (purity:

$99.998 \%$ ) diluted in dry air at a gas flow of $200 \mathrm{std}$.

$3 \mathrm{ppb} \quad \mathrm{H}_{2} \mathrm{~S}$ gas

[188] $\mathrm{cm} \sim 3 \mathrm{~min}^{-1}$
[35]

plasma

Mouse plasma

$\begin{array}{lc}\text { Preparation of the probe } & \\ \text { with thiosalicylic acid, } & \text { Reactive } \\ \text { preparation of } & \text { disulfide- } \\ \text { bovineplasma containing } & \text { containing } \\ \text { NaHS at different } & \text { probeBovine- } \\ \text { concentrations }(0,50,100 & \text { plasma } \\ \text { and } 500 \mathrm{~mm}) & \end{array}$


Table 3. Cont.

\begin{tabular}{|c|c|c|c|c|}
\hline Method & Sample Pre-Analytics & Limit of Detection & Type of Sample & Literature \\
\hline $\begin{array}{l}\text { 4.3. Dansyl azide (DNS-Az) is a } \\
\text { reduction-sensitive, stable, } \\
\text { non-fluorescent chemoprobe, it } \\
\text { becomes fluorescent upon reacting } \\
\text { with sulfide }\end{array}$ & No sample pre-treatment & $\begin{array}{l}1 \mu \mathrm{M} \\
5 \mu \mathrm{M}\end{array}$ & $\begin{array}{l}\text { Aqueous } \\
\text { solution } \\
\text { Bovine } \\
\text { serumMouse } \\
\text { blood }\end{array}$ & [178] \\
\hline $\begin{array}{l}\text { 4.4. 7-azido-4-methylcoumarin } \\
\text { (AzMC) is a fluorogenic } \\
\text { probe selective for H2S; it provides a } \\
\text { facile, direct, continuous and sensitive } \\
\text { assay for activity monitoring of } \\
\text { PLP-dependent } \\
\text { enzymes }\end{array}$ & $\begin{array}{l}\text { Synthesis and purification } \\
\text { of hCBS }\end{array}$ & $0.1 \mu \mathrm{M}$ & $\begin{array}{l}\text { Truncated } \\
\text { version of } \\
\text { human CBS } \\
\text { (without the } \\
\text { regulatory } \\
\text { domain) }\end{array}$ & [179] \\
\hline
\end{tabular}

\subsection{4-methyl-2-oxo-2H-chromen-7-yl} 5-azidopentanoate, a fluorescent probe for $\mathrm{H}_{2} \mathrm{~S}$ detection, two characteristic reactions of $\mathrm{H}_{2} \mathrm{~S}$ : reduction of an azido group to an amine, intramolecular lactamization with simultaneous release of highly fluorescent

7-hydroxy-4-methylcoumarin

\subsection{N-[2(2-hydroxyethoxy)ethyl]-6,8- difluoro-}

7-hydroxycoumarin-3-carboxamide

is a turn-on fluorescent sensor to detect $\mathrm{H}_{2} \mathrm{~S}$, the sensor $\mathbf{r H b I}$ functions as a filter at the excitation wavelength of fluorophore in absence of $\mathrm{H}_{2} \mathrm{~S}$, but not in its presence, permits end-point measurement of $\mathrm{H}_{2} \mathrm{~S}$ concentration, reversible and selective
Saliva samples were tested instantly, measurements do not require any chemical pre-treatment, aqueous medium at $\mathrm{pH}=7.4$
Sodium

phosphate

buffer at

physiological

pHSaliva
[40]

Expression of recombinant

$\mathrm{rHbI}$ in E. coli BLi5 strain,

purification of recombinant

$\mathrm{rHbI}, \mathrm{UV}-$ vis spectrum to

confirm the formation of

$1.641-7.124 \mu \mathrm{M}$
$\mathrm{rHbI}-\mathrm{H}_{2} \mathrm{~S}$, adding of

potassium cyanide to the reaction mixture, monitoring of

$\sim 200 \mathrm{nM}$ at pH 7.4 $\begin{gathered}\text { Recombinant } \\ \text { hemoglobin I } \\ \text { from Lucina } \\ \text { pectinata } \\ \text { Human plasma }\end{gathered} \quad[156,180]$

displacement reaction by

$\mathrm{UV}-$ vis spectroscopy

\section{Sulfide specific ion-selective} electrodes

Measurement against a glass $\mathrm{pH}$ electrode, ISEs measure the $\mathrm{HS}^{-}$form of sulfide in an alkaline environment to favor $\mathrm{HS}^{-}$formation
Samples placed in alkaline

buffer, saturated solutions of sparingly soluble metal salts

\section{Polarographic electrodes}

6.1. PHSS records the concentration in a respirometer chamber/vessel, selective for $\mathrm{H}_{2} \mathrm{~S}$, responds rapidly to varying $\mathrm{H}_{2} \mathrm{~S}$ concentrations, contains a $\mathrm{H}_{2} \mathrm{~S}$-permeable polymer membrane

\subsection{Polydimethylsiloxane (PDMS)} membranes are permeable to $\mathrm{H}_{2} \mathrm{~S}$, a continuous measurement of $\mathrm{H}_{2} \mathrm{~S}$ is possible, not permeable for
Injection of supernatant

into the respirometer chamber containing PBS, addition of the substrate L-cysteine and the cofactor PLP to support the activity of enzymes CBS and CSE
Rat aorta Smooth muscle cellsIntact rat thoracicaorta

\section{[36]}

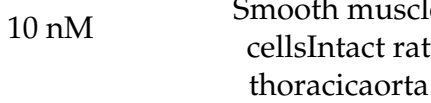

Bovine serum albumin (BSA) 


\section{Determination of Hydrogen Sulfide Production in Genetic Diseases of Sulfur Metabolism}

Inborn errors of metabolism represent a heterogeneous group of at least 700 rare diseases, which are caused by inherited deficiencies of enzymes, transporters and other gene products $[189,190]$. Genetic defects in sulfur amino acid metabolism lead to an accumulation of the metabolite homocysteine, due to a blockade in the transsulfuration or remethylation pathways. Many in-depth studies described naturally occurring mutations, protein structures and consequences for metabolism and phenotype. Despite its informative value in terms of residual enzyme activity and the clinical presentation of patients with inborn errors that impair $\mathrm{H}_{2} \mathrm{~S}$-pathways, very few published works determined the concentration of product $\mathrm{H}_{2} \mathrm{~S}$ or examined its potential contribution to pathogenesis. A summary of $\mathrm{H}_{2} \mathrm{~S}$ concentrations determined in different genetic diseases of metabolism is presented in the sections below, covering both human and animal studies. Main findings from studies where $\mathrm{H}_{2} \mathrm{~S}$ was measured are also provided in Table 4. All enzymes described in section $\mathrm{B}$, which take part in the biogenesis and the catabolism of sulfur amino acids, can carry an inborn mutation and therefore lead to homocystinuria. For example, 177 missense mutations have been found in the human CBS gene [191], many of which present decreased activity [192], which could also imply impaired $\mathrm{H}_{2} \mathrm{~S}$ homeostasis.

\section{1. $\mathrm{H}_{2} \mathrm{~S}$ Metabolism in Human Studies}

Studies by Kožich et al. determined sulfur species in patients with two different types of homocystinuria [42]. The first group consisted of patients with the severe CBS deficiency (CBSD), who do not respond to intervention with pyridoxine, while the second group included patients with remethylation defects (RMD), who often present with a more moderate form of homocystinuria. In the samples of patients with CBSD, homocysteine and methionine accumulated while metabolites below the CBS block (i.e., cystathionine and cysteine) were decreased. In contrast, patients with RMD exhibited decreased production of methionine and S-adenosylmethionine, an accumulation of Hcy and an increased flux of sulfur compounds through the transsulfuration pathway as indicated by the accumulation of cystathionine. Plasma sulfide concentration was determined using monobromobimane (MBB) derivatization followed by HPLC separation and fluorescent quantitation of the sulfide dibimane (SDB) product as described in previous publications [33,35]. This study employed two slightly different experimental settings in order to measure different fractions of the bound sulfide pool (based on the use of different MBB concentrations, which affects the kinetics of sulfide release) beside free sulfide. Both methods indicated that sulfide concentration in plasma of CBSD patients $\left(0.65 \mu \mathrm{M} \mathrm{L}^{-1} / 0.15 \mu \mathrm{M} \mathrm{L}^{-1}\right)$ did not differ from those of the control PKU (phenylketonuria) group $\left(0.5 \mu \mathrm{M} \mathrm{L}^{-1} / 0.19 \mu \mathrm{M} \mathrm{L}^{-1}\right)$. Surprisingly, the measured median sulfide concentrations in plasma of patients with RMD were reported to be significantly decreased to $53 \%$ and $64 \%$ of the median in healthy controls (RMD: $0.32 \mu \mathrm{M} \mathrm{L}^{-1} / 0.12 \mu \mathrm{M} \mathrm{L}^{-1}$, controls: $0.6 \mu \mathrm{M} \mathrm{L}^{-1} / 0.2 \mu \mathrm{M} \mathrm{L}^{-1}$ ) [42]. One possible interpretation of these results is that patients with CBSD may have produced slightly less $\mathrm{H}_{2} \mathrm{~S}$ from Cys, which was compensated by production of $\mathrm{H}_{2} \mathrm{~S}$ from Hcy by CSE and other enzymes, and that this slightly higher $\mathrm{H}_{2} \mathrm{~S}$ is further metabolized to thiosulfate.

Studies on $\mathrm{H}_{2} \mathrm{~S}$ production with variant p.P49L of human CBS demonstrated a 3-fold reduction $\left(0.9 \mathrm{~mol} \mathrm{H}_{2} \mathrm{~S}\right.$ mol CBS ${ }^{-1} \mathrm{~min}^{-1}$ versus $\left.0.3 \mathrm{~mol} \mathrm{H}_{2} \mathrm{~S} \mathrm{~mol} \mathrm{CBS}^{-1} \min ^{-1}\right)$ of $\mathrm{H}_{2} \mathrm{~S}$ production compared to wild type CBS [193]. The concentration of $\mathrm{H}_{2} \mathrm{~S}$ was measured either by amperometry using a $\mathrm{H}_{2} \mathrm{~S}$-selective electrode or by the lead acetate method [97]. Additionally, they wanted to evaluate by UV-visible absorption spectroscopy the impact of this mutation on the protein redox spectra. First, they measured the $\mathrm{H}_{2} \mathrm{~S}$ production of the canonical CBS reaction with Cys and Hcy as substrate in the absence of PLP (PLP"untreated"). Under these conditions, the basal activity of the p.P49L mutant was more than 3-fold lower than that of the WT enzyme. In contrast, addition of SAM resulted in similar readouts of $\mathrm{H}_{2} \mathrm{~S}$ synthesis in WT and mutant p.P49L. Secondly, Vicente et al. purified the variant in the presence of PLP (PLP-"treated") and reported CBS activity similar to the WT 
enzyme, despite presenting impaired activity stimulation by SAM [193]. Furthermore, they analyzed the structure of the p.P49L variant in detail and discovered a higher flexibility in the region harboring both heme ligands, which could provide a possible increased affinity of CBS p.P49L for CO.

Because the major cellular $\mathrm{H}_{2} \mathrm{~S}$-producing enzymes utilize PLP as a cofactor, the nutritional status of vitamin $\mathrm{B} 6$ may influence $\mathrm{H}_{2} \mathrm{~S}$ production in humans. DeRatt et al. investigated this relationship using the gas chromatography method with a sulfur chemiluminescence detector and performed a quantitative analysis of surrogate markers of $\mathrm{H}_{2} \mathrm{~S}$ production lanthionine and homolanthionine [194]. Healthy adults undertook a 28 day dietary vitamin B6 restriction and plasma concentrations of lanthionine and homolanthionine were measured at different time points. DeRatt et al. reported no significant effect of vitamin B6 restriction on mean lanthionine and homolanthionine concentrations [194]. The precursor-product relation between cysteine and lanthionine was preserved before and after vitamin $\mathrm{B} 6$ restriction, which suggested that lanthionine production by CBS was not affected by short-term vitamin B6 insufficiency. In contrast, the precursor-product relation of Hcy and homolanthionine was diminished after vitamin B6 restriction, likely because of the reduction in CSE activity caused by vitamin B6 insufficiency. These findings suggest that homolanthionine production could be associated with vitamin B6 status in humans, although a moderate short-term deficiency did not change plasma homolanthionine concentrations significantly [194].

While transsulfuration reactions are intracellular, CBS activity has been detected in human plasma [186], and CBS and D-amino acid oxidase protein were detected in human cerebrospinal fluid by Western blot [195]. The finding of plasmatic CBS enzymatic activity has been proposed as a tool for the diagnosis of patients with classic homocystinuria [186]. The assay employs only $20 \mu \mathrm{L}$ of plasma and utilizes isotopically labeled serine $(2,3,3-$ ${ }^{2} \mathrm{H}$ serine) as substrate to produce the corresponding isotopically labeled cystathionine $\left(3,3-{ }^{2} \mathrm{H}\right.$-cystathionine) as product. Formation of $3,3-{ }^{2} \mathrm{H}$-cystathionine was monitored by LC-MS/MS, and was proven to discriminate clearly between healthy controls and patients with CBS deficiency [186].

The $S Q Q R$ enzyme is part of the $\mathrm{H}_{2} \mathrm{~S}$ catabolic pathway and mutations in this enzyme might be a new genetic cause of Leigh's disease [66,131]. Friederich et al. determined $\mathrm{H}_{2} \mathrm{~S}$ concentrations in patients with mutations in SQQR [131]. SQQR is located in the inner mitochondrial membrane and it oxidizes $\mathrm{H}_{2} \mathrm{~S}$ in the first catabolic step (see Figure 7). The study examined the homozygous c.637G > A and c.446delT mutation in different groups of patients. For $\mathrm{H}_{2} \mathrm{~S}$ determination, Friedrich et al. used the UV-spectrophotometry method [196]. Functional assays showed impaired SQOR enzyme activity due to protein instability as well as isolated decreased complex IV activity, but normal complex IV protein concentration and complex formation. These enzyme variants limited $\mathrm{H}_{2} \mathrm{~S}$ metabolization and resulted in episodic hydrogen sulfide accumulation (concentrations not shown) and complex IV inhibition (activity in liver: $0.4 \mathrm{nmol} \mathrm{\textrm {min } ^ { - 1 } \mathrm { mg } \text { protein }}{ }^{-1}$ vs. control: $1.8 \mathrm{nmol} \mathrm{min}^{-1} \mathrm{mg}_{\text {protein }}{ }^{-1}$ ). Elevated concentration of $\mathrm{H}_{2} \mathrm{~S}$ inhibits the respiratory chain by coordination of $\mathrm{H}_{2} \mathrm{~S}$ to the iron in the heme group of complex IV.

Kabil and Banerjee reported on two different mutations in persulfide dioxygenase (ETHE1), which causes ethylmalonic encephalopathy in humans [197]. This enzyme converts persulfides into sulfite in the mitochondrial sulfide oxidation pathway. The study examined the kinetic activity of human recombinant ETHE1 variants T152I and D196N. ETHE1 was described as an oxygen-dependent enzyme, which suggests possible $\mathrm{H}_{2} \mathrm{~S}$ accumulation under hypoxic conditions. The study determined thiosulfate and $\mathrm{H}_{2} \mathrm{~S}$ concentration via MBB, followed by HPLC and mass spectrometry. Both mutations resulted in a several-fold lower enzyme activity and an accumulation of hydrogen sulfide. Activity findings and concentrations of $\mathrm{H}_{2} \mathrm{~S}$ are found in this study.

Inborn errors affecting ETHE1 were also examined by Tiranti et al. [197]. This study investigated $\mathrm{H}_{2} \mathrm{~S}$ concentration in plasma and urine of patients with diagnosed ethylmalonic encephalopathy, as well as the phenotype of an animal model of ETHE1 deficiency. The 
concentration of $\mathrm{H}_{2} \mathrm{~S}$ in the samples was determined with the zinc acetate trap method, followed by gas chromatography with a sulfur chemiluminescence detector. The experimental results showed several-fold higher urinary thiosulfate concentration $(18 \mathrm{nmol}$ per

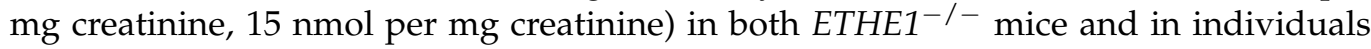
carrying mutations in the ETHE1 gene compared to their corresponding healthy control groups ( $2 \mathrm{nmol}$ per $\mathrm{mg}$ creatinine $/ 1 \mathrm{nmol}$ per $\mathrm{mg}$ creatinine). These results suggested an increased endogenous production of thiosulfate, which reflects the presence of hydrogen sulfide. In addition, the group identified low cyclooxygenase (COX) activity in muscle and brain, which was attributed to the toxic accumulation of $\mathrm{H}_{2} \mathrm{~S}$. In contrast, they reported normal COX activity and abundance in $E T H E 1^{-/-}$liver, despite high $\mathrm{H}_{2} \mathrm{~S}$ concentrations. This observation may reflect the presence of organ-specific alternative metabolic pathways for $\mathrm{H}_{2} \mathrm{~S}$ detoxification. Ditrói et al. later recapitulated the findings of Tiranti et al., by means of an optimized monobromobimane method [27,197].

\section{2. $\mathrm{H}_{2} \mathrm{~S}$ Metabolism in Animal Models of Human Disease}

\subsubsection{Cystathione $\beta$-Synthase (CBS)}

Mice carrying homozygous mutations in the CBS gene do not thrive beyond the first 3 weeks of life [198]. Results from a recent study indicate that lethality in CBS knockout mice is brought about by abnormal buildup of methionine in the liver. Accumulation of Met in the liver was accompanied by downstream disturbances in central pathways of energy metabolism [199]. Strikingly, neither a methionine restricted diet nor cystathionine injections could rescue lethality in CBS-null mice [199]. A CBS heterozygous knockout $\left(\mathrm{CBS}^{+/-}\right)$mouse model was developed by Jensen et al. and the formation of $\mathrm{H}_{2} \mathrm{~S}$ in $\mathrm{CBS}^{+/-}$ and wild type animals was measured [200]. They chose the methylene blue method in combination with HPLC and described significantly reduced $\mathrm{H}_{2} \mathrm{~S}$ concentration by $30-46 \%$ compared to wild type in male and female animals (exact concentrations not shown). In a second experiment, the group overexpressed CBS in mouse liver by adenoviral delivery of the human CBS (hCBS) transgene. As a result, the treatment with hCBS adenovirus increased CBS activity by 1.4 -fold and the $\mathrm{H}_{2} \mathrm{~S}$ concentration in plasma increased by 1.8 -fold $(50 \mu \mathrm{M}$ versus $90 \mu \mathrm{M})$ [200]. Moreover, Hcy concentration in plasma was significantly reduced. In a third experimental setting, Jensen et al. supplemented mice with ethionine, a methionine analog that activates CBS in the same way as SAM [200]. The results were similar to those described before. In $\mathrm{CBS}^{+/-}$and wild type mice supplemented with ethionine, $\mathrm{CBS}$ activity as well as the circulating $\mathrm{H}_{2} \mathrm{~S}$ concentration were increased, while Hcy concentration was reduced with respect to mice without supplementation.

An independent study investigated the phenotype of a heterozygous $\mathrm{CBS}^{+/-}$mouse model [201]. This work assessed CBS enzyme activity and the effect of the long-acting $\mathrm{H}_{2} \mathrm{~S}$ donor GYY4137 in wild type under homocystinuric conditions. The synthetic $\mathrm{H}_{2} \mathrm{~S}$ donor GYY4137 (crystalline solid in nature) was dissolved in phosphate buffered saline (PBS) and injected intraperitoneally to mice, while the control mice were given normal saline for 6 weeks. The expression of CBS, CSE and MTHFR was decreased in the retina of mice with genotype $\mathrm{CBS}^{+/-}$, a result that was reversed upon addition of the $\mathrm{H}_{2} \mathrm{~S}$ donor GYY4137 [201]. Treatment of the animals with GYY4137 reduced the concentrations of markers of oxidative stress, which suggests that $\mathrm{H}_{2} \mathrm{~S}$ could play an important role in maintaining an antioxidant environment. Additional findings of their experimental work were reduced glutamate concentrations, baseline levels of the ocular pressure, improvement in blood-retinal barrier and visual guided behavioral functions after injection of GYY4137.

Another study employed a homozygous CBS knockout mouse model within their viable lifetime ( $\mathrm{CBS}^{-/-}$, days $\left.18-19\right)$ and compared $\mathrm{H}_{2} \mathrm{~S}$ production in knockout and wild type animals [202]. Due to the total CBS knockout in the model, the relative contribution of $\mathrm{CBS}$ to the overall $\mathrm{H}_{2} \mathrm{~S}$ production could be measured precisely. This study examined metabolites of the transsulfuration pathway, including cysteine and lanthionine, using MBB derivatization and LC-MS/MS. The results showed decreased $\mathrm{H}_{2} \mathrm{~S}$ production down to $25 \%$ in the knockout liver extract compared to the WT liver tissue $(0.2 \mathrm{U} / \mathrm{mg}$ of protein 
$\mathrm{WT}, 0.7 \mathrm{U} / \mathrm{mg}$ of protein $\mathrm{KO}$ ). Findings from this study suggested that the majority of $\mathrm{H}_{2} \mathrm{~S}$ formation in the liver is due to CBS and approximately $25 \%$ is maintained by CSE and possibly 3MST [202].

\subsubsection{Cystathione $\gamma$-Lyase (CSE)}

Leigh et al. developed a murine model of CSE deficiency in order to elucidate the effect of $\mathrm{H}_{2} \mathrm{~S}$ on in vivo renal erythropoietin (EPO) production [203]. They created a homozygous $\mathrm{CSE}^{-/-}$knockout mice and compared them to wild type under different experimental conditions. First, the mice were subjected to either a $72 \mathrm{~h}$ period of hypoxia $\left(11 \% \mathrm{O}_{2}\right)$ or normoxia $\left(21 \% \mathrm{O}_{2}\right)$. During this period, the mice received two injections of either saline or the $\mathrm{H}_{2} \mathrm{~S}$-releasing molecule $\mathrm{Na}_{2} \mathrm{~S}$. Hypoxic wild type mice showed an increase in hemoglobin concentration (from $120 \mathrm{~g} / \mathrm{L}$ to $180 \mathrm{~g} / \mathrm{L}$ ), in contrast to the hypoxic knockout mice. Similar hydrogen sulfide concentration was measured in hypoxic and normoxic mice after injections of either saline or $\mathrm{Na}_{2} \mathrm{~S}$. When comparing $\mathrm{H}_{2} \mathrm{~S}$ concentrations of hypoxic and normoxic mice from the same mouse strain, no significant difference could be detected (0.15 nM WT normoxia, $0.16 \mathrm{nM}$ WT hypoxia, $0.05 \mathrm{nM} \mathrm{CSE}^{-/-}$normoxia, $0.06 \mathrm{nM} \mathrm{CSE}^{-/-}$ hypoxia). The injection of $\mathrm{Na}_{2} \mathrm{~S}$ given to $\mathrm{CSE}^{-/-}$mice in hypoxia significantly rescued hemoglobin concentrations and increased the concentration of circulating $\mathrm{H}_{2} \mathrm{~S}$ [203]. On the other hand, under normoxic conditions, wild type mice exhibited significantly higher whole blood $\mathrm{H}_{2} \mathrm{~S}$ concentration compared to $\mathrm{CSE}^{-/-}$mice $\left(0.15 \mathrm{nM} \mathrm{WT}, 0.05 \mathrm{nM} \mathrm{CSE}^{-/-}\right)$. Normoxic $\mathrm{CSE}^{-/-}$mice exhibited significantly higher EPO protein signal intensity than normoxic wild type mice (1.14 $\left.\mathrm{CSE}^{-/-}, 0.06 \mathrm{WT}\right)$. During hypoxic conditions, this trend was reversed, and wild type mice exhibited a significantly higher signal intensity of EPO protein than their $\mathrm{CSE}^{-/-}$counterparts $\left(0.3 \mathrm{CSE}^{-/-}, 0.9 \mathrm{WT}\right)$. In sum, $\mathrm{H}_{2} \mathrm{~S}$ supplementation had a significant positive impact on EPO production during hypoxia but not during normoxia. In this way, Leigh et al. presented experimental evidence supporting the postulate that $\mathrm{H}_{2} \mathrm{~S}$ regulates EPO production through the HIF-pathway [203]. $\mathrm{H}_{2} \mathrm{~S}$ could therefore operate as an oxygen sensor during erythropoiesis.

In addition to the above described homozygous mouse model of CSE deficiency, Yang et al. generated heterozygous $\mathrm{CSE}^{+/-}$and homozygous $\mathrm{CSE}^{-/-}$mutant mice in order to investigate the role of $\mathrm{H}_{2} \mathrm{~S}$ as a vasorelaxant and its impact on blood pressure [96]. An ionselective electrode was used for determination of $\mathrm{H}_{2} \mathrm{~S}$ concentrations. The concentration of $\mathrm{H}_{2} \mathrm{~S}$ in aorta and heart tissue was reduced around $80 \%$ in $\mathrm{CSE}^{-/-}$and around $50 \%$ in $\mathrm{CSE}^{+/-}$mice. In serum, the $\mathrm{H}_{2} \mathrm{~S}$ concentration was reduced around $50 \%$ in $\mathrm{CSE}^{-/-}$and $20 \%$ in $\mathrm{CSE}^{+/-}$mice [96]. Especially in the vascular system, CSE was reported as the main contributor to $\mathrm{H}_{2} \mathrm{~S}$ formation [96]. The study revealed that mice devoid of CSE developed age-dependent hypertension, thereby providing evidence that $\mathrm{H}_{2} \mathrm{~S}$ could be a regulator of blood pressure.

\subsubsection{Cysteine Dioxygenase}

The homeostasis of $\mathrm{H}_{2} \mathrm{~S}$ was also investigated in a mouse model of cysteine dioxygenase (CDO) deficiency, an enzyme that has a major role in the catabolic pathway of cysteine [204]. $\mathrm{CDO}$ catalyzes the dioxygenation of cysteine to cysteine sulfinate in mammals. Cysteine can also undergo the previously described desulfhydration reaction, which is mainly catalyzed by the transsulfuration enzymes producing $\mathrm{H}_{2} \mathrm{~S}$ as a side product. Indirect $\mathrm{H}_{2} \mathrm{~S}$ markers such as thiosulfate, COX inhibition, hypotaurine and taurine were determined in CDO-deficient animals. Due to the complete lack of CDO activity, nearly all of the cysteine was metabolized by the transsulfuration enzymes, which resulted in several-fold elevated indirect $\mathrm{H}_{2} \mathrm{~S}$ markers (e.g., thiosulfate: $420 \mu \mathrm{M} / \mathrm{mg}$ creatinine female $\mathrm{KO}, 320 \mu \mathrm{M} / \mathrm{mg}$ creatinine male $\mathrm{KO}, 100 \mu \mathrm{M} / \mathrm{mg}$ creatinine WT) [204].

\subsubsection{Rhodanese}

Rhodanese is another component of $\mathrm{H}_{2} \mathrm{~S}$ catabolism, which catalyzes the transfer of sulfane sulfur from glutathione persulfide (GSSH) to sulfite-generating thiosulfate, 
and from thiosulfate to cyanide-generating thiocyanate [134]. Rhodanese is abundant in kidney, liver and colon and it plays an important role in maintaining constant $\mathrm{H}_{2} \mathrm{~S}$ concentration. Libiad et al. analyzed the specific polymorphic variants of rhodanese E102D and P285A expressed in murine liver concerning protein stability and kinetic activity [134]. The formation of $\mathrm{H}_{2} \mathrm{~S}$ was measured in a turbidometric lead acetate assay followed by UV-spectrophotometry. Thiosulfate was quantified with the monobromobimane method and LC-MS/MS. For determination of thiosulfate-dependent $\mathrm{H}_{2} \mathrm{~S}$ generation the authors used gas chromatography. Libiad et al. observed a more stable protein structure in the polymorphic variants compared to wild type [134]. The specific activity was several-fold higher in both variants (4- and 2.7-fold higher specific activities, thiosulfate-dependent $\mathrm{H}_{2} \mathrm{~S}$ production: $1.2 \mu \mathrm{mol} \mathrm{min}^{-1} \mathrm{~g}$ tissue ${ }^{-1}$ ) [134].

Table 4. Determination of hydrogen sulfide production in genetic diseases of metabolism.

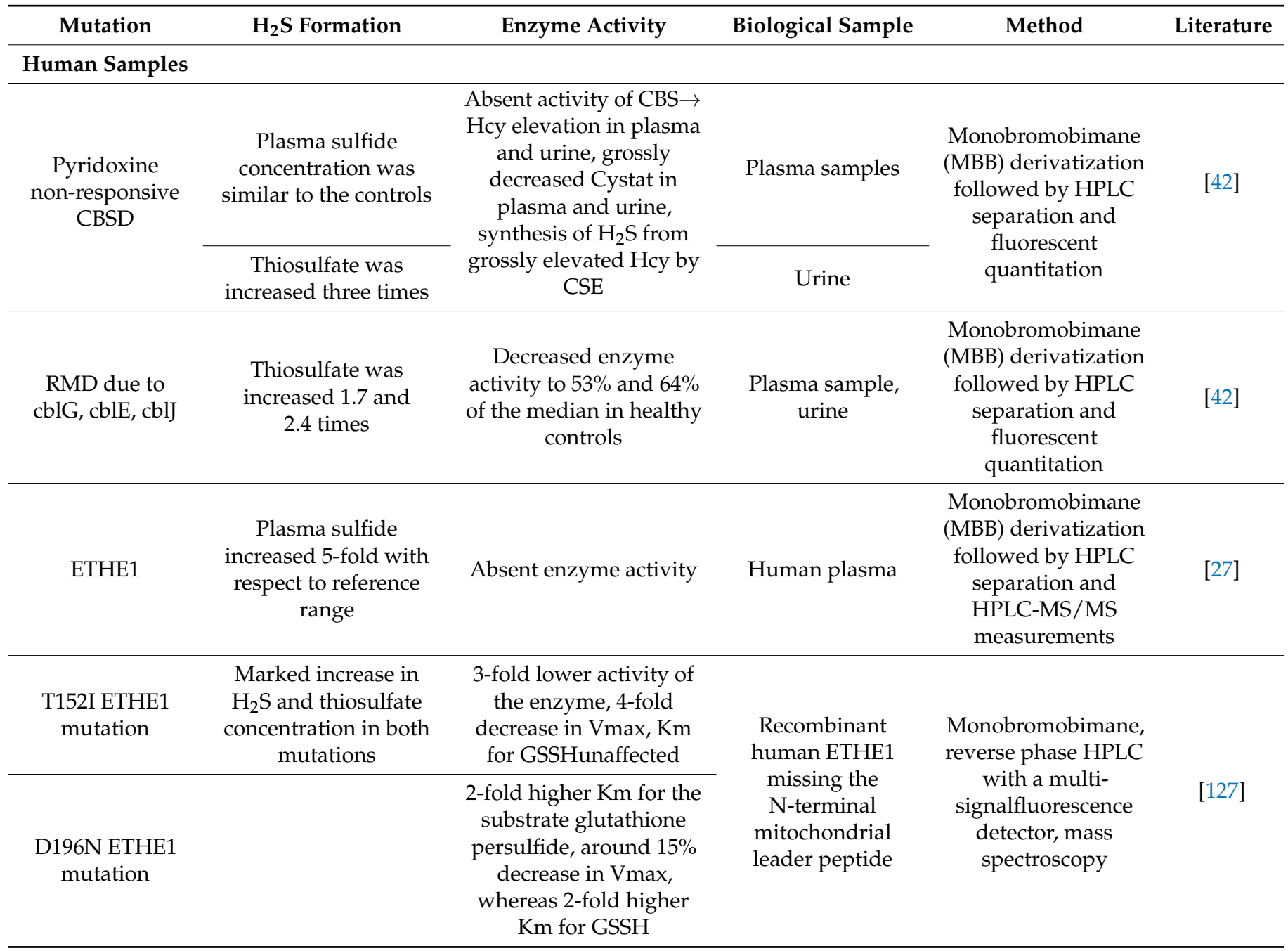


Table 4. Cont.

\begin{tabular}{|c|c|c|c|c|c|}
\hline Mutation & $\mathrm{H}_{2} \mathrm{~S}$ Formation & Enzyme Activity & Biological Sample & Method & Literature \\
\hline ETHE1 $^{-/-}$ & $\begin{array}{l}\mathrm{H}_{2} \mathrm{~S} \text { concentration in } \\
\text { all tissues much higher } \\
\text { compared to WT: } \\
\text { brain: } 5 \text {-fold higher, } \\
\text { muscle: } 10 \text {-fold higher, } \\
\text { liver: } 10 \text {-fold } \\
\text { higherthiosulfate in } \\
\text { urine several-fold } \\
\text { higher, sulfate lower, } \\
\text { thiosulfate markedly } \\
\text { increased in kidney, } \\
\text { liver, muscle and brain }\end{array}$ & $\begin{array}{c}\text { Total lack of ETHE1 } \\
\text { activity }\end{array}$ & $\begin{array}{l}\text { Ethe }^{-/-} \text {mice: } \\
\text { liver, brain, kidney, } \\
\text { external muscle, } \\
\text { layers of colon, } \\
\text { urine } \\
\text { human (with } \\
\text { ethylmalonic } \\
\text { encephalopathy) } \\
\text { blood and urine }\end{array}$ & $\begin{array}{l}\text { Zinc acetate trap, gas } \\
\text { chromatogra- } \\
\text { phy/sulfur } \\
\text { chemiluminescence } \\
\text { detector }\end{array}$ & {$[197,205]$} \\
\hline CBS p.P49L & $\begin{array}{c}\text { 3-fold lower } \mathrm{H}_{2} \mathrm{~S} \\
\text { formation in } \\
\text { PLP-untreated CBS, } \\
\text { similar formation by } \\
\text { SAM stimulation } \\
\mathrm{H}_{2} \mathrm{~S} \text { formation similar } \\
\text { to } \mathrm{WT} \text { in PLP-treated } \\
\mathrm{CBS} \text {, impaired } \\
\text { formation by SAM } \\
\text { stimulation (1.1-fold } \\
\text { vs. } 1.9 \text {-fold in } \mathrm{WT}) \mathrm{CO} \\
\text { inhibits the } \mathrm{H}_{2} \mathrm{~S} \\
\text { producing activity }\end{array}$ & $\begin{array}{c}\text { Structural changes affect } \\
\text { heme reactivity, } \\
\text { enhanced affinity for } \\
\text { CO, poor responsiveness } \\
\text { to SAM }\end{array}$ & $\begin{array}{l}\text { Human cultured } \\
\text { fibroblasts }\end{array}$ & $\begin{array}{l}\text { Amperometry with } \\
\mathrm{H}_{2} \mathrm{~S} \text {-selective elec- } \\
\text { trode/coulometry } \\
\text { (acetate method), } \\
\text { UV- } \\
\text { spectrophotometry }\end{array}$ & {$[193,206]$} \\
\hline $\begin{array}{l}\text { Vitamin B6 } \\
\text { insufficiency }\end{array}$ & $\begin{array}{l}\text { Impaired } \mathrm{H}_{2} \mathrm{~S} \\
\text { production capacity } \\
\text { because of the } \\
\text { sensitivity of CSE to } \\
\text { inactivation by loss of } \\
\text { the PLP coenzyme }\end{array}$ & $\begin{array}{l}\text { Little or no effect on CBS } \\
\text { activity in the presence } \\
\text { or absence of } \\
\text { stimulation by SAM, } \\
\text { CSE exhibited } 70 \% \\
\text { lower activity, lower } \\
\text { production of } \\
\mathrm{H}_{2} \text { S-specific biomarkers }\end{array}$ & $\begin{array}{c}\text { Human lysates of } \\
\text { cultured hepatoma } \\
\text { cells }\end{array}$ & $\begin{array}{c}\text { Gas chromatography } \\
\text { with sulfur } \\
\text { chemiluminescence } \\
\text { detector }\end{array}$ & [194] \\
\hline $\begin{array}{c}\text { c.637G > A, a } \\
\text { Glu213Lys } \\
\text { variant of } \\
\text { SQORc.446delT }\end{array}$ & $\begin{array}{l}\text { Episodic accumulation } \\
\text { of } \mathrm{H}_{2} \mathrm{~S} \text {, at high } \\
\text { concentrations } \mathrm{H}_{2} \mathrm{~S} \text { can } \\
\text { coordinate to the iron } \\
\text { in the heme a group of } \\
\text { complex IV resulting } \\
\text { in strong inhibition }\end{array}$ & $\begin{array}{l}\text { Compared to WT, } \\
\text { mutants exhibited: } \\
\text { reduced SQOR protein } \\
\text { and enzyme activity, } \\
\text { unchanged sulfide } \\
\text { generating enzyme } \\
\text { concentration, reduced } \\
\text { fibroblast SQOR enzyme } \\
\text { activity and protein } \\
\text { concentration, reduced } \\
\text { SQOR protein and } \\
\text { enzyme activity, } \\
\text { unchanged sulfide } \\
\text { generating enzyme } \\
\text { concentration, decreased } \\
\text { complex IV activity, but } \\
\text { normal complex IV } \\
\text { protein concentration } \\
\text { and complex formation }\end{array}$ & $\begin{array}{c}\text { Isolated } \\
\text { mitochondrial } \\
\text { membrane } \\
\text { fractions from } \\
\text { human liver, } \\
\text { lysates derived } \\
\text { from peripheral } \\
\text { blood } \\
\text { mononuclear cells } \\
\text { and from } \\
\text { fibroblasts }\end{array}$ & $\begin{array}{l}\text { UV- } \\
\text { spectrophotometry, } \\
\text { monitoring of the } \\
\text { decrease in } \\
\text { absorbance at } \\
278 \text { nm due to } \\
\text { reduction of CoQ1 }\end{array}$ & {$[131,195]$} \\
\hline
\end{tabular}


Table 4. Cont.

\begin{tabular}{|c|c|c|c|c|c|}
\hline Mutation & $\mathrm{H}_{2} \mathrm{~S}$ Formation & Enzyme Activity & Biological Sample & Method & Literature \\
\hline \multicolumn{6}{|l|}{ Animal models } \\
\hline $\begin{array}{l}\text { Cysteine } \\
\text { dioxygenase } \\
\text { knockout } \\
\mathrm{CDO}^{-/-}\end{array}$ & $\begin{array}{l}\text { 4.5-fold elevated } \\
\text { concentration of } \\
\text { urinary thiosulfate, } \\
\text { lower abundances of } \\
\text { COX4 and COX5b in } \\
\text { liver, pancreas and } \\
\text { kidney, slight } \\
\text { elevation in plasma } \\
\text { sulfate concentration, } \\
\text { excess } \mathrm{H}_{2} \mathrm{~S} / \mathrm{HS}^{-} \\
\text {production }\end{array}$ & $\begin{array}{l}\text { Complete lack of CDO } \\
\text { activity }\end{array}$ & $\begin{array}{l}\text { Mouse liver, } \\
\text { kidney, brain, } \\
\text { pancreas }\end{array}$ & $\begin{array}{c}\text { Indirect } \\
\text { measurement of } \mathrm{H}_{2} \mathrm{~S} \\
\text { (i.e., thiosulfate } \\
\text { excretion, } \\
\text { cytochrome c } \\
\text { oxidase (COX) } \\
\text { inhibition): taurine } \\
\text { and hypotaurine } \\
\text { were measured by } \\
\text { HPLC, COX4 and } \\
\text { COX5 by Western } \\
\text { blotting }\end{array}$ & [204] \\
\hline $\begin{array}{l}\text { Homozygous } \\
\left(\mathrm{CSE}^{-/-}\right) \text {and } \\
\text { heterozygous } \\
\left(\mathrm{CSE}^{-/+}\right) \text {mutant } \\
\text { mice }\end{array}$ & $\begin{array}{l}\text { Homozygous mice } \\
\text { compared to WT } \\
\text { exhibited: endogenous } \\
\mathrm{H}_{2} \mathrm{~S} \text { concentration in } \\
\text { aorta and heart } \\
\text { decreased by about } \\
80 \% \text {, serum } \mathrm{H}_{2} \mathrm{~S} \\
\text { concentration by about } \\
50 \% \text { Heterozygous } \\
\text { mice compared to WT } \\
\text { exhibited: } \mathrm{H}_{2} \mathrm{~S} \\
\text { concentration in aorta } \\
\text { and heart decreased by } \\
\text { about } 50 \%, \text { serum } \mathrm{H}_{2} \mathrm{~S} \\
\text { concentration } \\
\text { decreased by about } \\
20 \%\end{array}$ & $\begin{array}{c}\mathrm{CBS}^{-/-} \text {: Complete lack } \\
\text { of enzyme } \\
\text { activityCSE } \\
50 \% \text { lower CBS activity } \\
\text { versus wild type }\end{array}$ & $\begin{array}{l}\text { Mouse heart, aorta, } \\
\text { vascular system, }\end{array}$ & $\begin{array}{c}\text { Ion-selective } \\
\text { electrode on a Fisher } \\
\text { Accumet Model } 10 \\
\text { pH meter }\end{array}$ & [96] \\
\hline $\begin{array}{c}\text { CBS } \\
\text { heterozygous } \\
\text { knockout } \\
\left(\mathrm{CBS}^{-/+}\right) \text {mice }\end{array}$ & $\begin{array}{c}\text { Significantly reduced } \\
\mathrm{H}_{2} \mathrm{~S} \text { concentration by } \\
30 \% \text { and } 46 \% \\
\text { compared to wild type } \\
\text { in male and female } \\
\mathrm{CBS}^{-/+}\end{array}$ & $\begin{array}{c}\text { Around } 50 \% \text { CBS } \\
\text { activity compared to WT }\end{array}$ & Mouse liver & $\begin{array}{l}\text { Methylene blue } \\
\text { method, HPLC and } \\
\text { quantification by }\end{array}$ & [200] \\
\hline $\begin{array}{l}\text { CBS treated with } \\
\text { the Ad-lacZ } \\
\text { virus (Ad-hCBS) }\end{array}$ & $\begin{array}{c}\text { Increased } \mathrm{H}_{2} \mathrm{~S} \\
\text { concentration in } \\
\text { plasma by } 1.8 \text {-fold }\end{array}$ & $\begin{array}{l}\text { Increased CBS activity } \\
\text { by } 1.4 \text {-fold, reduced } \\
\text { homocysteine } \\
\text { concentration } \\
\text { significantly by } 5.3 \text {-fold }\end{array}$ & & $\begin{array}{l}\text { fluorescence detector } \\
\text { (measurement of } \\
\text { thiol metabolites) }\end{array}$ & \\
\hline
\end{tabular}


Table 4. Cont.

\begin{tabular}{|c|c|c|c|c|c|}
\hline Mutation & $\mathrm{H}_{2} \mathrm{~S}$ Formation & Enzyme Activity & Biological Sample & Method & Literature \\
\hline $\begin{array}{l}\text { E102D variant of } \\
\text { rhodanese } \\
\text { P285 A variant of } \\
\text { rhodanese }\end{array}$ & $\begin{array}{l}\mathrm{H}_{2} \mathrm{~S} \text { production in } \\
\text { murine liver lysate is } \\
\text { low }\end{array}$ & $\begin{array}{l}\text { More stable than wild } \\
\text { type, exhibition of 4- } \\
\text { and 2.7-fold higher } \\
\text { specific activity, lower } \\
\text { Kmfor cyanide for the } \\
\text { E102D, but higher for } \\
\text { the P285A, higher Km } \\
\text { for thiosulfate for E102D, } \\
\text { but lower for P285A, 17- } \\
\text { and 1.6-fold higher } \\
\text { catalytic efficiency } \\
\text { (kcat/Km(CN)) in the } \\
\text { cyanide detoxification } \\
\text { assay, } 1.6 \text { and } 4 \text {-fold } \\
\text { lower sulfur transfer } \\
\text { reaction from GSSH to } \\
\text { sulfite, similar kcat/Km } \\
\text { GSSH values }\end{array}$ & $\begin{array}{l}\text { Murine liver, } \\
\text { human blood (wild } \\
\text { type human } \\
\text { rhodanese and } \\
\text { recombinant } \\
\text { variants) }\end{array}$ & $\begin{array}{l}\text { Turbidimetric lead } \\
\text { acetate assay, UV- } \\
\text { spectrophotometry, } \\
\text { monobromobimane, } \\
\text { reverse phase HPLC } \\
\text { column, MS } \\
\text { (detection of } \\
\text { thiosulfate) } \\
\text { thiosulfate- } \\
\text { dependent } \mathrm{H}_{2} \mathrm{~S} \\
\text { generation: gas } \\
\text { chromatography }\end{array}$ & [134] \\
\hline $\begin{array}{l}\mathrm{CSE}^{-/-} \text {mice on } \\
\text { a C57BL/6 } \\
\text { background (in } \\
\text { hypoxia for a } \\
72 \mathrm{~h} \\
\text { period)injection } \\
\text { of either saline }\end{array}$ & $\begin{array}{c}\text { Reduced } \mathrm{H}_{2} \mathrm{~S} \\
\text { concentration in } \\
\text { mutant compared to } \\
\text { WT }\end{array}$ & $\begin{array}{l}\text { Lower hemoglobin } \\
\text { concentration, higher } \\
\text { EPO concentration than } \\
\text { wild type mice during } \\
\text { normoxia, but lower } \\
\text { during hypoxia, hypoxia } \\
\text { downregulates CBS } \\
\text { expression }\end{array}$ & \multirow{2}{*}{$\begin{array}{l}\text { Mouse blood, } \\
\text { kidney, human } \\
\text { urine }\end{array}$} & \multirow{2}{*}{$\begin{array}{l}\text { sulfide } / \mathrm{H}_{2} \mathrm{~S} \\
\text {-sensitive } \\
\text { microelectrode } \\
\text { system (ion } \\
\text { electrode)HPLC } \\
\text { (thiosulfate } \\
\text { concentration) }\end{array}$} & \multirow[t]{2}{*}{ [203] } \\
\hline or $\mathrm{Na}_{2} \mathrm{~S}$ & $\begin{array}{l}\text { Comparable blood } \\
\mathrm{H}_{2} \mathrm{~S} \text { concentration in } \\
\text { mutants and wild type }\end{array}$ & $\begin{array}{l}\text { Rescue of hemoglobin } \\
\text { concentration, rescued } \\
\text { EPO concentration } \\
\text { during hypoxia, } \\
\text { increased CBS protein } \\
\text { concentration in hypoxic } \\
\text { CSE }^{-/-}\end{array}$ & & & \\
\hline $\begin{array}{c}\mathrm{CBS}^{+/-} \\
(\mathrm{B} 6.129 \mathrm{P} 2- \\
\text { CBStm1Unc/J } \\
\text { 002853) }\end{array}$ & $\begin{array}{c}\mathrm{H}_{2} \mathrm{~S} \text { added } \\
\text { exogenously via } \\
\text { GYY4137, a slow } \mathrm{H}_{2} \mathrm{~S} \\
\text { donor }\end{array}$ & $\begin{array}{l}\text { Decreased CBS, CSE and } \\
\text { MTHFR expressions, } \\
\text { GYY4137 treatment } \\
\text { rescues their } \\
\text { concentration, GYY4137 } \\
\text { reduces oxidative stress } \\
\text { marker concentration } \\
\text { and total GSH } \\
\text { concentration, it } \\
\text { normalizes overall } \\
\text { glutamate concentration, } \\
\text { it reduces ocular } \\
\text { pressure back to the } \\
\text { baseline levels and } \\
\text { enables less vessel } \\
\text { density and } \\
\text { permeability in the eye }\end{array}$ & $\begin{array}{l}\text { Mouse blood, } \\
\text { retinal tissue }\end{array}$ & $\begin{array}{l}\text { GYY4137 (crystalline } \\
\text { solid in nature) } \\
\text { dissolved in } \\
\text { phosphate buffered } \\
\text { saline (PBS) and } \\
\text { injected } \\
\text { intraperitoneally to } \\
\text { mice }\end{array}$ & [201] \\
\hline $\begin{array}{l}\text { CBS-knockout } \\
(\mathrm{KO}) \text { mice }\end{array}$ & $\begin{array}{l}\sim 25 \% \text { of } \mathrm{H}_{2} \mathrm{~S} \text {-forming } \\
\text { activity when no } \\
\text { activity in presence of } \\
\text { CSE inhibitor PAG }\end{array}$ & Total lack of CBS activity & $\begin{array}{l}\text { Mouse liver, } \\
\text { kidney, } \\
\text { brainMonkey } \\
\text { plasma (WT) }\end{array}$ & LC-MS/MS, HPLC & [202] \\
\hline
\end{tabular}




\section{Current Limitations and Future Studies}

Hydrogen sulfide is a gasotransmitter with high volatility and a very short half-life due to its reactivity with low- and high-molecular weight biological targets. The chemical nature of $\mathrm{H}_{2} \mathrm{~S}$ makes it difficult to determine its real concentration in biofluids, cells and tissues. Both in vitro and in vivo studies suggest that $\mathrm{H}_{2} \mathrm{~S}$ concentrations vary quickly in response to stimuli, which demands a continuous, real-time measurement. Different methods for the determination of $\mathrm{H}_{2} \mathrm{~S}$ exhibit widely different detection limits and sensitivities, partly due to interfering substances, which poses a challenge to its accurate quantitation. Aside from this caveat, not all methods capture all major species of $\mathrm{H}_{2} \mathrm{~S}$, that is, $\mathrm{H}_{2} \mathrm{~S} / \mathrm{HS}^{-}$. The absolute concentrations of $\mathrm{H}_{2} \mathrm{~S}$ measured in different studies with different methods cannot therefore be compared side-by-side. Currently, monobromobimane derivatization is seen as the gold standard method, despite the previously mentioned disadvantages and the complicated sample pre-analytics required for quantification. Nevertheless, the summary presented in Table 3 enables a quick overview of currently available methods, which should assist investigators in deciding which setting fits best for their own research question. A yet to be developed method for the specific, reproducible, simple, sensitive and affordable determination of $\mathrm{H}_{2} \mathrm{~S}$ in real time would sort out many of the currently unexplained variations in $\mathrm{H}_{2} \mathrm{~S}$ steady-state concentrations and access the rate of $\mathrm{H}_{2} \mathrm{~S}$ production in biological systems. Given the short-lived nature of $\mathrm{H}_{2} \mathrm{~S}$ and its limited accumulation in specimens that are available for human research studies (plasma, urine, cells), methods for the direct, time-resolved measurement of $\mathrm{H}_{2} \mathrm{~S}$ production may be more informative than end-point determinations of $\mathrm{H}_{2} \mathrm{~S}$ concentration.

\section{Conclusions}

Our knowledge of the biochemistry of hydrogen sulfide, the effects of exogenous addition of $\mathrm{H}_{2} \mathrm{~S}$ and donor molecules to cultured cells, tissues and laboratory animals, as well as the development of methods for its detection, have deepened steadily over the last decades. Conversely, the importance of hydrogen sulfide biosynthesis and catabolism and its impact on physiology in vivo (patient samples, animal models of $\mathrm{H}_{2} \mathrm{~S}$ disruption) have been examined by a few research groups only. Rare monogenic metabolic diseases that affect $\mathrm{H}_{2} \mathrm{~S}$ biosynthesis and catabolism provide an excellent opportunity to investigate the roles of $\mathrm{H}_{2} \mathrm{~S}$ in physiologically relevant compartments and organs, including the gut microbiome. For example, numerous mutations in the CBS gene and in other enzymes involved in sulfur amino acid metabolism have been described, yet only a handful of studies determined $\mathrm{H}_{2} \mathrm{~S}$ concentrations in these patients. As a gasotransmitter involved in vascular dilation and cognitive functions, impairments in $\mathrm{H}_{2} \mathrm{~S}$ homeostasis could contribute to the clinical manifestations of homocystinuria, cystathioninuria and other illnesses of sulfur metabolism. Further, knowledge of the specific rates of production, compartmentalization and reactivity of $\mathrm{H}_{2} \mathrm{~S}$ that occur under different pathological conditions are essential for the design of new treatments and a better understanding of the respective diseases.

Author Contributions: Conceptualization, all authors; methodology, J.M. and L.H.; software, J.M.; validation, all authors; formal analysis, all authors; investigation, all authors; resources, all authors; data curation, J.M., I.D., S.V.M., L.H.; writing—original draft preparation, J.M.; writing-review and editing, J.M., U.S. and L.H.; visualization, J.M.; supervision, L.H.; project administration, L.H.; funding acquisition, not applicable. All authors have read and agreed to the published version of the manuscript.

Funding: This research received no external funding.

Acknowledgments: The article processing charge was funded by the Baden-Wuerttemberg Ministry of Science, Research and Art and the University of Freiburg funding programme Open Access Publishing. The authors are extremely grateful to the reviewers and the editorial team for their insightful input and careful revision of our review.

Conflicts of Interest: The authors declare no conflict of interest. 


\section{References}

1. Szabo, C. A timeline of hydrogen sulfide (H2S) research: From environmental toxin to biological mediator. Biochem. Pharmacol. 2018, 149, 5-19. [CrossRef]

2. Turell, L.; Radi, R.; Alvarez, B. The thiol pool in human plasma: The central contribution of albumin to redox processes. Free Radic. Biol. Med. 2013, 65, 244-253. [CrossRef]

3. Benchoam, D.; Cuevasanta, E.; Möller, M.N.; Alvarez, B. Hydrogen sulfide and persulfides oxidation by biologically relevant oxidizing species. Antioxidants 2019, 8, 48. [CrossRef] [PubMed]

4. Cuevasanta, E.; Möller, M.N.; Alvarez, B. Biological chemistry of hydrogen sulfide and persulfides. Arch. Biochem. Biophys. 2017, 617, 9-25. [CrossRef] [PubMed]

5. Cortese-Krott, M.M.; Fernandez, B.O.; Kelm, M.; Butler, A.R.; Feelisch, M. On the chemical biology of the nitrite/sulfide interaction. Nitric Oxide Biol. Chem. 2015, 46, 14-24. [CrossRef] [PubMed]

6. May, P.M.; Batka, D.; Hefter, G.; Königsberger, E.; Rowland, D. Goodbye to S2- in aqueous solution. Chem. Commun. 2018, 54, 1980-1983. [CrossRef]

7. Morse, J.W.; Millero, F.J.; Cornwell, J.C.; Rickard, D. The chemistry of the hydrogen sulfide and iron sulfide systems in natural waters. Earth Sci. Rev. 1987, 24, 1-42. [CrossRef]

8. Li, Q.; Lancaster, J.R. Chemical foundations of hydrogen sulfide biology. Nitric Oxide Biol. Chem. 2013, 35, 21-34. [CrossRef]

9. Polhemus, D.J.; Lefer, D.J. Emergence of hydrogen sulfide as an endogenous gaseous signaling molecule in cardiovascular disease. Circ. Res. 2014, 114, 730-737. [CrossRef]

10. Giuffrè, A.; Vicente, J.B. Hydrogen sulfide biochemistry and interplay with other gaseous mediators in mammalian physiology. Oxidative Med. Cell. Longev. 2018, 2018. [CrossRef] [PubMed]

11. Mishanina, T.V.; Libiad, M.; Banerjee, R. by hydrogen sulfide oxidation pathways. Nat. Chem. Biol. 2015, 11, 57-64. [CrossRef] [PubMed]

12. Aroca, A.; Gotor, C.; Bassham, D.C. Hydrogen Sulfide: From a Toxic Molecule to a Key Molecule of Cell Life. Antioxidants 2020, 621. [CrossRef] [PubMed]

13. Jacobsen, D.W.; Hannibal, L. Redox signaling in inherited diseases of metabolism. Curr. Opin. Physiol. 2019, 9, 48-55. [CrossRef]

14. Blachier, F.; Beaumont, M.; Kim, E. Cysteine-derived hydrogen sulfide and gut health: A matter of endogenous or bacterial origin. Curr. Opin. Clin. Nutr. Metab. Care 2019, 22, 68-75. [CrossRef] [PubMed]

15. Beard, R.S.; Bearden, S.E. Vascular complications of cystathionine $\beta$-synthase deficiency: Future directions for homocysteine-tohydrogen sulfide research. Am. J. Physiol. Heart Circ. Physiol. 2011, 300. [CrossRef] [PubMed]

16. Barton, L.L.; Ritz, N.L.; Fauque, G.D.; Lin, H.C. Sulfur Cycling and the Intestinal Microbiome. Dig. Dis. Sci. 2017, 62, 2241-2257. [CrossRef]

17. Dias-junior, C.A.; Sandrim, V.; Valeria, C. Circulating levels of hydrogen sulphide negatively correlate to nitrite levels in gestational hypertensive and preeclamptic pregnant women. Clin. Exp. Pharmacol. Physiol. 2021. [CrossRef]

18. Suzuki, K.; Sagara, M.; Aoki, C.; Tanaka, S.; Aso, Y. Clinical implication of plasma hydrogen sulfide levels in Japanese patients with type 2 diabetes. Intern. Med. 2017, 56, 17-21. [CrossRef]

19. Kuang, Q.; Xue, N.; Chen, J.; Shen, Z.; Cui, X.; Fang, Y.; Ding, X. Low Plasma Hydrogen Sulfide Is Associated with Impaired Renal Function and Cardiac Dysfunction. Am. J. Nephrol. 2018, 47, 361-371. [CrossRef]

20. Karunya, R.; Jayaprakash, K.S.; Gaikwad, R.; Sajeesh, P.; Ramshad, K.; Muraleedharan, K.M.; Dixit, M.; Thangaraj, P.R.; Sen, A.K. Rapid measurement of hydrogen sulphide in human blood plasma using a microfluidic method. Sci. Rep. 2019, 9, 1-11. [CrossRef]

21. Du, S.X.; Xiao, J.; Guan, F.; Sun, L.M.; Wu, W.S.; Tang, H.; Du, J.B.; Tang, C.S.; Jin, H.F. Predictive role of cerebrospinal fluid hydrogen sulfide in central nervous system leukemia. Chin. Med. J. 2011, 124, 3450-3454. [CrossRef] [PubMed]

22. Greco, V.; Neri, C.; Pieragostino, D.; Spalloni, A.; Persichilli, S.; Gastaldi, M.; Mercuri, N.B.; Longone, P.; Urbani, A. Investigating different forms of hydrogen sulfide in cerebrospinal fluid of various neurological disorders. Metabolites 2021, 11, 152. [CrossRef]

23. Olson, K.R. Is hydrogen sulfide a circulating "gasotransmitter" in vertebrate blood? Biochim. Biophys. Acta Bioenerg. 2009, 1787, 856-863. [CrossRef]

24. Olson, K.R.; Deleon, E.R.; Liu, F. Controversies and conundrums in hydrogen sulfide biology. Nitric Oxide Biol. Chem. 2014, 41, 11-26. [CrossRef] [PubMed]

25. Kolluru, G.K.; Shen, X.; Bir, S.C.; Kevil, C.G. Hydrogen sulfide chemical biology: Pathophysiological roles and detection. Nitric Oxide Biol. Chem. 2013, 35, 5-20. [CrossRef] [PubMed]

26. Nagy, P.; Pálinkás, Z.; Nagy, A.; Budai, B.; Tóth, I.; Vasas, A. Chemical aspects of hydrogen sulfide measurements in physiological samples. Biochim. Biophys. Acta Gen. Subj. 2014, 1840, 876-891. [CrossRef] [PubMed]

27. Ditrói, T.; Nagy, A.; Martinelli, D.; Rosta, A.; Kožich, V.; Nagy, P. Comprehensive analysis of how experimental parameters affect H 2 S measurements by the monobromobimane method. Free Radic. Biol. Med. 2019, 136, 146-158. [CrossRef] [PubMed]

28. Cuevasanta, E.; Denicola, A.; Alvarez, B.; Möller, M.N. Solubility and permeation of hydrogen sulfide in lipid membranes. PLoS ONE 2012, 7, 3-8. [CrossRef]

29. Möller, M.N.; Cuevasanta, E.; Orrico, F.; Lopez, A.C.; Thomson, L.; Denicola, A. Diffusion and transport of reactive species across cell membranes. In Advances in Experimental Medicine and Biology; Springer: New York, NY, USA, 2019; Volume 1127, pp. 3-19. 
30. Olson, K.R. A theoretical examination of hydrogen sulfide metabolism and its potential in autocrine/paracrine oxygen sensing. Respir. Physiol. Neurobiol. 2013, 186, 173-179. [CrossRef] [PubMed]

31. Jennings, M.L. Transport of H2S and HS- across the human red blood cell membrane: Rapid H2S diffusion and AE1-mediated Cl-/HS- exchange. Am. J. Physiol. Cell Physiol. 2013, 305. [CrossRef]

32. Furne, J.; Saeed, A.; Levitt, M.D. Whole tissue hydrogen sulfide concentrations are orders of magnitude lower than presently accepted values. Am. J. Physiol. Regul. Integr. Comp. Physiol. 2008, 295. [CrossRef]

33. Shen, X.; Peter, E.A.; Bir, S.; Wang, R.; Kevil, C.G. Analytical measurement of discrete hydrogen sulfide pools in biological specimens. Free Radic. Biol. Med. 2012, 52, 2276-2283. [CrossRef]

34. Levitt, M.D.; Abdel-Rehim, M.S.; Furne, J. Free and acid-labile hydrogen sulfide concentrations in mouse tissues: Anomalously high free hydrogen sulfide in aortic tissue. Antioxid. Redox Signal. 2011, 15, 373-378. [CrossRef]

35. Wintner, E.A.; Deckwerth, T.L.; Langston, W.; Bengtsson, A.; Leviten, D.; Hill, P.; Insko, M.A.; Dumpit, R.; Vandenekart, E.; Toombs, C.F.; et al. A monobromobimane-based assay to measure the pharmacokinetic profile of reactive sulphide species in blood. Br. J. Pharmacol. 2010, 160, 941-957. [CrossRef]

36. Doeller, J.E.; Isbell, T.S.; Benavides, G.; Koenitzer, J.; Patel, H.; Patel, R.P.; Lancaster, J.R.; Darley-Usmar, V.M.; Kraus, D.W. Polarographic measurement of hydrogen sulfide production and consumption by mammalian tissues. Anal. Biochem. 2005, 341, 40-51. [CrossRef]

37. Ubuka, T.; Abe, T.; Kajikawa, R.; Morino, K. Determination of hydrogen sulfide and acid-labile sulfur in animal tissues by gas chromatography and ion chromatography. J. Chromatogr. B Biomed. Sci. Appl. 2001, 757, 31-37. [CrossRef]

38. Ishigami, M.; Hiraki, K.; Umemura, K.; Ogasawara, Y.; Ishii, K.; Kimura, H. A source of hydrogen sulfide and a mechanism of its release in the brain. Antioxid. Redox Signal. 2009, 11, 205-214. [CrossRef] [PubMed]

39. Tangerman, A.; Meuwese-Arends, M.T.; Van Tongeren, J.H.M. New methods for the release of volatile sulfur compounds from human serum: Its determination by Tenax trapping and gas chromatography and its application in liver diseases. J. Lab. Clin. Med. 1985, 106, 175-182. [CrossRef] [PubMed]

40. Zaorska, E.; Konop, M.; Ostaszewski, R.; Koszelewski, D.; Ufnal, M. Salivary hydrogen sulfide measured with a new highly sensitive self-immolative coumarin-based fluorescent probe. Molecules 2018, 23, 2241. [CrossRef] [PubMed]

41. Goodwin, L.R.; Francom, D.; Dieken, F.P.; Taylor, J.D.; Warenycia, M.W.; Reiffenstein, R.J.; Dowling, G. Determination of Sulfide in Brain Tissue by Gas Dialysis/Ion Chromatography: Postmortem Studies and Two Case Reports. J. Anal. Toxicol. 1989, 13, 105-109. [CrossRef] [PubMed]

42. Kožich, V.; Ditrói, T.; Sokolová, J.; Křižzová, M.; Krijt, J.; Ješina, P.; Nagy, P. Metabolism of sulfur compounds in homocystinurias. Br. J. Pharmacol. 2019, 176, 594-606. [CrossRef]

43. Tan, B.H.; Wong, P.T.; Bian, J. Neurochemistry International Hydrogen sulfide: A novel signaling molecule in the central nervous system. Neurochem. Int. 2010, 56, 3-10. [CrossRef]

44. Attene-Ramos, M.S.; Wagner, E.D.; Plewa, M.J.; Gaskins, H.R. Evidence that hydrogen sulfide is a genotoxic agent. Mol. Cancer Res. 2006, 4, 9-14. [CrossRef]

45. Fiorucci, S.; Antonelli, E.; Distrutti, E.; Rizzo, G.; Mencarelli, A.; Orlandi, S.; Zanardo, R.; Renga, B.; Di Sante, M.; Morelli, A.; et al. Inhibition of hydrogen sulfide generation contributes to gastric injury caused by anti-inflammatory nonsteroidal drugs. Gastroenterology 2005, 129, 1210-1224. [CrossRef]

46. Kimura, Y.; Dargusch, R.; Schubert, D.; Kimura, H. Hydrogen sulfide protects HT22 neuronal cells from oxidative stress. Antioxid. Redox Signal. 2006, 8, 661-670. [CrossRef]

47. Szabo, C. Hydrogen Sulfide, an Endogenous Stimulator of Mitochondrial Function in Cancer Cells. Cells 2021, 10, 220. [CrossRef]

48. Kimura, Y.; Kimura, H. Hydrogen sulfide protects neurons from oxidative stress. FASEB J. 2004, 18, 1165-1167. [CrossRef] [PubMed]

49. Chen, C.Q.; Xin, H.; Zhu, Y.Z. Hydrogen sulfide: Third gaseous transmitter, but with great pharmacological potential. Acta Pharmacol. Sin. 2007, 28, 1709-1716. [CrossRef] [PubMed]

50. Yang, G.; Sun, X.; Wang, R. Hydrogen sulfide-induced apoptosis of human aorta smooth muscle cells via the activation of mitogen-activated protein kinases and caspase-3. FASEB J. 2004, 18, 1782-1784. [CrossRef] [PubMed]

51. Renga, B. Hydrogen sulfide generation in mammals: The molecular biology of cystathionine- $\beta$-synthase (CBS) and cystathionine$\gamma$-lyase (CSE). Inflamm. Allergy Drug Targets 2011, 10, 85-91. [CrossRef] [PubMed]

52. Whiteman, M.; Le Trionnaire, S.L.; Chopra, M.; Fox, B.; Whatmore, J. Emerging role of hydrogen sulfide in health and disease: Critical appraisal of biomarkers and pharmacological tools. Clin. Sci. 2011, 121, 459-488. [CrossRef]

53. Perry, M.M.; Hui, C.K.; Whiteman, M.; Wood, M.E.; Adcock, I.; Kirkham, P.; Michaeloudes, C.; Chung, K.F. Hydrogen sulfide inhibits proliferation and release of IL-8 from human airway smooth muscle cells. Am. J. Respir. Cell Mol. Biol. 2011, 45, 746-752. [CrossRef]

54. Yang, W.; Yang, G.; Jia, X.; Wu, L.; Wang, R. Activation of KATP channels by H2S in rat insulin-secreting cells and the underlying mechanisms. J. Physiol. 2005, 569, 519-531. [CrossRef] [PubMed]

55. Yusuf, M.; Huat, B.T.K.; Hsu, A.; Whiteman, M.; Bhatia, M.; Moore, P.K. Streptozotocin-induced diabetes in the rat is associated with enhanced tissue hydrogen sulfide biosynthesis. Biochem. Biophys. Res. Commun. 2005, 333, 1146-1152. [CrossRef] 
56. Medeiros, J.V.R.; Bezerra, V.H.; Gomes, A.S.; Barbosa, A.L.R.; Lima, R.C.P.; Soares, P.M.G.; Brito, G.A.C.; Ribeiro, R.A.; Cunha, F.Q.; De Souza, M.H.L.P. Hydrogen sulfide prevents ethanol-induced gastric damage in mice: Role of ATP-sensitive potassium channels and capsaicin-sensitive primary afferent neurons. J. Pharmacol. Exp. Ther. 2009, 330, 764-770. [CrossRef]

57. Deplancke, B.; Gaskins, H.R. Hydrogen sulfide induces serum-independent cell cycle entry in nontransformed rat intestinal epithelial cells. FASEB J. 2003, 17, 1310-1312. [CrossRef] [PubMed]

58. Levine, J.; Ellis, C.J.; Furne, J.K.; Springfield, J.; Levitt, M.D. Fecal hydrogen sulfide production in ulcerative colitis. Am. J. Gastroenterol. 1998, 93, 83-87. [CrossRef]

59. Bogdándi, V.; Ida, T.; Sutton, T.R.; Bianco, C.; Ditrói, T.; Koster, G.; Henthorn, H.A.; Minnion, M.; Toscano, J.P.; van der Vliet, A.; et al. Speciation of reactive sulfur species and their reactions with alkylating agents: Do we have any clue about what is present inside the cell? Br. J. Pharmacol. 2019, 176, 646-670. [CrossRef] [PubMed]

60. Olson, K.R. H 2 S and polysulfide metabolism: Conventional and unconventional pathways. Biochem. Pharmacol. 2018, 149, 77-90. [CrossRef]

61. Beus, M.D.D.E.; Chung, J. Modification of cysteine 111 in $\mathrm{Cu} / \mathrm{Zn}$ superoxide dismutase results in altered spectroscopic and biophysical properties. Protein Sci. 2004, 1347-1355. [CrossRef] [PubMed]

62. Koike, S.; Ogasawara, Y.; Shibuya, N.; Kimura, H.; Ishii, K. Polysulfide exerts a protective effect against cytotoxicity caused by $\mathrm{t}$ -buthylhydroperoxide through Nrf2 signaling in neuroblastoma cells. FEBS Lett. 2013, 587, 3548-3555. [CrossRef]

63. Marcia, M.; Ermler, U.; Peng, G.; Michel, H. The structure of Aquifex aeolicus sulfide: Quinone oxidoreductase, a basis to understand sulfide detoxification and respiration. Proc. Natl. Acad. Sci. USA 2009, 106, 9625-9630. [CrossRef] [PubMed]

64. Hildebrandt, T.M.; Grieshaber, M.K. Three enzymatic activities catalyze the oxidation of sulfide to thiosulfate in mammalian and invertebrate mitochondria. FEBS J. 2008, 275, 3352-3361. [CrossRef]

65. Libiad, M.; Yadav, P.K.; Vitvitsky, V.; Martinov, M.; Banerjee, R. Organization of the human mitochondrial hydrogen sulfide oxidation pathway. J. Biol. Chem. 2014, 289, 30901-30910. [CrossRef] [PubMed]

66. Landry, A.P.; Ballou, D.P.; Banerjee, R. Hydrogen Sulfide Oxidation by Sulfide Quinone Oxidoreductase. ChemBioChem 2020, cbic.202000661. [CrossRef] [PubMed]

67. Makarov, S.V.; Horváth, A.K.; Makarova, A.S. Reactivity of Small Oxoacids of Sulfur. Molecules 2019, 24, 2768. [CrossRef]

68. Kumar, M.R.; Farmer, P.J. Chemical trapping and characterization of small oxoacids of sulfur (SOS) generated in aqueous oxidations of H2S. Redox Biol. 2018, 14, 485-491. [CrossRef]

69. Makarov, S.V.; Makarova, A.S.; Silaghi-Dumitrescu, R. Sulfoxylic and Thiosulfurous Acids and their Dialkoxy Derivatives. In Patai's Chemistry of Functional Groups, Peroxides; Liebman, J., Greer, A., Eds.; Wiley: Hoboken, NJ, USA, 2014; Volume 3, Part I; pp. 265-305.

70. Kabil, O.; Banerjee, R. Enzymology of H2S biogenesis, decay and signaling. Antioxid. Redox Signal. 2014, 20, 770-782. [CrossRef]

71. Hannibal, L.; Blom, H.J. Homocysteine and disease: Causal associations or epiphenomenons? Mol. Asp. Med. 2017, 53, 36-42. [CrossRef]

72. Gregory, J.F.; DeRatt, B.N.; Rios-Avila, L.; Ralat, M.; Stacpoole, P.W. Vitamin B6 nutritional status and cellular availability of pyridoxal 5'-phosphate govern the function of the transsulfuration pathway's canonical reactions and hydrogen sulfide production via side reactions. Biochimie 2016, 126, 21-26. [CrossRef]

73. Kožich, V.; Krijt, J.; Sokolová, J.; Melenovská, P.; Ješina, P.; Vozdek, R.; Majtán, T.; Kraus, J.P. Thioethers as markers of hydrogen sulfide production in homocystinurias. Biochimie 2016, 126, 14-20. [CrossRef]

74. Chen, X.; Jhee, K.H.; Kruger, W.D. Production of the neuromodulator H2S by cystathionine $\beta$-synthase via the condensation of cysteine and homocysteine. J. Biol. Chem. 2004, 279, 52082-52086. [CrossRef] [PubMed]

75. Meier, M.; Janosik, M.; Kery, V.; Kraus, J.P.; Burkhard, P. Structure of human cystathionine beta-synthase: A unique pyridoxal 5'-phosphate-dependent heme protein. EMBO J. 2001, 20, 3910-3916. [CrossRef]

76. Kabil, O.; Zhou, Y.; Banerjee, R. Human cystathionine $\beta$-synthase is a target for sumoylation. Biochemistry 2006, 45, 13528-13536. [CrossRef] [PubMed]

77. Bhattacharyya, S.; Saha, S.; Giri, K.; Lanza, I.R.; Nair, K.S.; Jennings, N.B.; Rodriguez-Aguayo, C.; Lopez-Berestein, G.; Basal, E.; Weaver, A.L.; et al. Cystathionine Beta-Synthase (CBS) Contributes to Advanced Ovarian Cancer Progression and Drug Resistance. PLoS ONE 2013, 8. [CrossRef] [PubMed]

78. Singh, S.; Padovani, D.; Leslie, R.A.; Chiku, T.; Banerjee, R. Relative contributions of cystathionine $\beta$-synthase and $\gamma$-cystathionase to H2S biogenesis via alternative trans-sulfuration reactions. J. Biol. Chem. 2009, 284, 22457-22466. [CrossRef] [PubMed]

79. Yamanishi, M.; Kabil, O.; Sen, S.; Banerjee, R. Structural insights into pathogenic mutations in heme-dependent cystathionine- $\beta$ synthase. J. Inorg. Biochem. 2006, 100, 1988-1995. [CrossRef]

80. Ereño-Orbea, J.; Majtan, T.; Oyenarte, I.; Kraus, J.P.; Martínez-Cruz, L.A. Structural basis of regulation and oligomerization of human cystathionine $\beta$-synthase, the central enzyme of transsulfuration. Proc. Natl. Acad. Sci. USA 2013, 110, E3790-E3799. [CrossRef]

81. Majtan, T.; Singh, L.R.; Wang, L.; Kruger, W.D.; Kraus, J.P. Active cystathionine $\beta$-synthase can be expressed in heme-free systems in the presence of metal-substituted porphyrins or a chemical chaperone. J. Biol. Chem. 2008, 283, 34588-34595. [CrossRef]

82. Taoka, S.; Banerjee, R. Characterization of NO binding to human cystathionine $\beta$-synthase: Possible implications of the effects of $\mathrm{CO}$ and NO binding to the human enzyme. J. Inorg. Biochem. 2001, 87, 245-251. [CrossRef] 
83. Jhee, K.H.; McPhie, P.; Miles, E.W. Domain architecture of the heme-independent yeast cystathionine $\beta$-synthase provides insights into mechanisms of catalysis and regulation. Biochemistry 2000, 39, 10548-10556. [CrossRef] [PubMed]

84. Hayes, L.C.; Plapp, F.V.; Tilzer, L.L. Activation of cystathionine synthase by adenosylmethionine and adenosylethionine. Biochem. Biophys. Res. Commun. 1975, 65, 258-264. [CrossRef]

85. Shafqat, N.; Muniz, J.R.C.; Pilka, E.S.; Papagrigoriou, E.; Von Delft, F.; Oppermann, U.; Yue, W.W. Insight into SAdenosylmethionine biosynthesis from the crystal structures of the human methionine adenosyltransferase catalytic and regulatory subunits. Biochem. J. 2013, 452, 27-36. [CrossRef] [PubMed]

86. Prudova, A.; Bauman, Z.; Braun, A.; Vitvitsky, V.; Lu, S.C.; Banerjee, R. S-adenosylmethionine stabilizes cystathionine $\beta$-synthase and modulates redox capacity. Proc. Natl. Acad. Sci. USA 2006, 103, 6489-6494. [CrossRef]

87. Majtan, T.; Liu, L.; Carpenter, J.F.; Kraus, J.P. Rescue of cystathionine $\beta$-synthase (CBS) mutants with chemical chaperones: Purification and characterization of eight CBS mutant enzymes. J. Biol. Chem. 2010, 285, 15866-15873. [CrossRef]

88. Vicente, J.B.; Colaço, H.G.; Sarti, P.; Leandro, P.; Giuffrè, A. S-adenosyl-L-methionine modulates CO and NO- binding to the human H2S-generating enzyme cystathionine $\beta$-synthase. J. Biol. Chem. 2016, 291, 572-581. [CrossRef]

89. Agrawal, N.; Banerjee, R. Human polycomb 2 protein is a SUMO E3 ligase and alleviates substrate-induced inhibition of cystathionine $\beta$-synthase sumoylation. PLoS ONE 2008, 3, 1-7. [CrossRef]

90. Diwakar, L.; Kenchappa, R.S.; Annepu, J.; Ravindranath, V. Downregulation of glutaredoxin but not glutathione loss leads to mitochondrial dysfunction in female mice CNS: Implications in excitotoxicity. Neurochem. Int. 2007, 51, 37-46. [CrossRef]

91. Hosoki, R.; Matsuki, N.; Kimura, H. The possible role of hydrogen sulfide as an endogenous smooth muscle relaxant in synergy with nitric oxide. Biochem. Biophys. Res. Commun. 1997, 237, 527-531. [CrossRef]

92. Kaneko, Y.; Kimura, Y.; Kimura, H.; Niki, I. L-cysteine inhibits insulin release from the pancreatic $\beta$-cell: Possible involvement of metabolic production of hydrogen sulfide, a novel gasotransmitter. Diabetes 2006, 55, 1391-1397. [CrossRef]

93. Patel, P.; Vatish, M.; Heptinstall, J.; Wang, R.; Carson, R.J. The endogenous production of hydrogen sulphide in intrauterine tissues. Reprod. Biol. Endocrinol. 2009, 7, 10. [CrossRef] [PubMed]

94. Vitvitsky, V.; Thomas, M.; Ghorpade, A.; Gendelman, H.E.; Banerjee, R. A functional transsulfuration pathway in the brain links to glutathione homeostasis. J. Biol. Chem. 2006, 281, 35785-35793. [CrossRef] [PubMed]

95. Li, L.; Bhatia, M.; Moore, P.K. Hydrogen sulphide-A novel mediator of inflammation? Curr. Opin. Pharmacol. 2006, 6, 125-129. [CrossRef] [PubMed]

96. Yang, G.; Wu, L.; Jiang, B.; Yang, W.; Qi, J.; Cao, K.; Meng, Q.; Mustafa, A.K.; Mu, W.; Zhang, S.; et al. H2S as a physiologic vasorelaxant: Hypertension in mice with deletion of cystathionine $\gamma$-lyase. Science 2008, 322, 587-590. [CrossRef] [PubMed]

97. Chiku, T.; Padovani, D.; Zhu, W.; Singh, S.; Vitvitsky, V.; Banerjee, R. H2S biogenesis by human cystathionine $\gamma$-lyase leads to the novel sulfur metabolites lanthionine and homolanthionine and is responsive to the grade of hyperhomocysteinemia. J. Biol. Chem. 2009, 284, 11601-11612. [CrossRef]

98. Yang, Q.; He, G.W. Imbalance of Homocysteine and H2S: Significance, Mechanisms, and Therapeutic Promise in Vascular Injury. Oxid. Med. Cell. Longev. 2019, 10, 1-11. [CrossRef]

99. Singh, S.; Banerjee, R. PLP-dependent H 2 S biogenesis. Biochim. Biophys. Acta Proteins Proteom. 2011, 1814, 1518-1527. [CrossRef]

100. Nagahara, N.; Nishino, T. Role of amino acid residues in the active site of rat liver mercaptopyruvate sulfurtransferase: cDNA cloning, overexpression, and site- directed mutagenesis. J. Biol. Chem. 1996, 271, 27395-27401. [CrossRef]

101. Shibuya, N.; Tanaka, M.; Yoshida, M.; Ogasawara, Y.; Togawa, T.; Ishii, K.; Kimura, H. 3-Mercaptopyruvate sulfurtransferase produces hydrogen sulfide and bound sulfane sulfur in the brain. Antioxid. Redox Signal. 2009, 11, 703-714. [CrossRef]

102. Vitvitsky, V.; Yadav, P.K.; Kurthen, A.; Banerjee, R. Sulfide oxidation by a noncanonical pathway in red blood cells generates thiosulfate and polysulfides. J. Biol. Chem. 2015, 290, 8310-8320. [CrossRef]

103. Fräsdorf, B.; Radon, C.; Leimkühler, S. Characterization and interaction studies of two isoforms of the dual localized 3mercaptopyruvate sulfurtransferase TUM1 from humans. J. Biol. Chem. 2014, 289, 34543-34556. [CrossRef] [PubMed]

104. Kimura, Y.; Goto, Y.I.; Kimura, H. Hydrogen sulfide increases glutathione production and suppresses oxidative stress in mitochondria. Antioxid. Redox Signal. 2010, 12, 1-13. [CrossRef] [PubMed]

105. Kimura, H. Hydrogen sulfide: Its production, release and functions. Amino Acids 2011, 41, 113-121. [CrossRef] [PubMed]

106. Yadav, P.K.; Vitvitsky, V.; Carballal, S.; Seravalli, J.; Banerjee, R. Thioredoxin regulates human mercaptopyruvate sulfurtransferase at physiologically-relevant concentrations. J. Biol. Chem. 2020, 295, 6299-6310. [CrossRef] [PubMed]

107. Uhlén, M.; Fagerberg, L.; Hallström, B.M.; Lindskog, C.; Oksvold, P.; Mardinoglu, A.; Sivertsson, Å.; Kampf, C.; Sjöstedt, E.; Asplund, A.; et al. Tissue-based map of the human proteome. Science 2015, 347. [CrossRef]

108. Kohl, J.B.; Mellis, A.; Schwarz, G. Homeostatic impact of sulfite and hydrogen sulfide on cysteine catabolism. Br. J. Pharmacol. 2019, 554-570. [CrossRef]

109. Benavides, G.A.; Squadrito, G.L.; Mills, R.W.; Patel, H.D.; Isbell, T.S.; Patel, R.P.; Darley-Usmar, V.M.; Doeller, J.E.; Kraus, D.W. Hydrogen sulfide mediates the vasoactivity of garlic. Proc. Natl. Acad. Sci. USA 2007, 104, 17977-17982. [CrossRef]

110. Searcy, D.G.; Lee, S.H. Sulfur reduction by human erythrocytes. J. Exp. Zool. 1998, 282, 310-322. [CrossRef]

111. Masi, A.D.; Ascenzi, P. H2S: A “Double face” molecule in health and disease. BioFactors 2013, 39, 186-196. [CrossRef]

112. Akaike, T.; Ida, T.; Wei, F.Y.; Nishida, M.; Kumagai, Y.; Alam, M.M.; Ihara, H.; Sawa, T.; Matsunaga, T.; Kasamatsu, S.; et al. Cysteinyl-tRNA synthetase governs cysteine polysulfidation and mitochondrial bioenergetics. Nat. Commun. 2017, 8, 1-15. [CrossRef] [PubMed] 
113. Dóka, É.; Pader, I.; Bíró, A.; Johansson, K.; Cheng, Q.; Ballagó, K.; Prigge, J.R.; Pastor-Flores, D.; Dick, T.P.; Schmidt, E.E.; et al. A novel persulfide detection method reveals protein persulfide- and polysulfide-reducing functions of thioredoxin and glutathione systems. Sci. Adv. 2016, 2, 1-14. [CrossRef] [PubMed]

114. Yang, J.; Minkler, P.; Grove, D.; Wang, R.; Willard, B.; Dweik, R.; Hine, C. Non-enzymatic hydrogen sulfide production from cysteine in blood is catalyzed by iron and vitamin B6. Commun. Biol. 2019, 2, 194. [CrossRef] [PubMed]

115. Bianco, C.L.; Savitsky, A.; Feelisch, M.; Cortese-Krott, M.M. Investigations on the role of hemoglobin in sulfide metabolism by intact human red blood cells. Biochem. Pharmacol. 2018, 149, 163-173. [CrossRef] [PubMed]

116. Cortese-Krott, M.M. Red blood cells as a "central hub" for sulfide bioactivity: Scavenging, metabolism, transport, and cross-talk with nitric oxide. Antioxid. Redox Signal. 2020, 33, 1332-1349. [CrossRef] [PubMed]

117. Guo, F.F.; Yu, T.C.; Hong, J.; Fang, J.Y. Emerging roles of hydrogen sulfide in inflammatory and neoplastic colonic diseases. Front. Physiol. 2016, 7, 1-8. [CrossRef]

118. Hale, V.L.; Jeraldo, P.; Mundy, M.; Yao, J.; Keeney, G.; Cheek, E.H.; Davidson, J.; Green, M.; Martinez, C.; Pettry, C.; et al. Synthesis of multi-omic data and community metabolic models reveals insights into the role of hydrogen sulfide in colon cancer. $H H S$ Public Access 2018, 68. [CrossRef]

119. Tomasova, L.; Konopelski, P.; Ufnal, M. Gut bacteria and hydrogen sulfide: The new old players in circulatory system homeostasis. Molecules 2016, 21, 1558. [CrossRef]

120. Seiflein, T.A.; Lawrence, J.G. Methionine-to-cysteine recycling in Klebsiella aerogenes. J. Bacteriol. 2001, 183, 336-346. [CrossRef]

121. Basic, A.; Blomqvist, M.; Dahlén, G.; Svensäter, G. The proteins of Fusobacterium spp. involved in hydrogen sulfide production from L-cysteine. BMC Microbiol. 2017, 17, 1-10. [CrossRef]

122. Shen, X.; Carlström, M.; Borniquel, S.; Jädert, C.; Kevil, C.G.; Lundberg, J.O. Microbial regulation of host hydrogen sulfide bioavailability and metabolism. Free Radic. Biol. Med. 2013, 60, 195-200. [CrossRef]

123. Ritz, N.L.; Burnett, B.J.; Setty, P.; Reinhart, K.M.; Wilson, M.R.; Alcock, J.; Singh, S.B.; Barton, L.L.; Lin, H.C. Sulfate-reducing bacteria impairs working memory in mice. Physiol. Behav. 2016, 157, 281-287. [CrossRef]

124. Linden, D.R. Hydrogen sulfide signaling in the gastrointestinal tract. Antioxid. Redox Signal. 2014, 20, 818-830. [CrossRef] [PubMed]

125. Linden, D.R.; Furne, J.; Stoltz, G.J.; Abdel-Rehim, M.S.; Levitt, M.D.; Szurszewski, J.H. Sulphide quinone reductase contributes to hydrogen sulphide metabolism in murine peripheral tissues but not in the CNS. Br. J. Pharmacol. 2012, 165, 2178-2190. [CrossRef] [PubMed]

126. Jackson, M.R.; Melideo, S.L.; Jorns, M.S. Human sulfide:Quinone oxidoreductase catalyzes the first step in hydrogen sulfide metabolism and produces a sulfane sulfur metabolite. Biochemistry 2012, 51, 6804-6815. [CrossRef]

127. Kabil, O.; Banerjee, R. Characterization of patient mutations in human persulfide dioxygenase (ETHE1) involved in H2S catabolism. J. Biol. Chem. 2012, 287, 44561-44667. [CrossRef]

128. Olson, K.R. Mitochondrial adaptations to utilize hydrogen sulfide for energy and signaling. J. Comp. Physiol. B Biochem. Syst. Environ. Physiol. 2012, 182, 881-897. [CrossRef] [PubMed]

129. Schrader, N.; Fischer, K.; Theis, K.; Mendel, R.R.; Schwarz, G.; Kisker, C. The crystal structure of plant sulfite oxidase provides insights into sulfite oxidation in plants and animals. Structure 2003, 11, 1251-1263. [CrossRef] [PubMed]

130. Schwarz, G.; Mendel, R.R.; Ribbe, M.W. Molybdenum cofactors, enzymes and pathways. Nature 2009, 460, 839-847. [CrossRef]

131. Friederich, M.W.; Elias, A.F.; Kuster, A.; Laugwitz, L.; Larson, A.A.; Landry, A.P.; Ellwood-Digel, L.; Mirsky, D.M.; Dimmock, D.; Haven, J.; et al. Pathogenic variants in SQOR encoding sulfide:quinone oxidoreductase are a potentially treatable cause of Leigh disease. J. Inherit. Metab. Dis. 2020, 43, 1-13. [CrossRef]

132. Aminlari, M.; Gilanpour, H. Comparative studies on the distribution of rhodanese in different tissues of domestic animals. Comp Biochem. Physiol. Part B Biochem. 1991, 99, 673-677. [CrossRef]

133. Furne, J.; Springfield, J.; Koenig, T.; DeMaster, E.; Levitt, M.D. Oxidation of hydrogen sulfide and methanethiol to thiosulfate by rat tissues: A specialized function of the colonic mucosa. Biochem. Pharmacol. 2001, 62, 255-259. [CrossRef]

134. Libiad, M.; Sriraman, A.; Banerjee, R. Polymorphic variants of human rhodanese exhibit differences in thermal stability and sulfur transfer kinetics. J. Biol. Chem. 2015, 290, 23579-23588. [CrossRef] [PubMed]

135. Rizzi, M.; Wittenberg, J.B.; Coda, A.; Fasano, M.; Ascenzi, P.; Bolognesi, M. Structure of the sulfide-reactive hemoglobin from the clam Lucina pectinata: Crystallographic analysis at 1.5 Å resolution. J. Mol. Biol. 1994, 244, 86-99. [CrossRef] [PubMed]

136. Ascenzi, P.; Bellelli, A.; Coletta, M.; Colosimo, A.; Falcioni, G.; Giacometti, G.M.; Ippoliti, R.; Zolla, L.; Giardina, B. Multiple strategies for $\mathrm{O} 2$ transport: From simplicity to complexity. IUBMB Life 2007, 59, 600-616. [CrossRef] [PubMed]

137. Wang, R. Physiological implications of hydrogen sulfide: A whiff exploration that blossomed. Physiol. Rev. 2012, 92, 791-896. [CrossRef] [PubMed]

138. Beauchamp, R.O.; Bus, J.S.; Popp, J.A.; Boreiko, C.J.; Andjelkovich, D.A.; Leber, P. A critical review of the literature on hydrogen sulfide toxicity. Crit. Rev. Toxicol. 1984, 13, 25-97. [CrossRef]

139. Ogasawara, Y.; Isoda, S.; Tanabe, S. Tissue and Subcellular Distribution of Bound and Acid-Labile Sulfur, and the Enzymic Capacity for Sulfide Production in the Rat. Biol. Pharm. Bull. 1994, 17, 1535-1542. [CrossRef] [PubMed]

140. Toohey, J.I. Sulphane sulphur in biological systems: A possible regulatory role. Biochem. J. 1989, 264, 625-632. [CrossRef]

141. Yang, G.; Zhao, K.; Ju, Y.; Mani, S.; Cao, Q.; Puukila, S.; Khaper, N.; Wu, L.; Wang, R. Hydrogen sulfide protects against cellular senescence via s-sulfhydration of keap1 and activation of Nrf2. Antioxid. Redox Signal. 2013, 18, 1906-1919. [CrossRef] 
142. Hourihan, J.M.; Kenna, J.G.; Hayes, J.D. The gasotransmitter hydrogen sulfide induces Nrf2-target genes by inactivating the keap1 ubiquitin ligase substrate adaptor through formation of a disulfide bond between Cys-226 and Cys-613. Antioxid. Redox Signal. 2013, 19, 465-481. [CrossRef]

143. Xie, L.; Gu, Y.; Wen, M.; Zhao, S.; Wang, W.; Ma, Y.; Meng, G.; Han, Y.; Wang, Y.; Liu, G.; et al. Hydrogen sulfide induces Keap1 S-sulfhydration and suppresses diabetes-accelerated atherosclerosis via Nrf2 activation. Diabetes 2016, 65, 3171-3184. [CrossRef] [PubMed]

144. Fu, L.; Liu, K.; He, J.; Tian, C.; Yu, X.; Yang, J. Direct Proteomic Mapping of Cysteine Persulfidation. Antioxid. Redox Signal. 2020, 33, 1061-1076. [CrossRef] [PubMed]

145. Benchoam, D.; Semelak, J.A.; Cuevasanta, E.; Mastrogiovanni, M.; Grassano, J.S.; Ferrer-Sueta, G.; Zeida, A.; Trujillo, M.; Möller, M.N.; Estrin, D.A.; et al. Acidity and nucleophilic reactivity of glutathione persulfide. J. Biol. Chem. 2020, $295,15466-15481$. [CrossRef]

146. Filipovic, M.R.; Zivanovic, J.; Alvarez, B.; Banerjee, R. Chemical Biology of H2S Signaling through Persulfidation. Chem. Rev. 2018, 118, 1253-1337. [CrossRef]

147. Paul, B.D.; Snyder, S.H.; Kashfi, K. Effects of hydrogen sulfide on mitochondrial function and cellular bioenergetics. Redox Biol. 2021, 38. [CrossRef] [PubMed]

148. Fukuto, J.M.; Vega, V.S.; Works, C.; Lin, J. The chemical biology of hydrogen sulfide and related hydropersulfides: Interactions with biologically relevant metals and metalloproteins. Curr. Opin. Chem. Biol. 2020, 55, 52-58. [CrossRef] [PubMed]

149. Nicholls, P.; Kim, J.K. Sulphide as an inhibitor and electron donor for the cytochrome c oxidase system. Can. J. Biochem. 1982, 60, 613-623. [CrossRef]

150. Scammahorn, J.J.; Nguyen, I.T.N.; Bos, E.M.; van Goor, H.; Joles, J.A. Fighting oxidative stress with sulfur: Hydrogen sulfide in the renal and cardiovascular systems. Antioxidants 2021, 10, 373. [CrossRef]

151. Olson, K.R.; Gao, Y.; Briggs, A.; Devireddy, M.; Iovino, N.A.; Licursi, M.; Skora, N.C.; Whelan, J.; Villa, B.P.; Straub, K.D. 'Antioxidant' berries, anthocyanins, resveratrol and rosmarinic acid oxidize hydrogen sulfide to polysulfides and thiosulfate: A novel mechanism underlying their biological actions. Free Radic. Biol. Med. 2021, 165, 67-78. [CrossRef]

152. Xie, Z.Z.; Liu, Y.; Bian, J.S. Hydrogen Sulfide and Cellular Redox Homeostasis. Oxidative Med. Cell. Longev. 2016, 2016. [CrossRef]

153. Casin, K.M.; Calvert, J.W. Harnessing the benefits of endogenous hydrogen sulfide to reduce cardiovascular disease. Antioxidants 2021, 10, 383. [CrossRef] [PubMed]

154. Lodhi, A.H.; Ahmad, F.U.D.; Furwa, K.; Madni, A. Role of oxidative stress and reduced endogenous hydrogen sulfide in diabetic nephropathy. Drug Des. Dev. Ther. 2021, 15, 1031-1043. [CrossRef]

155. Dillon, K.M.; Matson, J.B. A Review of Chemical Tools for Studying Small Molecule Persulfides: Detection and Delivery. ACS Chem. Biol. 2021. [CrossRef] [PubMed]

156. Dulac, M.; Melet, A.; Galardon, E. Reversible Detection and Quantification of Hydrogen Sulfide by Fluorescence Using the Hemoglobin i from Lucina pectinata. ACS Sens. 2018, 3, 2138-2144. [CrossRef]

157. Guenther, E.A.; Johnson, K.S.; Coale, K.H. Direct ultraviolet spectrophotometric determination of total sulfide and iodide in natural waters. Anal. Chem. 2001, 73, 3481-3487. [CrossRef] [PubMed]

158. Boffi, A.; Rizzi, M.; Monacelli, F.; Ascenzi, P. Determination of H2S solubility via the reaction with ferric hemoglobin I from the bivalve mollusc Lucina pectinata. Biochim. Biophys. Acta Gen. Subj. 2000, 1523, 206-208. [CrossRef]

159. Budd, M.S.; Bewick, H.A. Photometric Determination of Sulfide and Reducible Sulfur in Alkalies. Anal. Chem. 1952, 24, 1536-1540. [CrossRef]

160. Sheppard, S.E.; Geddes, A.L. Effect of Solvents upon the Absorption Spectra of Dyes. V. Water as Solvent: Quantitative Examination of the Dimerization Hypothesis. J. Am. Chem. Soc. 1944, 66, 2003-2009. [CrossRef]

161. Pomeroy, R. The determination of sulphides in sewage. Sew. Work. J. 1936, 8, 572-591.

162. Kovatsis, A.; Tsougas, M. Determination of hydrogen sulfide (H2S) in environment by indirect atomic absorption spectroscopy. Bull. Environ. Contam. Toxicol. 1976, 15, 412-420. [CrossRef]

163. Fischer, E. Bildung von Methylenblau als Reaktion auf Schwefelwasserstoff. Ber. Dtsch. Chem. Ges. 1883, 16, 2234-2236. [CrossRef]

164. Sakurai, H.; Lien, S.; Pietro, A.S. Determination of acid-labile sulfide and zero-valence sulfur in subchloroplast particles in the presence of sodium dodecyl sulfate. Anal. Biochem. 1982, 119, 372-377. [CrossRef]

165. Mylon, S.E.; Benoit, G. Subnanomolar detection of acid-labile sulfides by the classical methylene blue method coupled to HPLC. Environ. Sci. Technol. 2001, 35, 4544-4548. [CrossRef] [PubMed]

166. Haddad, P.R.; Heckenberg, A.L. Trace determination of sulfide by reversed-phase ion- interaction chromatography using pre-column derivatization. J. Chromatogr. 1988, 447, 415-420. [CrossRef]

167. Small, J.M.; Hintelmann, H. Methylene blue derivatization then LC-MS analysis for measurement of trace levels of sulfide in aquatic samples. Anal. Bioanal. Chem. 2007, 387, 2881-2886. [CrossRef] [PubMed]

168. Shen, X.; Pattillo, C.B.; Pardue, S.; Bir, S.C.; Wang, R.; Kevil, C.G. Measurement of plasma hydrogen sulfide in vivo and in vitro. Free Radic. Biol. Med. 2011, 50, 1021-1031. [CrossRef]

169. Kraus, D.; Wittenberg, J.B. Hemoglobins of the Lucina pectinatu/Bacteria Symbiosis. J. Biol. Chem. 1990, 265, 16043-16053. [CrossRef] 
170. Collazo, E.; Pietri, R.; De Jesús, W.; Ramos, C.; Del Toro, A.; León, R.G.; Cadilla, C.L.; López-Garriga, J. Functional Characterization of the Purified Holo Form of Hemoglobin I from Lucina pectinata Overexpressed in Escherichia coli. Protein J. 2004, $23,239-245$. [CrossRef]

171. Ramos-Alvarez, C.; Yoo, B.K.; Pietri, R.; Lamarre, I.; Martin, J.L.; Lopez-Garriga, J.; Negrerie, M. Reactivity and dynamics of $\mathrm{H}_{2} \mathrm{~S}$, $\mathrm{NO}$, and $\mathrm{O}_{2}$ interacting with hemoglobins from Lucina pectinata. Biochemistry 2013, 52, 7007-7021. [CrossRef]

172. León, R.G.; Munier-Lehmann, H.; Barzu, O.; Baudin-Creuza, V.; Pietri, R.; López-Garriga, J.; Cadilla, C.L. High-level production of recombinant sulfide-reactive hemoglobin I from Lucina pectinata in Escherichia coli: High yields of fully functional holoprotein synthesis in the BLi5 E. coli strain. Protein Expr. Purif. 2004, 38, 184-195. [CrossRef]

173. Westley, A.M.; Westley, J. Biological sulfane sulfur. Anal. Biochem. 1991, 195, 63-67. [CrossRef]

174. Savage, J.C.; Gould, D.H. Determination of sulfide in brain tissue and rumen fluid by ion-interaction reversed-phase highperformance liquid chromatography. J. Chromatogr. B Biomed. Sci. Appl. 1990, 526, 540-545. [CrossRef]

175. Ogasawara, Y.; Ishii, K.; Togawa, T.; Tanabe, S. Determination of trace amounts of sulphide in human red blood cells by highperformance liquid chromatography with fluorimetric detection after derivatization with p-phenylenediamine and iron(III). Analyst 1991, 116, 1359-1363. [CrossRef]

176. Sutton, T.R.; Minnion, M.; Barbarino, F.; Koster, G.; Fernandez, B.O.; Cumpstey, A.F.; Wischmann, P.; Madhani, M.; Frenneaux, M.P.; Postle, A.D.; et al. A robust and versatile mass spectrometry platform for comprehensive assessment of the thiol redox metabolome. Redox Biol. 2018, 16, 359-380. [CrossRef]

177. Liu, C.; Pan, J.; Li, S.; Zhao, Y.; Wu, L.Y.; Berkman, C.E.; Whorton, A.R.; Xian, M. Capture and visualization of hydrogen sulfide by a fluorescent probe. Angew. Chem. Int. Ed. 2011, 50, 10327-10329. [CrossRef]

178. Peng, H.; Cheng, Y.; Dai, C.; King, A.L.; Predmore, B.L.; Lefer, D.J.; Wang, B. A fluorescent probe for fast and quantitative detection of hydrogen sulfide in blood. Angew. Chem. Int. Ed. 2011, 50, 9672-9675. [CrossRef] [PubMed]

179. Thorson, M.K.; Majtan, T.; Kraus, J.P.; Barrios, A.M. Identification of Cystathionine b -Synthase Inhibitors Using a Hydrogen Sulfide Selective Probe. Angew. Chem. 2013, 52, 4641-4644. [CrossRef] [PubMed]

180. Kerkovius, J.K.; Menard, F. A Practical Synthesis of 6,8-Difluoro-7-hydroxycoumarin Derivatives for Fluorescence Applications. Synth. 2016, 48, 1622-1629. [CrossRef]

181. Tóth, I.; Solymosi, P.; Szabó, Z. Application of a sulphide-selective electrode in the absence of a pH-buffer. Talanta 1988, 35, 783-788. [CrossRef]

182. Whitfield, N.L.; Kreimier, E.L.; Verdial, F.C.; Skovgaard, N.; Olson, K.R. Reappraisal of $\mathrm{H}_{2} \mathrm{~S}$ / sulfide concentration in vertebrate blood and its potential significance in ischemic preconditioning and vascular signaling. Am. J. Physiol. Regul. Integr. Comp. Physiol. 2008, 294, 1930-1937. [CrossRef]

183. Searcy, D.G.; Peterson, M.A. Hydrogen sulfide consumption measured at low steady state concentrations using a sulfidostat. Anal. Biochem. 2004, 324, 269-275. [CrossRef]

184. Koenitzer, J.R.; Isbell, T.S.; Patel, H.D.; Benavides, G.A.; Dickinson, D.A.; Patel, R.P.; Darley-Usmar, V.M.; Lancaster, J.R.; Doeller J.E.; Kraus, D.W. Hydrogen sulfide mediates vasoactivity in an $\mathrm{O}_{2}$-dependent manner. Am. J. Physiol. Heart Circ. Physiol. 2007, 292, 1953-1960. [CrossRef]

185. Faccenda, A.; Wang, J.; Mutus, B. Polydimethylsiloxane permeability-based method for the continuous and specific detection of hydrogen sulfide. Anal. Chem. 2012, 84, 5243-5249. [CrossRef] [PubMed]

186. Krijt, J.; Kopecká, J.; Hnízda, A.; Moat, S.; Kluijtmans, L.A.J.; Mayne, P.; Kožich, V. Determination of cystathionine beta-synthase activity in human plasma by LC-MS/MS: Potential use in diagnosis of CBS deficiency. J. Inherit. Metab. Dis. 2011, 34, 49-55. [CrossRef]

187. Alcaide, P.; Krijt, J.; Ruiz-Sala, P.; Ješina, P.; Ugarte, M.; Kožich, V.; Merinero, B. Enzymatic diagnosis of homocystinuria by determination of cystathionine-ß-synthase activity in plasma using LC-MS/MS. Clin. Chim. Acta 2015, 438, 261-265. [CrossRef]

188. Mubeen, S.; Zhang, T.; Chartuprayoon, N.; Rheem, Y.; Mulchandani, A.; Myung, N.V.; Deshusses, M.A. Sensitive detection of H2S using gold nanoparticle decorated single-walled carbon nanotubes. Anal. Chem. 2010, 82, 250-257. [CrossRef]

189. Morava, E.; Rahman, S.; Peters, V.; Baumgartner, M.R.; Patterson, M.; Zschocke, J. Quo vadis: The re-definition of "inborn metabolic diseases". J. Inherit. Metab. Dis. 2015, 38, 1003-1006. [CrossRef] [PubMed]

190. Zschocke, J. SSIEM Classification of Inborn Errors of Metabolism. In Physician's Guide to the Diagnosis, Treatment, and Follow-Up of Inherited Metabolic Diseases; Springer: Berlin/Heidelberg, Germany, 2014; pp. 817-830.

191. CBS[gene]—ClinVar-NCBI. Available online: https://www.ncbi.nlm.nih.gov/clinvar/?term=CBS\%5Bgene $\% 5 \mathrm{D}$ (accessed on 12 May 2020).

192. Kraus, J.P.; Janosǐk, M.; Kožich, V.; Mandell, R.; Shih, V.; Sperandeo, M.P.; Sebastio, G.; De Franchis, R.; Andria, G.; Kluijtmans, L.A.J.; et al. Cystathionine $\beta$-synthase mutations in homocystinuria. Hum. Mutat. 1999, 13, 362-375. [CrossRef]

193. Vicente, J.B.; Colaço, H.G.; Malagrinò, F.; Santo, P.E.; Gutierres, A.; Bandeiras, T.M.; Leandro, P.; Brito, J.A.; Giuffrè, A. A Clinically Relevant Variant of the Human Hydrogen Sulfide-Synthesizing Enzyme Cystathionine $\beta$-Synthase: Increased CO Reactivity as a Novel Molecular Mechanism of Pathogenicity? Oxidative Med. Cell. Longev. 2017, 20178. [CrossRef]

194. DeRatt, B.N.; Ralat, M.A.; Kabil, O.; Chi, Y.-Y.; Banerjee, R.; Gregory, J.F. Vitamin B-6 Restriction Reduces the Production of Hydrogen Sulfide and its Biomarkers by the Transsulfuration Pathway in Cultured Human Hepatoma Cells. J. Nutr. 2014, 144, 1501-1508. [CrossRef] 
195. Han, M.; Liu, D.; Qiu, J.; Yuan, H.; Hu, Q.; Xue, H.; Li, T.; Ma, W.W.; Zhang, Q.; Li, G.; et al. Evaluation of $\mathrm{H}_{2} \mathrm{~S}-\mathrm{producing}$ enzymes in cerebrospinal fluid and its relationship with interleukin-6 and neurologic deficits in subarachnoid hemorrhage. Biomed. Pharmacother. 2020, 123, 109722. [CrossRef]

196. Banerjee, R.; Chiku, T.; Kabil, O.; Libiad, M.; Motl, N.; Yadav, P.K. Assay Methods for $\mathrm{H}_{2} \mathrm{~S}$ Biogenesis and Catabolism Enzymes. Methods Enzym. 2015, 554, 189-200. [CrossRef]

197. Tiranti, V.; Viscomi, C.; Hildebrandt, T.; Di Meo, I.; Mineri, R.; Tiveron, C.; Levitt, M.D.; Prelle, A.; Fagiolari, G.; Rimoldi, M.; et al. Loss of ETHE1, a mitochondrial dioxygenase, causes fatal sulfide toxicity in ethylmalonic encephalopathy. Nat. Med. 2009, 15, 200-205. [CrossRef] [PubMed]

198. Watanabe, M.; Osada, J.; Aratani, Y.; Kluckman, K.; Reddick, R.; Malinow, M.R.; Maeda, N. Mice deficient in cystathionine $\beta$-synthase: Animal models for mild and severe homocyst(e)inemia. Proc. Natl. Acad. Sci. USA 1995, 92, 1585-1589. [CrossRef] [PubMed]

199. Gupta, S.; Wang, L.; Slifker, M.J.; Cai, K.Q.; Maclean, K.N.; Wasek, B.; Bottiglieri, T.; Kruger, W.D. Analysis of differential neonatal lethality in cystathionine $\beta$-synthase deficient mouse models using metabolic profiling. FASEB J. 2021, 35. [CrossRef] [PubMed]

200. Jensen, K.K.; Geoghagen, N.S.; Jin, L.; Holt, T.G.; Luo, Q.; Malkowitz, L.; Ni, W.; Quan, S.; Waters, M.G.; Zhang, A.; et al. Pharmacological activation and genetic manipulation of cystathionine beta-synthase alter circulating levels of homocysteine and hydrogen sulfide in mice. Eur. J. Pharmacol. 2011, 650, 86-93. [CrossRef]

201. George, A.K.; Homme, R.P.; Majumder, A.; Laha, A.; Metreveli, N.; Sandhu, H.S.; Tyagi, S.C.; Singh, M. Hydrogen sulfide intervention in cystathionine- $\beta$-synthase mutant mouse helps restore ocular homeostasis. Int. J. Ophthalmol. 2019, 12, 754-764. [CrossRef]

202. Majtan, T.; Krijt, J.; Sokolová, J.; Křížková, M.; Ralat, M.A.; Kent, J.; Gregory, J.F.; Kožich, V.; Kraus, J.P. Biogenesis of Hydrogen Sulfide and Thioethers by Cystathionine Beta-Synthase. Antioxid. Redox Signal. 2018, 28, 311-323. [CrossRef] [PubMed]

203. Leigh, J.; Juriasingani, S.; Akbari, M.; Shao, P.; Saha, M.N.; Lobb, I.; Bachtler, M.; Fernandez, B.; Qian, Z.; Van Goor, H.; et al. Endogenous H2S production deficiencies lead to impaired renal erythropoietin production. Can. Urol. Assoc. J. 2019, 13, E210-E219. [CrossRef] [PubMed]

204. Roman, H.B.; Hirschberger, L.L.; Krijt, J.; Valli, A.; Kožich, V.; Stipanuk, M.H. The cysteine dioxgenase knockout mouse: Altered cysteine metabolism in nonhepatic tissues leads to excess $\mathrm{H}_{2} \mathrm{~S} / \mathrm{HS}$ - production and evidence of pancreatic and lung toxicity. Antioxid. Redox Signal. 2013, 19, 1321-1336. [CrossRef] [PubMed]

205. Linden, D.R.; Sha, L.; Mazzone, A.; Stoltz, G.J.; Bernard, C.E.; Furne, J.K.; Levitt, M.D.; Farrugia, G.; Szurszewski, J.H. Production of the gaseous signal molecule hydrogen sulfide in mouse tissues. J. Neurochem. 2008, 106, 1577-1585. [CrossRef] [PubMed]

206. Mendes, M.I.S.; Colaço, H.G.; Smith, D.E.C.; Ramos, R.J.J.F.; Pop, A.; Van Dooren, S.J.M.; Tavares De Almeida, I.; Kluijtmans, L.A.J.; Janssen, M.C.H.; Rivera, I.; et al. Reduced response of Cystathionine Beta-Synthase (CBS) to S-Adenosylmethionine (SAM): Identification and functional analysis of CBS gene mutations in Homocystinuria patients. J. Inherit. Metab. Dis. 2014, 37, $245-254$. [CrossRef] [PubMed] 